\title{
Facility Effluent Monitoring Plan for the 222-S Laboratory
}

\author{
J. M. Nickels \\ G. J. Warwick
}

Date Published

November 1992

Prepared for the U.S. Department of Energy Office of Environmental Restoration and Environmental Management

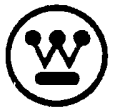




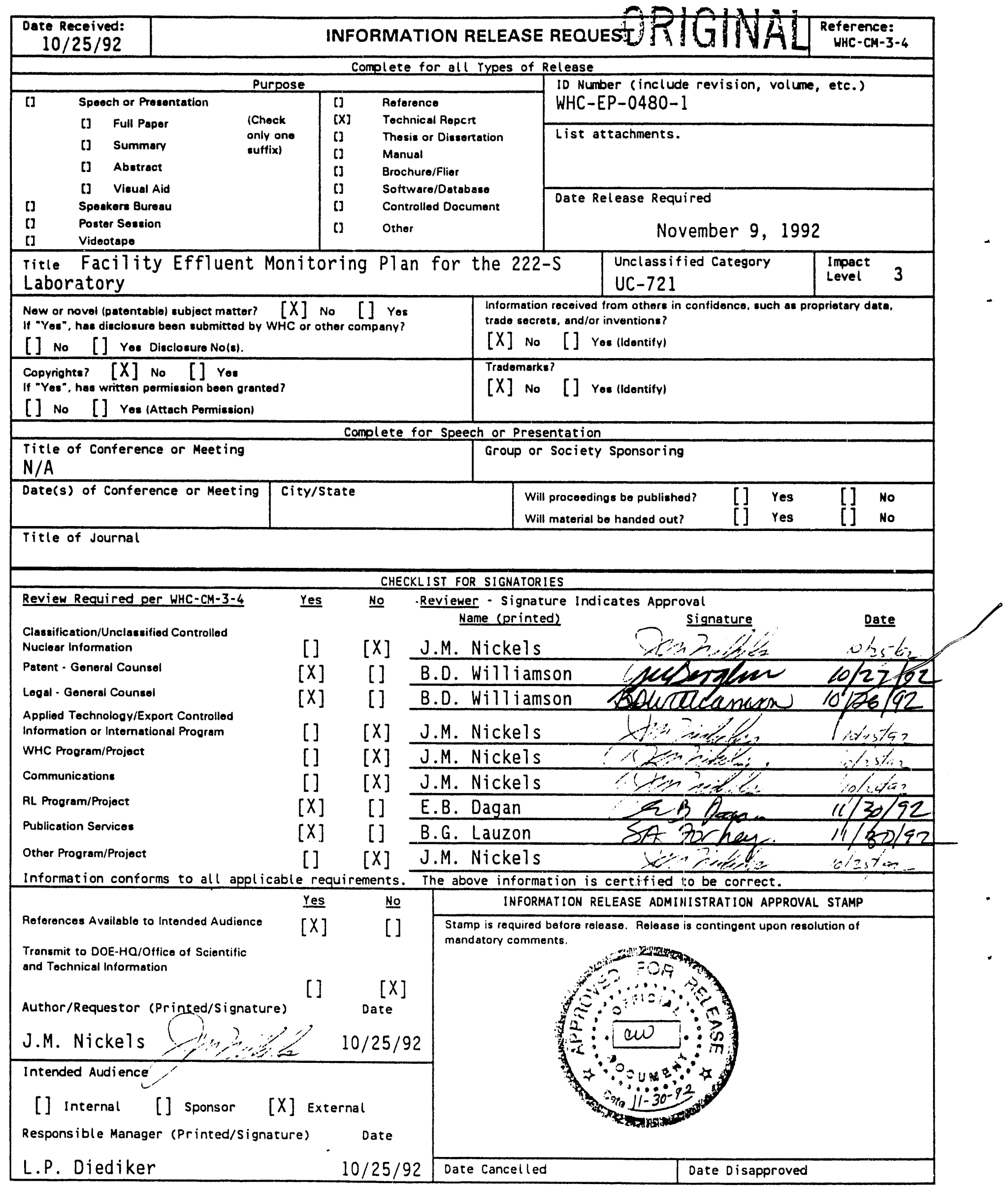


WHC-EP-0480-1

WESTINGHOUSE HANFORD COMPANY APPROVAL PAGE

Document Title: Facility Effluent Monitoring Plan for 222-S Laboratory

Prepared by: G. JWharwick, Engineer
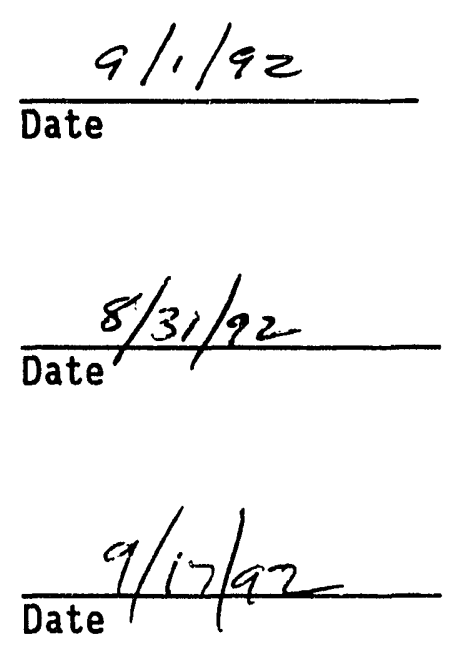

R. P. Marshall, Jr., Manager
$222-S$ Laboratory Operations

Date

$\frac{01,7^{\prime}+2}{0 \text { ate }}$

S. L. Bree, Manager

Laboratory Engineering

Approved by:
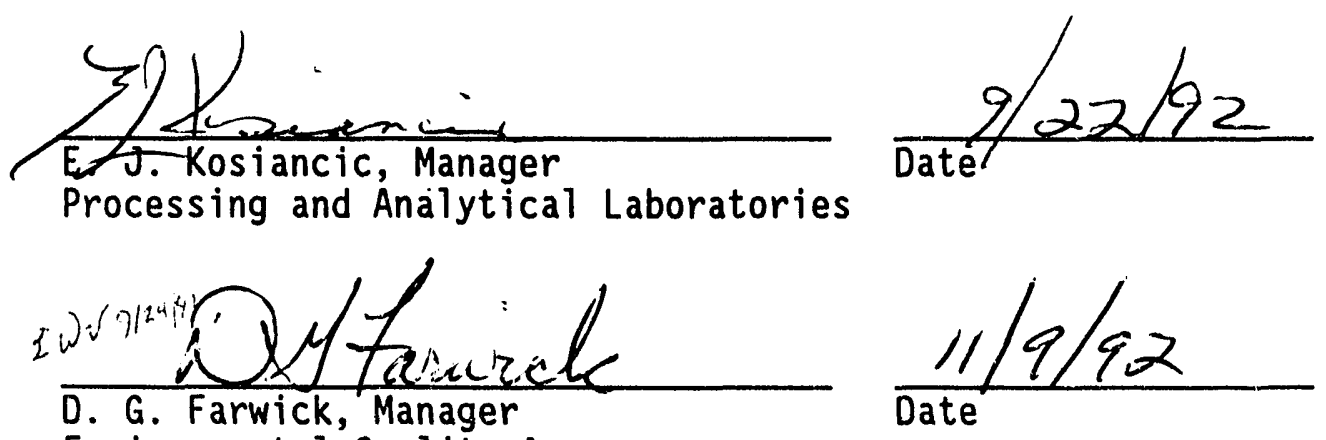

D. G. Farwick, Manager

Environmental Quality Assurance

Approved by:

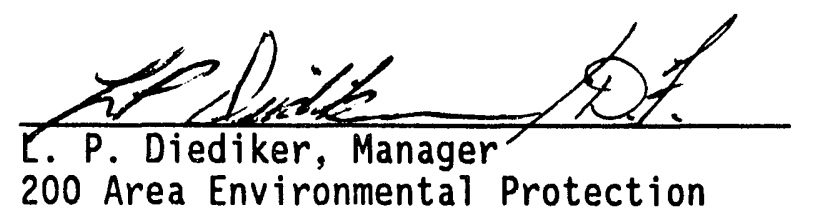

200 Area Environmental Protection

$4 \cdot 23-42$

Date

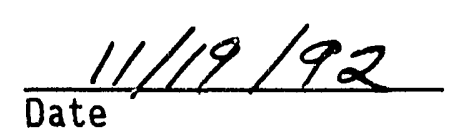

R. J. Lantern, Tanager

Regulatory Analys is 
WHC-EP-0480-1

This page intentionally left blank. 
WHC-EP-0480-1

\section{FACILITY EFFLUENT MONITORING PLAN FOR THE 222-S LABORATORY}

\section{J. M. Nickels}

\section{ABSTRACT}

A facility effluent monitoring plan is required by the U.S. Department of Energy in DOE Order 5400.1* for any operations that involve hazardous materials and radioactive substances that could impact employee or public safety or the environment. A facility effluent monitoring plan determination was performed during Calendar Year 1991 and the evaluation requires the need for a facility effluent monitoring plan. This document is prepared using the specific guidelines identified in A Guide for Preparing Hanford Site Facility Effluent Monitoring Plans, WHC-EP-0438-1**. This facility effluent monitoring plan assesses effluent monitoring systems and evaluates whether they are adequate to ensure the public health and safety as specified in applicable Federal, State, and local requirements.

This facility effluent monitoring plan shall ensure long-range integrity of the effluent monitoring systems by requiring an update whenever a new process or operation introduces new hazardous materials or significant radioactive materials. This document must be reviewed annually even if there are no operational changes, and it must be updated, as a minimum, every three years.

*General Environmental Protection Program, DOE Order 5400.1, U.S. Department of Energy, Washington, D.C., 1988.

**A Guide for Preparing Hanford Site Facility Effluent Monitoring Plans, WHC-EP-0438-1, Westinghouse Hanford Company, Richland, Washington, 1992. 


\section{WHC-EP-0480-1}

This facility effluent monitoring plan has been revised to include U.S. Department of Energy/Westinghouse Hanford Company Regulatory Analysis comments, procedure changes (revisions), and improved U.S. Environmental Protection Agency National Emission Standards for Hazardous Air Pollutants* point-by-point evaluation.

* National Emission Standards for Hazardous Air Pollutants (NESHAP) Title 40, Code of Federal Regulations Part 61, as amended, U.S. Environmental Protection Agency, Washington, D.C., 1987. 
WHC-EP-0480-1

\section{CONTENTS}

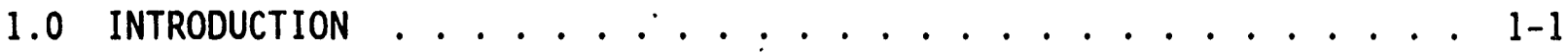

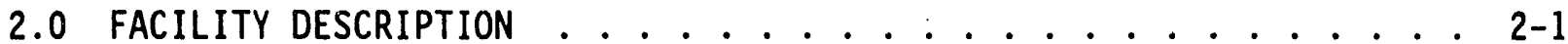

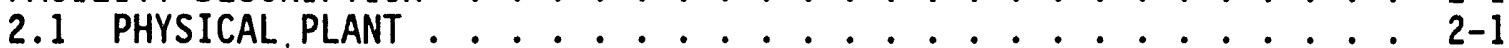

2.2 PROCESS DESCRIPTION . . . . . . . . . . . . 2-6

2.2.1 Past Practices ............... 2-6

2.2.2 Current Practices .............. 2-6

2.3 POTENTIAL SOURCE TERMS ............... . 2-7

2.3.1 The 222-SA Laboratory ............... 2-7

2.3.2 The 222-S Laboratory ................ 2-7

2.3.3 The 207-SL Retention Basins ........... 2-8

2.3.4 The 219-S Waste Handling Facility.......... 2-10

2.3.5 Nitric Acid Tanks ............... 2-11

2.3.6 Nonhazardous Sol id Low-Level Waste . . . . . . . . 2-11

2.3.7 Mixed Solid Waste - Lead Waste . . . . . . . . . . . 2-12

2.3 .8 Cold Wastes . . . . . . . . . . . . . . . 2-12

2.3.9 Mixed Liquid Waste - Organic . . . . . . . . . 2-13

2.3.10 Mixed Liquid Waste - Aqueous . . . . . . . . . . 2-13

2.3.11 Mixed Solid Waste - Laboratory Chemicals . . . . . 2-13

2.3.12 Waste Aerosol Cans ............. . 2-14

2.3.13 Transuranic Solid Waste . . . . . . . . . . . . 2-14

2.3.14 Waste Asbestos ............ 2-14

2.3.15 The 296-S-21 Stack Fan Emergency Diesel Tank ... . . 2-15

2.3.16 The 218-W-7 Dry Waste Vault . . . . . . . . . 2-15

3.0 APPLICABLE REGULATIONS .............. . . . . . . . .

3.1 REgULATIONS PERTAINING TO EFFLUENT RELEASES ........ 3-1

3.2 REGULATIONS PERTAINING TO MONITORING REQUIREMENTS

AT U.S. DEPARTMENT OF ENERGY FACILITIES . . . . . . . . . 3-4

3.2.1 U.S. Department of Energy Facility Effluent $\ldots . . . . .3-5$

3.2.2 Airborne Effluents . . . . . . . . . . . . 3-6

3.2.3 Liquid Effluents . . . . . . . . . . . . . . . 3-8

3.2.4 Hazardous Mixed Wastes . . . . . . . . . . . . . . . 3-10

3.3 STANDARDS/REFERENCES . . . . . . . . . . . . . . 3-10

3.4 WESTINGHOUSE HANFORD EFFLUENT MONITORING REQUIREMENTS ... . 3-11

3.5 FACILITY REQUIREMENTS FOR ORGANIC EMISSION STANDARDS . . . . . 3-11

4.0 IDENTIFICATION AND CHARACTERIZATION OF EFFLUENT STREAMS . . . . . . 4-1

4.1 LIQUID EFFLUENTS . . . . . . . . . . . . . 4-1

4.1.1 222-S Laboratory Wastewater . . . . . . . . . . . 4 4-1

4.1.2 222-SA Laboratory Wastewater ............ 4-4

4.1.3 291-S Stack Fan House Cooling Water. . . . . . . . 4 4-4

4.1.4 The 219-S Waste Handling Facility. . . . . . . . . 4-5

4.2 AIRBORNE EMISSIONS . . . . . . . . . . . . . . . . . 4-5

4.2.1 The 296-S-21 Stack . . . . . . . . . . . . 4-5

4.2.2 The $296-$ S-16 Stack . . . . . . . . . . . 4-8

4.2.3 The 296-S-23 Stack ... . . . . . . . . . . . 4-8

4.2.4 The Vacuum Air Sample Pumps Stack . . . . . . . . . . 4-9

4.2.5 The 222-SA Stack ............... 4- . 4

4.2.6 The Nitric Acid Tank Vent . . . . . . . . . . . . 4-10 
WHC-EP-0480-1

CONTENTS (continued)

4.3 SUMMARY ...................... . . . . . . . . . . .

5.0 EFFLUENT POINT OF DISCHARGE DESCRIPTION . . . . . . . . . . 5-1

5.1 GENERAL SYSTEM DESCRIPTION . . . . . . . . . . . . 5-1

5.2 THE 207-SL RETENTION BASINS ............ 5-1

$5.3222-$ SA STANDARDS LABORATORY ............. 5-3

5.4 THE 219-S WASTE HANDLING FACILITY .......... 5-3

$5.5222-S$ WASTEWATER DRAIN SYSTEM DESCRIPTION ........ 5-3

5.5.1 Basement Tunnels . . . . . . . . . . . . . 5-3

5.5.2 First Floor Analytical Section ......... 5-4

5.5.3 Second Floor Equipment Room . . . . . . . . . . . 5-4

5.6 FRENCH DRAINS . . . . . . . . 5-5

5.7 THE 219-S WASTE HANDLING FACILITY OUTLET VALVE (JUMPER) . . 5-5

6.0 EFFLUENT MONITORING/SAMPLING SYSTEM DESIGN CRITERIA . . . . . . . 6-1

6.1 CURRENT DESIGN CRITERIA . . . . . . . . . . . . 6- 6-1

6.2 SUGGESTED DESIGN CRITERIA . . . . . . . . . . . . 6-1

7.0 CHARACTERIZATION OF CURRENT EFFLUENT MONITORING SYSTEM . . . . . 7-1

8.0 HISTORICAL MONITORING AND SAMPLING DATA FOR EFFLUENT STREAMS . . . 8-1

8.1 NORMAL CONDITIONS .................... $8-1$

8.2 UPSET CONDITIONS . . . . . . . . . . . . . 8-1

9.0 SAMPLE ANALYSIS . . . . . . . . . . . . . . . 9-1

9.1 The 222-S LABORATORY EFFLUENT STREAM . . . . . . . . . . . 9-2

9.2 The 222 -SA LABORATORY EFFLUENT STREAM . . . . . . . . . . 9-2

9.3219 -S WASTE HANDLING FACILITY . . . . . . . . . . . . . 9-3

9.4 SUMMARY . . . . . . . . . . . . . . . . . . . . 9-3

9.4.1 U.S. Department of Energy Analytical and

Laboratory Guidelines . . . . . . . . . . . . 9-3

10.0 NOTIFICATION AND REPORTING REQUIREMENTS . . . . . . . . . . 10-1

10.1 REQUIREMENTS . . . . . . . . . . . . . . . . 10-1

10.1.1 Occurrence Identification and Immediate Response . . 10-1

10.2 OCCURRENCE CATEGORIZATION ............... . 10-1

10.2.1 Radioactive Release . . . . . . . . . . . . . 10-2

10.2.2 Hazardous Materials Release . . . . . . 10-3

10.2.3 Discovery of Radioactive or Hazardous Material

Contamination Due to U.S. Department

of Energy Operations ......... . . 10-3

10.2.4 Agreement and Compliance Activities . . . . . . . . 10-4

11.0 INTERFACE WITH THE OPERATIONAL ENVIRONMENTAL SURVEILLANCE

PROGRAM . . . . . . . . . . . . . . . . . . . 11-1

11.1 DESCRIPTION . . . . . . . . . . . . . . . . . 11-1

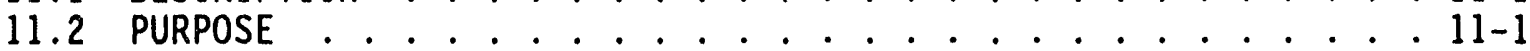

11.3 BASIS . . . . . . . . . . . . . . . . . .

11.4 MEDIA SAMPLED AND ANALYSES PERFORMED . . . . . . . . . 11-2

11.5 LOCATIONS . . . . . . . . . . . . . . . . . . . . . . 11-2

11.6 PROGRAM REVIEW.................... . . . . . . . . 
CONTENTS (continued)

11.7 SAMPLER DESIGN . . . . . . . . . . . . . . . 11-3

11.8 COMMUNICATION . . . . . . . . . . . . . . . . . 11-3

11.9 REPORTS .......................... . . . . . .

12.0 qUALITY ASSURANCE PROJECT PLAN . . . . . . . . . . 12-1

12.1 PURPOSE . . . . . . . . . . . . . . . . 12-1

12.2 OBJECTIVE ................... . . . . . . . .

12.3 REQUIREMENTS . . . . . . . . . . . . . 12-1

12.4 FACILITY-SPECIFIC REQUIREMENTS . . . . . . . . . . 12-2

13.0 INTERNAL AND EXTERNAL PLAN REVIEW . . . . . . . . . . . 13-1

14.0 COMPLIANCE ASSESSMENT . . . . . . . . . . . . . . . . . . 14-1

14.1 LIQUID EFFLUENTS GUIDANCE DERIVED FROM U.S. DEPARTMENT

OF ENERGY, FEDERAL, AND STATE REGULATIONS . . . . . . . 14-1

14.1.1 General . . . . . . . . . . . . . . . . 14-1

14.1.2 Nonradioact ive Liquids . . . . . . . . . . . . . . . . 14-1

14.1.3 Radioactive Liquids ............ . . 14-3

14.2 COMPARISON OF CURRENT AND PLANNED LIQUID EFFLUENT

MONITORING AGAINST REGULATORY COMPLIANCE . . . . . . . . . . 14-4

14.2.1 The 207-SL Retention Basins..... . . . . . . 14-4

14.2.2 The 222-SA Laboratory . . . . . . . . . . . . . 14-5

14.2.3 The 219-S Waste Handling Facility . . . . . . 14-5

15.0 SUMMARY AND CONCLUSIONS . . . . . . . . . . . . 15-1

16.0 ATTACHMENTS . . . . . . . . . . . . . . . . 16-1

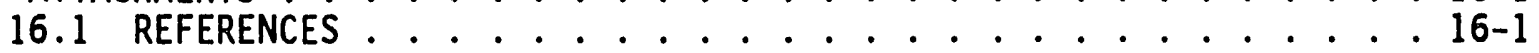




\section{WHC-EP-0480-1 \\ LIST OF FIGURES}

2-1 Location of the 222-S Laboratory Complex at the Hanford Site . . . 2-2

2-2 222-S Laboratory Complex . . . . . . . . . . . . . . . . 2-3

2-3 219-S Building Tanks 101, 102, and 103 ............ 2-5

2-4 222-S Laboratory Wastewater System . . . . . . . . . . . . . . 2-9

4-1 222-S Laboratory Coolant and Condensate Flow Diagram . . . . . . . 4-2

4-2 Airflow and Filtration Schematic for 222-S Laboratory . . . . . 4-6

5-1 222-S Laboratory Complex Wastewater System and French Drains . . . 5-2 
WHC-EP-0480-1

\section{LIST OF TABLES}

2-1 Influent Stream 219-S Waste Designation Summary . . . . . . . 2-10

3-1 Applicable Regulations and Standards . . . . . . . . . . . 3-2

4-1 Facility Effluent Monitoring Plan Determination Summary . . . . . 4-11

6-1 Sampling Criteria and Materials Suitable for Samplers

and Sample Containers ... . . . . . . . . . . . . 6-3

7-1 Current Sampling/Monitoring Procedures . . . . . . . . . . . 7-2

7-2 Liquid Effluent Discharge Specifications . . . . . . . . . . 7-3

8-1 Historical Concentration and Total Discharge of Radioactivity in 222-S Wastewater Effluent Concentration $(\mu \mathrm{C} \mathrm{i} / \mathrm{mL}$ ) and Total (Ci)

Radionuclides Released ................ . 8-2

8-2 Historical Nitrate $\left(\mathrm{NO}_{3}^{-}\right)$and Total Organic Carbon in 222-S Wastewater .................. 8-3

9-1 Summary of Sample Analysis Requirements For Liquid Effluents . . . 9-4

9-2 Laboratory Procedures . . . . . . . . . . . . . . . . 9-5

9-3 Data Analyses and Statistical Treatment . . . . . . . . . . . 9-6

12-1 Westinghouse Hanford Supporting Procedures for Facility Effluent Monitoring Plan Activities.............. . 12-3

12-2 Supporting Documents and Procedures for 222-S Laboratory Complex Facility Effluent Monitoring Plan Activities . . . . . . 12-4

12-3 Analytes of Interest and Reference Analytical Methods for Facility Effluent Monitoring Plan Activities at the 222-S Laboratory Complex 


\section{LIST OF TERMS}

$\begin{array}{ll}\text { ACV } & \text { administrative control value } \\ \text { ALARA } & \text { as low as reasonably achievable } \\ \text { BAT } & \text { best available technology } \\ \text { CAM } & \text { continuous air monitor } \\ \text { CERCLA } & \text { Comprehensive Environmental Response, Compensation, and } \\ \text { CFR } & \text { Liability Act of 1980 } \\ \text { DCG } & \text { Code of Federal Regulations } \\ \text { DOE } & \text { derived concentration guide } \\ \text { ECOTogy } & \text { U.S. Department of Energy } \\ \text { EDE } & \text { Washington State Department of Ecology } \\ \text { EPA } & \text { effective dose equivalent } \\ \text { FEMP } & \text { U.S. Environmental Protection Agency } \\ \text { FRP } & \text { Facility Effluent Monitoring Plan } \\ \text { FY } & \text { fiberglass-reinforced pipe } \\ \text { HEPA } & \text { fiscal year } \\ \text { HVAC } & \text { High Efficiency Particulate Air (filter) } \\ \text { ICRP } & \text { heating, ventilation, and air conditioning } \\ \text { LES } & \text { International Commission on Radiological Protection } \\ \text { ND } & \text { Liquid Effluent Study } \\ \text { NESHAP } & \text { none detected } \\ \text { NPDES } & \text { National Emission Standards for Hazardous Air Pollutants } \\ \text { NR } & \text { National Pollutant Discharge Elimination System } \\ \text { OSHA } & \text { none reported } \\ \text { PNL } & \text { Occupational Safety and Health Administration } \\ \text { POTW } & \text { Pacific Northwest Laboratory } \\ \text { QA } & \text { Publicly Owned Treatment Works } \\ \text { QAPP } & \text { quality assurance } \\ \text { QAPjP } & \text { Quality Assurance Program Plan } \\ \text { RCRA } & \text { Quality Assurance Project Plan } \\ \text { RL } & \text { Resource Conservation and Recovery Act of 1976 } \\ \text { RQ } & \text { U.S. Department of Energy, Richland Field Office } \\ \text { SARA } & \text { reportable quantity } \\ \text { TCLP } & \text { Superfund Amendment and Reauthorization Act of 1986 } \\ \text { TLD } & \text { toxic characteristic leach procedure } \\ \text { TOC } & \text { thermoluminescent dosimetry } \\ \text { TRU } & \text { total organic carbon } \\ \text { TSD } & \text { transuranic } \\ \text { VCP } & \text { treatment, storage, and disposal } \\ \text { VOC } & \text { vitrified clay pipe } \\ \text { WAC } & \text { Wolatile organic compound } \\ \text { Westinghouse } & \\ \text { Hanford } & \text { Westinghouse Hanford Company } \\ & \end{array}$


WHC-EP-0480-1

\begin{tabular}{|c|c|c|}
\hline \multicolumn{3}{|c|}{ METRIC CONVERSION CHART } \\
\hline \multicolumn{3}{|c|}{ INTO METRIC } \\
\hline If you know & Multiply by & To get \\
\hline \multicolumn{3}{|c|}{ Length } \\
\hline inches & 2.54 & centimeters \\
\hline feet & 0.3048 & meters \\
\hline \multicolumn{3}{|c|}{ Volume } \\
\hline gallons & 3.786 & liters \\
\hline cubic feet & 0.02832 & cubic meters \\
\hline \multicolumn{3}{|c|}{ Area } \\
\hline square feet & 0.09 & square meters \\
\hline \multicolumn{3}{|c|}{ Mass (Weight) } \\
\hline ounce & 28.0 & grams \\
\hline pound & .45 & Kilograms \\
\hline \multicolumn{3}{|c|}{ OUT OF METRIC } \\
\hline \multicolumn{3}{|c|}{ Length } \\
\hline centimeters & 0.3937 & inches \\
\hline meters & 3.28 & feet \\
\hline \multicolumn{3}{|c|}{$1^{\circ} \mathrm{F}=\left(\frac{9}{5}{ }^{\circ} \mathrm{C}\right)+32$} \\
\hline \multicolumn{3}{|c|}{$\begin{array}{c}1 \mathrm{Btu} / \mathrm{h}=2.930711 \mathrm{E}=01 \text { watts } \\
\text { (International Table) }\end{array}$} \\
\hline
\end{tabular}


WHC-EP-0480-1

This page intentionally left blank. 
WHC-EP-0480-1

\section{FACILITY EFFLUENT MONITORING PLAN FOR THE 222-S LABORATORY}

\subsection{INTRODUCTION}

This document presents the Facility Effluent Monitoring Plan (FEMP) for the 222-S Laboratory Complex.

It is the policy of the U.S. Department of Energy (DOE) and Westinghouse Hanford Company (Westinghouse Hanford) to conduct effluent monitoring to determine whether the public and the environment are adequately protected during DOE operations, and whether operations are in compliance with DOE and other applicable Federal, State, and local radiation standards and requirements. It is also DOE and Westinghouse Hanford policy that effluent monitoring programs meet high standards of quality and credibility.

The purpose of this document is to fulfill the DOE requirement for a FEMP for each facility that contains hazardous materials that could impact both public and employee safety and the environment (DOE 1988a).

The scope of this document includes a program plan for monitoring and characterizing radioactive and nonradioactive hazardous materials discharged in the 222-S Laboratory Complex effluents. This plan includes gaseous and liquid effluent monitoring systems for radioactive and nonradioactive hazardous pollutants that could be discharged uncer routine and/or upset conditions. The plan describes the airborne and liquid effluent paths, the associated sampling and monitoring systems of the 222-S Laboratory Complex, and provides sufficient information on the effluent characteristics and the effluent monitoring systems so that a compliance assessment against requirements may be performed. Adequate details are supplied such that radioactive and hazardous material source terms may be related to specific effluent streams which are, in turn, related to discharge points and then compared to the effluent monitoring system capability.

Information has been included from the 222-S Laboratory Complex FEMP Determination in the Facility Effluent Monitoring Plan Determinations for the 200 Area Facilities, WHC-EP-0440 (WHC 1991d). Determinations of whether the complex met the criteria for requiring FEMPs were performed for this report. The determinations were in accordance with $A$ Guide for Preparing Hanford Site Facility Effluent Monitoring Plans, WHC-EP-0438 (WHC 1991a). The evaluations were based upon information obtained in documents, and from interviews with cognizant engineers.

A FEMP is required if the total projected dose from radionuclides exceeds $0.1 \mathrm{mrem} / \mathrm{yr}$ effective dose equivalent (EDE) from any one discharge point or if any one regulated material discharged from a facility to the environment exceeds $100 \%$ of a reportable quantity (RQ) as listed in 40 Code of Federal Regulations (CFR) 302.4 (EPA 1985a) or is designated a Dangerous Waste in Washington Administrative Code (WAC) 173-303-70 through WAC 173-303-103 (Ecology 1991a). 
Data used in this evaluation to convert projected radionuclide releases to offsite doses were developed by Pacific Northwest Laboratory (PNL) (Nickels 1991). Airborne releases were assumed to occur from either a $10-\mathrm{m}$ stack or at ground level from a central location in the 200 West Area. The distance from the 200 West Area release point to the offsite location was assumed to be $24,000 \mathrm{~m}$.

Where possible, actual monitoring data were used to project the radiation dose to offsite individuals. When actual data were used, a protection factor of 3000 was assumed for effluent systems that were normally filtered with High Efficiency Particulate Air (HEPA) filters. This was to satisfy the U.S. Environmental Protection Agency (EPA) requirement that no engineered controls be considered in the FEMP determination. Where no actual monitoring data existed, the best available source term data were used. The DOE Orders also require a FEMP evaluation to be performed under anticipated facility upset conditions.

Also where possible, individual radionuclides were used to calculate radiation doses. In some cases, only gross alpha and gross beta figures were available. In those cases, ${ }^{239} \mathrm{Pu}$ and ${ }^{90} \mathrm{Sr}$ were used to represent total alpha and beta, respectively.

Three liquid effluents were identified as requiring a FEMP, based on their potential for releasing hazardous waste constituents under upset conditions. The facilities from which these effluents originate are the 207-SL Retention Basins, the 222-SA Laboratory, and the 219-S Waste Handling Facility. In-depth details of these effluents and their associated monitoring systems are included in this FEMP. Information on other routine and potential airborne and liquid effluents also is included in this FEMP for completeness, but is not discussed to the same level of detail as the information on the three liquid effluents. 
WHC-EP-0480-1

\subsection{FACILITY DESCRIPTION}

\subsection{PHYSICAL PLANT}

The 222-S Laboratory Complex is located in the southeast corner of the 200 West Area (Figure 2-1). The facilities considered in this report are composed of the main laboratory complex (222-S) and a number of ancillary buildings and structures (Figure 2-2).

The 222-S Laboratory is a two-story, aboveground building $322 \mathrm{ft}$ long and $107 \mathrm{ft}$ wide, with a subterranean service level. This building is divided into laboratory support spaces, office spaces, a multicurie wing, and supplemental service areas. The building is designed with its own waste-storage facility, decontamination facility, fire protection and alarm system, ventilation system, and radiation monitoring systems.

The first floor of 222-S is divided into three general areas. The west end contains the lunchroom, offices, and changerooms, which are maintained free of radioactivity and toxic chemicals. The central section contains laboratories and service areas for work with $10 \mathrm{w}-1$ evel (generally $<10 \mathrm{mr} / \mathrm{h}$ ) radioactive and/or toxic materials, although an occasional intermediate level sample may be located in this area. The east end, commonly referred to as the Multicurie Section, contains laboratories, hot-cells, and service areas for working with intermediate-level (generally $>10 \mathrm{mr} / \mathrm{h}$ ) radioactive and/or toxic materials. The central and east sections contain laboratory benches and hoods that are supplied with services such as electrical outlets, sanitary and distilled water, compressed air, and process vacuum. The partial basement contains service piping, vacuum pumps, a scanning electron microscope laboratory', and a fully equipped counting room. The second floor contains the ventilation supply fans, supply and exhaust ductwork, the ventilation system operation and control room, a glass shop, a nitric acid supply tank, and storage areas. This area is maintained free of radioactive contamination.

The 222-SA Laboratory is a modular building located southeast of the 222-S Laboratory. Part of this laboratory prepares nonradioactive standards for the 200 Area laboratories. The other section of the laboratory is used for cold (nonradioactive) process development work and standards preparation.

The 2716-S Storage Building, located south of the 222-S Laboratory, is a $1,700 \mathrm{ft}^{2}$ metal building with $200 \mathrm{ft}^{2}$ partitioned off for the storage of acids and bases. It provides both long- and short-term storage capability for laboratory materials and contains no radioactive materials. It is protected with a dry-pipe automatic sprinkler system, heat detectors, a manual pullbox, and portable fire extinguisher. The $200 \mathrm{ft}^{2}$ hazardous storage area is equipped with explosion-proof lighting, a separate ventilation system, and a fire wall to meet 0ccupational Safety and Health Administration (OSHA) safety requirements for volatile liquid combustibles, al though no volatile 1 iquid combustibles are stored in the facility. The building serves routinely as a satellite accumulation area for waste batteries and spent copier toner 
Figure 2-1. Location of the 222-S Laboratory Complex at the Hanford Site.

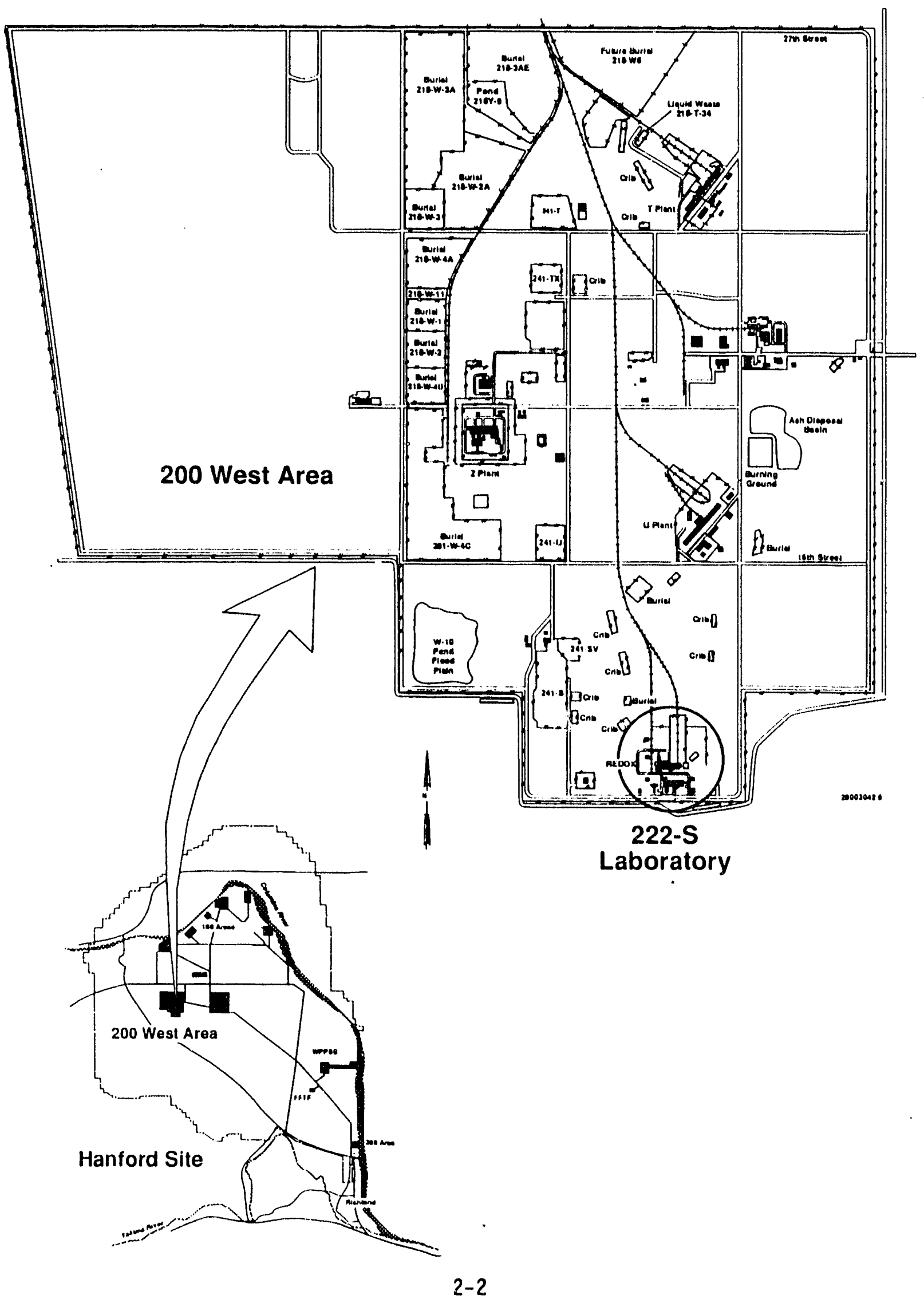


WHC-EP-0480-1

Figure 2-2. 222-S Laboratory Complex.
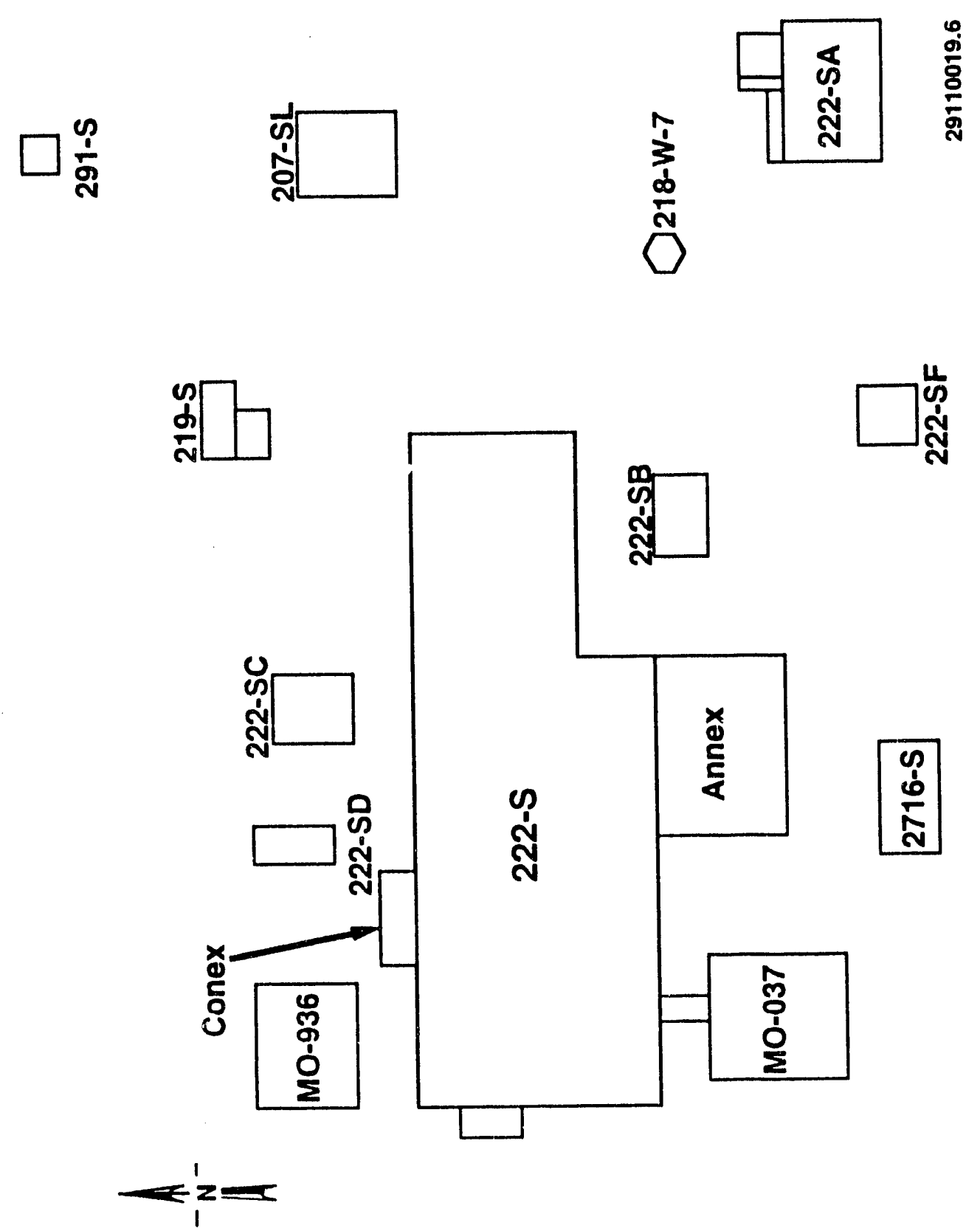
cartridges. The building also is used occasionally as a temporary satellite accumulation area for nonlaboratory-related waste such as pesticides or hexachlorophene containing soap. There are no floor drains in this building.

The 222-S Laboratory Annex houses the maintenance shop and the counting room filter building.

Wastewater from the laboratory, normally free of radioactive and hazardous chemical contamination, is routed to the 207-SL Retention Basins. The 207-SL Retention Basins acts as a temporary holding facility for potentially radioactive or hazardous liquid effluents before analys is to determine suitability for discharge to the $216-5-26$ Crib. This facility is a covered, belowgrade concrete structure, directly east of the 222-S Building. Two 25,000-gal compartments allow batch collection, sampling, and discharge of the waste. Wastewater is not released to the $216-5-26$ crib until it is analyticalily determined to comply with release criteria (WHC 1991b). The $216-5-26$ crib is located Southeast of the 222-S Laboratory, outside the 200 West Area exclusion area. Water that fails the pH criteria for release to the 216-S-26 Crib will be neutralized and resampled. Water not meeting radioactive and/or hazardous waste specifications may be transferred to the 219-S Waste Handling Facility for retention before transfer via tanker truck or underground transfer lines to Tank Farms or other appropriate facilities.

The 219-S Waste Handling Facility (Figure 2-3) is a permitted treatment, storage, and disposal (TSD) facility. The 219-S is used for the collection of radioactive and radioactive hazardous (mixed) liquid waste generated by the 222-S Laboratory. This facility consists of a $27-\mathrm{ft}$ by $25-\mathrm{ft}$ belowgrade containment vault, a $22-\mathrm{ft}$ by $13-\mathrm{ft}$ transite building, and an attached 13-ft by $8-\mathrm{ft}$ concrete-walled sample gallery. The containment vault is divided into two sections called cells $A$ and $B$, which contain the three liquid waste tanks (TK-101, TK-102, and TK-103) and a moisture de-entrainer tank (TK-105). The waste tanks are vented through the de-entrainer and a HEPA filter to the atmosphere via the 296-S-16 Stack. The transite section contains the operating gallery and the pipe trench plus a 700-gal tank (TK-201) of caustic, which is used to neutralize the waste tanks. The concrete sample gallery contains the waste sampling hood, which is vented through two stages of HEPA filtration to the atmosphere via the 296-S-23 Stack.

The 222-SD Solid Waste Handling and Storage System is a concreteshielded, drum-storage area that was constructed to stage drums containing radioactive materials. This area is used for temporary storage of radioactive waste drums before they are transferred to the burial ground. It is equipped with an electrically driven jib crane for remotely positioning the drums in the storage area and for remotely loading the drums on the bed of the waste truck.

The 222-SC Filter Building contains the filtration for hot-cells 1-A, $1-E-1,1-E-2$, and $1-F$. The 222-SC Filter Building houses five parallel pairs of HEPA filters, which provide second- and third-stage HEPA filtration to hotcell exhaust air before it enters the main exhaust plenum and final HEPA filtering in the 222-SB Filter Building. In total, four stages of HEPA filtration are provided for hot-cell exhaust. 
Figure 2-3. 219-S Building Tanks 101, 102, and 103.

(Note: Tank 101 is identical to tank 102.)

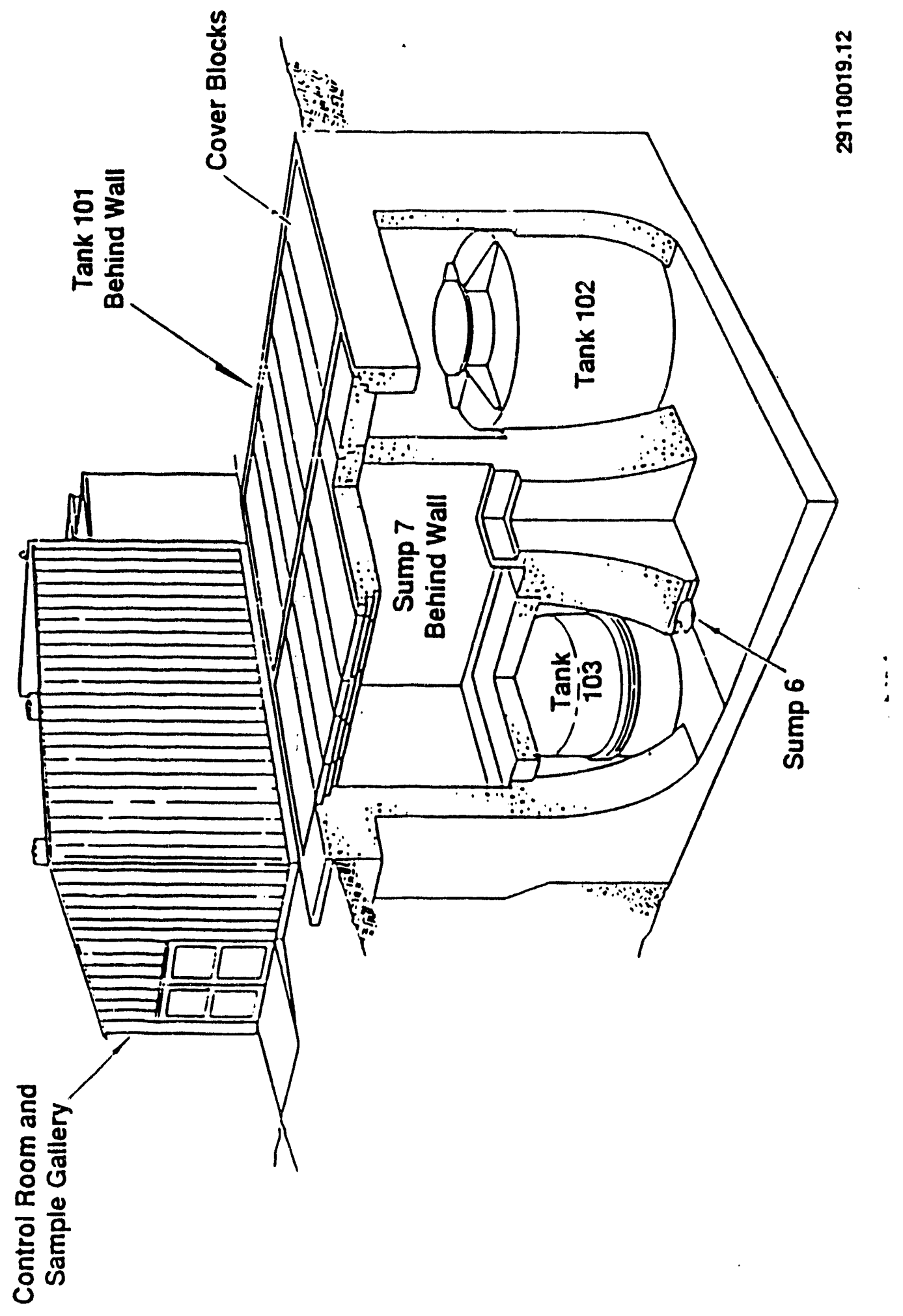


The 222-SB Filter Building houses 96 single-stage HEPA filters to provide final filtration for the 222-S Laboratory. Under normal operation of the ventilation system, two electrically powered, $46,000 \mathrm{ft}^{3} / \mathrm{min}$ fans exhaust air from the laboratory. Exhaust air leaves the 222-S Building through the 296-S-21 Stack. A third exhaust fan, driven by a diesel engine, will provide half of the normal operation of the exhaust system if power is iost to the two electrically-powered exhaust fans. All HEPA filters in laboratory hoods, glove boxes, hot-cells, auxiliary laboratory outlets, and stack discharges are tested annually with di(2-ethylhexyl) sebacate or equivalent to assess filter efficiency. Filters that fail to meet performance standards are replaced.

The 218-W-7 Dry Waste Burial Vault is located $40 \mathrm{ft}$ southeast of 222-S Laboratory. The concrete burial vault and associated dome and vent structure is approximately $25 \mathrm{ft}$ by $12 \mathrm{ft}$. This underground concrete vault was removed from service around 1960. It was used primarily for disposal of plutonium-contaminated dry hood waste generated by the 222-S Laboratory. Access to the tank is via a locked hatchway.

The 216-S-26 Crib receives all wastewater that is collected in the 207-SL Retention Basins and that meets radiological and chemical limits. In addition, this crib also receives 222-SA Laboratory wastewater and steam condensate from the 291-S Stack Fan House that bypasses the 207-SL Retention Basins. The crib was designed to handle Laboratory wastewater at $75,000 \mathrm{gal} /$ day or $25,000 \mathrm{gal} / 8-\mathrm{hr}$ shift. Currently, the crib receives approximately $7,000 \mathrm{gal} / \mathrm{day}$ in the summer and about 15,000 gal/day during the winter months. Operation and control of this crib is the responsibility of Tank Farm Operations.

\subsection{PROCESS DESCRIPTION}

\subsubsection{Past Practices}

The 222-S Laboratory facilities were constructed in 1950-1951 to provide analytical and plant support for the Hanford Reduction Oxidation Plant. Through the years, the missions of the 222-S Laboratory have changed and modifications have been made in response to new requirements and to increasingly restrictive operating and design criteria.

\subsubsection{Current Practices}

The current operation of the 222-S facilities includes the provision of analytical and radiological chemistry services in support of Hanford Site processing plants. The emphasis is on waste management, chemical processing, environmental monitoring effluent programs at B Plant, the Uranium Oxide Plant, Tank Farms, the 242-A Evaporator, the Waste Encapsulation and Storage Facility, the Plutonium-Uranium Extraction Facility, the Plutonium Finishing Plant, process development/impact activities, and essential materials. The laboratory also supplies analytical services in support of ongoing waste tank characterization. 
WHC-EP-0480-1

\subsection{POTENTIAL SOURCE TERMS}

For a number of the major waste streams, effluent monitoring data provided reasonable estimates of constituents expected under routine operating conditions. The potential inventory at risk was also evaluated under upset conditions. Upset conditions are defined as the failure of one administrative or physical barrier.

The potential radionuclide mix for the 222-S Facility, as discussed in WHC-EP-0141-2 (Brown et al. 1990) and WHC-EP-0342 (WHC 1990a), is assumed to be predominantly plutonium, americium, cesium, and strontium. The chemical inventory is much more complex and a number of assumptions were used to make a preliminary assessment of which chemicals required further consideration. A major criterion for further consideration was that 222-S (or other facilities) had one or more chemicals in its inventory in an amount greater than the RQ, as defined in 40 CFR 302, Table 302.4 (EPA 1985a). Also considered was a scenario where the release of a chemical would contaminate the 207-SL Retention Basins such that subsequent liquid discharge to the 216-S-26 Crib would be in violation of WAC 173-303 (Ecology 1991a) and/or 40 CFR 302 . The individual chemicals determined by this method are discussed in Section 4.0 .

\subsubsection{The 222-SA Laboratory}

The 222-SA Laboratory wastewater consists of yacuum pump cooling water, water purification system backflush water, water from sink and hood drains, and the glass washer. Presently, this stream discharges directly to the 216-S-26 Crib. The stream will be rerouted to the 207-SL basins [estimated fiscal year (FY) 1994] to allow sampling before discharge. Radionuclides are excluded from the 222-SA Facility, and multiple physical and administrative barriers would have to be violated before radionuclide contamination could be released into or from the facility.

Hazardous materials will not be disposed of to the drains under normal operating conditions. However, many of the materials listed on the 222-SA Superfund Amendment and Reauthorization Act of 1986 (SARA) Chemical Inventory could be accidentally discharged to the laboratory waste stream under upset conditions. Thus, the entire list of chemicals was evaluated against the criteria discussed in Section 2.3.

\subsubsection{The 222-S Laboratory}

The 222-S Laboratory is limited to $177 \mathrm{~g}$ of fissile material in the facility at any one time. The maximum inventory of the principal radionuclides anticipated was estimated as $10 \mathrm{Ci}$ of ${ }^{239} \mathrm{Pu}, 298 \mathrm{Ci}$ of ${ }^{90} \mathrm{Sr}$, and $47 \mathrm{Ci}$ of ${ }^{137} \mathrm{CS}$ (WHC 1989a). Americium-241 has been identified as another potentially major inventory nuclide. For purposes of this document, the projected radionuclide inventory in the laboratory was not used directly to predict releases. Instead, the various airborne pathways (stacks) were evaluated based upon effluent release data as published in WHC-EP-0141-2 (Brown et al. 1990) and appropriate assumptions regarding loss of engineered controls. A discussion of the specific data and assumptions used is found in Section 4.0. 
WHC-EP-0480-1

Liquid pathway releases were evaluated using radionuclide composition as indicated by liquid effluent monitoring results of the 222-S waste in the 207-SL Retention Basins and the 219-S tanks. These inventories are discussed in Sections 2.3.3 and 2.3.4. A discussion of the potential releases under normal and upset cenditions is found in Section 4.0.

The hazardous chemicals potentially emitted via the air pathway during normal operations are those that are (1) routinely used in the various laboratory procedures and volatilized during the process or (2) volatilized during upset conditions. The chemicals used routinely that may be volatilized during routine operations are ethanol, toluene, and xylene. The total inventory, based on the 222-S SARA Chemical Inventory, was less than an RQ and thus, they are not considered further.

Under upset conditions, an additional inventory at risk was the volatile chemicals of the 222-S SARA Chemical Inventory that were present above RQ. These chemicals are considered further under the specific upset conditions and discussed in Section 4.0.

The liquid effluents from the 222-S Facility are transferred to 207-SL Retention Basins via a fiberglass reinforced pipe enclosed in a vitrified clay pipe, which in turn is enclosed in a concrete pifo. Liquid effluents are transferred to the 219-S Facility via stainless steel pipes encased in concrete pipe trenches from the point of exit from 222-S to the point of entry into the 219-S vault. The potential for liquid effluents from 222-S reaching the environment while being transferred to 207-SL or the 219-5 Facility is considered to be low (without the loss of two or more barriers). The FEMPs are to consider routine effluents and effluents that would reach the environment with loss of one engineered or administrative barrier; thus, the 222-S liquid effluents are not further considered here. See Sections 2.3.3 and 2.3.4 for a discussion of inventory at risk.

\subsubsection{The 207-SL Retention Basins}

The 207-SL Retention Basins collect liquid effluents exiting 222-S and 219-S (Figure 2-4) before sampling, analysis, and subsequent discharge to the crib. The 222-S wastewater 1:.e handles steam condensate; sampling, analysis, and subsequent water from laboratory sink drains; drain overflow from the supply fan air washers; and discharge from sumps. Vacuum pump cooling water is now recirculated and is no longer disposed of to 207-SL. With regard to radioactive inventory, the major nuclides that are anticipated are ${ }^{90} \mathrm{Sr},{ }^{239} \mathrm{Pu}$, ${ }^{24} \mathrm{Am}$, and ${ }^{137} \mathrm{Cs}$ (Table C-19, Brown et al. 1990). The normal procedure of performing gross alpha and gross beta measurements before discharge to the 216-S-26 Crib provides an upper limit to potential routine emissions to the soil column and will be further discussed in Section 4.0 .

Disposal of chemicals to the drains is strictly prohibited without consent of the 222-S Laboratory Engineering and/or the Hazardous Material Unit Group Manager. 
Figure 2-4. 222-S Laboratory Wastewater System.

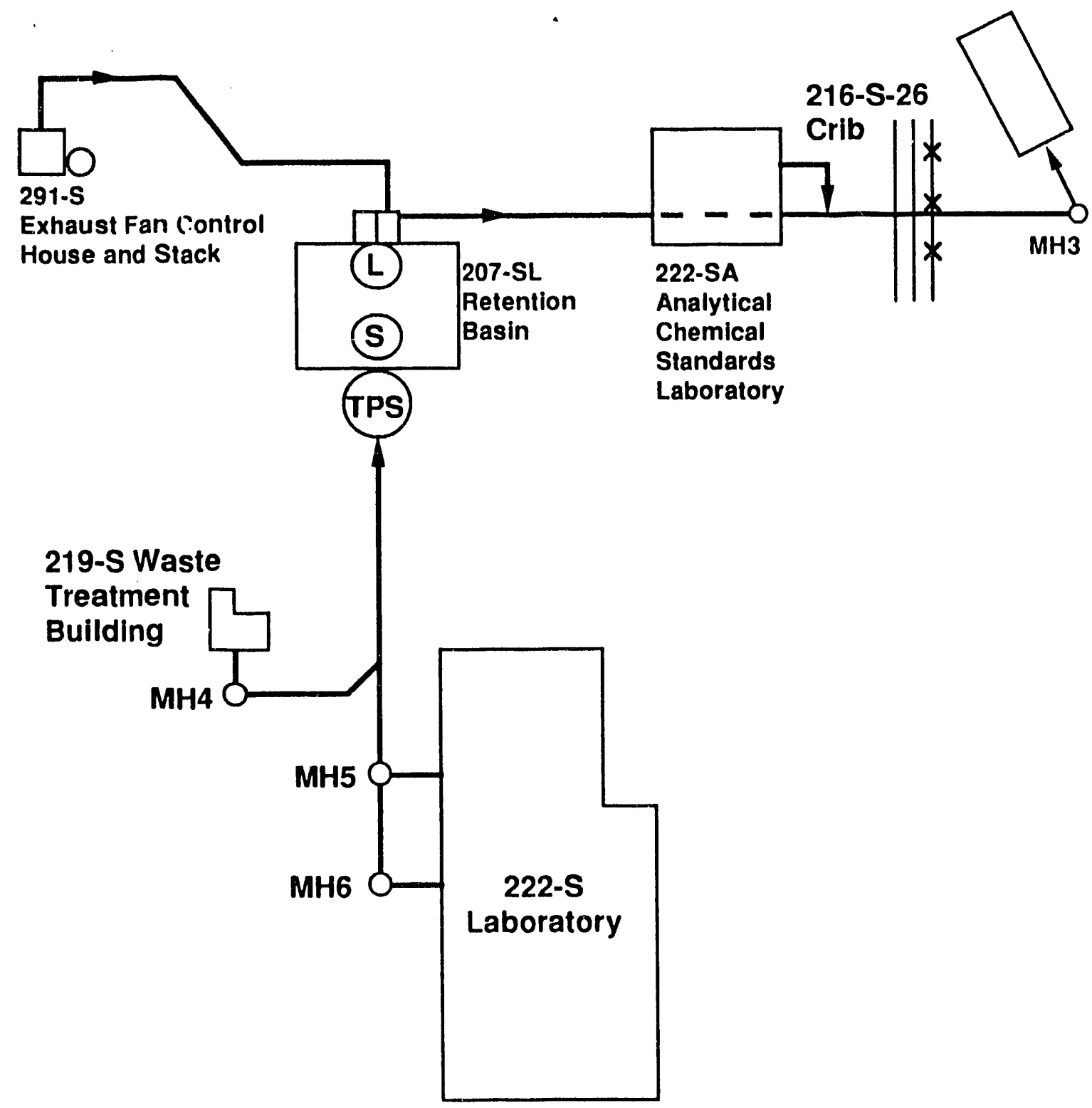

(L) = Flow measurement location

MH = Manhole

(5) = Sampling location for samples (grab samples)

TPS = Time proportional sampler (Record) 
Many of the materials listed on the 222-S SARA Hazardous Chemical Inventory can be accidentally discharged to the 207-SL Retention Basins. However, if a chemical is spilled or accidentally poured into a wastewater drain, it will be contained in the retention basin and handled appropriately. Prohibiting disposal of chemicals to the drains and having a temporary holding system are excellent measures; however, the present analytical parameters (pH, nitrate, TOC, gross alpha, gross beta) are not sufficient to ensure that any hazardous waste is discharged to the ground via the 216-S-26 Crib. Thus, the entire inventory of chemicals was considered and is further discussed in Section 4.0 .

\subsubsection{The 219-S Waste Handling Facility}

The 219-S Waste Handling Facility is a permitted TSD facility, used for the collection of radioactive and mixed liquid waste generated by the 222-S Laboratory.

Waste tanks TK-101, TK-102, and TK-103 contain the radioactive hazardous wastes from the 222-S Laboratory. Tank TK-101 and TK-103 receive waste, neutralization occurs in TK-101 or TK-103, and the neutralized waste is transferred to TK-102 for subsequent shipment to Tank Farms.

The maximum plutonium allowed in the tanks is $150 \mathrm{~g}$ (Harris and McNamar 1987). If that inventory was distributed in the total working volume of the tanks $(8,460 \mathrm{gal})$, the concentration would be $2 \times 10^{-3} \mathrm{~g} / \mathrm{L}$. The same document referenced above gave a typical plutonium concentration of $4 \times 10^{-4} \mathrm{~g} / \mathrm{L}$. The specification-1 imit per batch transferred to Tank Farms is $<1.3 \times 10^{-2} \mathrm{~g} / \mathrm{L}$ (Fuller 1988a).

A hazardous waste assessment of the 219-5 influent stream was performed (Warwick 1992) and the stream was designated as a toxic, listed, characteristic dangerous waste according to WAC 173-303-070 (Ecology 1991a). The designations are summarized in Table 2-1 and indicate the presence of a large inventory of mixed waste.

Table 2-1. Influent Stream 219-S Waste Designation Summary.

\begin{tabular}{|l|l|}
\hline $\begin{array}{c}\text { WAC } 173-303 \text { Waste } \\
\text { Designation }\end{array}$ & \multicolumn{1}{|c|}{ Waste Characteristics } \\
\hline F001, F002 & Halogenated spent solvents \\
\hline F003, F005 & Non-halogenated spent solvents \\
\hline D002 & Corrosive/caustic \\
\hline D004 & Toxicity - arsenic \\
\hline$D 005$ & Toxicity - barium \\
\hline$D 006$ & Toxicity - cadmium \\
\hline$D 007$ & Toxicity - chromium \\
\hline$D 008$ & Toxicity - lead \\
\hline
\end{tabular}


Table 2-i. Inf?uent Stream 219-S Waste Designation Summary. (continued)

\begin{tabular}{|l|l|}
\hline D009 & Toxicity - mercury \\
\hline D010 & Toxicity - seleñium \\
\hline D011 & Toxicity - silver \\
\hline WT01 & Toxic waste mixture \\
\hline
\end{tabular}

Under upset conditions, the chemicals in the 222-S SARA Chemical Inventory are also potentiaily available to the 219-S waste tanks. These chemicals were evaluated and those that could be present in the tank in quantities greater than EPA's RQ release limits in 40 CFR 302 (EPA 1985a) or that could contaminate the waste to a level causing its WAC 173-303 (Ecology 1991a) or 40 CFR 302 waste designation to change, are evaluated further in Section 4.0 .

The 219-S facility aiso contains a 700-gal tank of approximately $50 \% \mathrm{NaOH}$ (TK-201). The contents of this tank, if released during an upset condition, would be a hacardou: waste under the corrosive waste designation ( $\mathrm{pH}>12.5)$; this is considered further in iection 4.0 .

\subsubsection{Nitric Acid Tanks}

An 800-gal nitric acid storage tank is located on the north side of the 222-5 Laboratory. The contents of this tank, if released during an upset condition, would be a hazardous waste under the corrocive waste designation $(\mathrm{pH}<2.0)$.

A secondary containment structure around the tank has a volume of $825 \mathrm{gal}$. An administrative limit exists that limits the number of gallons in the tank to 600 . Thus, during an upset condition (i.e., failure of a pipe, valve, or tank), there is no credible scenario for the release of concentrated nitric acid. Based on a lack of pntential release discussed above, a FEMP is not required.

A 150-gal nitric acid supply tank is located on whe second floor. In the event of a spill, the material would go into a containment area, which drains back to the $800-g a l$ nitric acid storage tank outside of the building. Since there is no reasonable pathway to the environment without a secnnd subsequent failure of engineered or admini strative barrier, this potential source term is not considered further.

\subsubsection{Nonhazardous Solid Low-Level Waste}

This waste stream consists of laboratory office trash and dry waste from laboratory areas. These wastes are generated only in 222-S Laboratory and not in 222-SA. Laboratory dry waste typically consists of surgical gloves, empty polyethylene bottles, and paper towels. These wastes are generally 
accumulated in drums and in individual laboratory areas. Full drums are staged on the 222-SD storage pad for shipment to the 200 West Area Burial Grounds. Low-level radioactive solid wastes $(>100 \mathrm{mR} / \mathrm{h})$ are accumulated in 55-gal drums. When full, these drums, as well as drums of broken glassware, are staged at a shielded storage pad (222-SD) north of the 222-S Building before shipment to the 200 West Area Burial Grounds. Large articles of solid waste from radiological control zones, which are certified free of surface contamination but which cannot be certified for unconditional release, are accumulated in wooden burial boxes outside the 222-S Building before disposal at the 200 West Area Burial Grounds.

No releases to the environment are anticipated during routine operations and no upset conditions have been identified that would cause a release.

\subsubsection{Mixed Solid Waste - Lead Waste}

Mixed solid waste consists of radioactive solid waste that is also dangerous waste. A primary source of mixed solid waste generated at 222-S is radioactively contaminated lead. Lead-mixed wastes are segregated from other solid radioactive wastes and are staged at the dangerous and mixed waste storage area (i.e., metal storage boxes) north of 222-S before shipment to the Central Waste Complex.

Lead-mixed wastes at 222-S are mainly broken lead sample carriers. There does not appear to be a method by which significant release to the environment can occur for this waste stream; however, this waste stream is regulated because the carriers appear to be solid waste (i.e., they are not being recycled) and lead is regulated as a dangerous waste. There does not appear to be any credible release scenario under routine or upset conditions. This source will not be considered further in this document.

\subsubsection{Cold Wastes}

Cold wastes consist of those wastes that are only hazardous wastes and are not radioactively contaminated. These wastes include outdated laboratory chemicals and laboratory chemical wastes, and are generated at both 222-S and 222-SA. These wastes are accumulated at satellite accumulation areas before packaging in iabpack drums for shipment to the 616 Building for ultimate offsite disposal. Waste batteries and copier toner cartridges are accumulated in satellite accumulation areas located in 2716-S.

These waste streams are regulated because they include chemicals that are dangerous wastes. These wastes include those that can be designated as dangerous because they are discarded chemical products (WAC 173-303-081), toxic mixtures (WAC 173-303-084), or characteristic wastes (WAC 173-303-090) (Ecology 1991a). There is no credible release scenario under routine or upset conditions for an environmental release. This source will not be considered further in this document. 


\subsubsection{Mixed Liquid Waste - Organic}

Organic mixed liquid wastes are generated at 222-S during the radiochemical separation processes conducted in the different laboratory hoods. No mixed wastes are generated at 222-SA. At 222-S, organic liquidmixed wastes are accumulated in polyethylene-coated glass bottles inside the laboratory hoods where the separation processes occur. When these bottles are full, they are transferred to the temporary (1ess-than-90-day) accumulation area and packaged in labpack drums. These drums are staged at the dangerous and mixed waste storage area (i.e., metal storage box) north of the 222-S Building before shipment to the Central Waste Complex.

Some liquid-organic-mixed waste (containing carbon tetrachloride) is generated in one of the 222-S Laboratories, and is reclaimed by distillation. This reclaimed solvent can be reused several times before it is necessary to dispose of it.

This waste stream is regulated because the organic waste is a dangerous waste. The organic solvents used at 222-S include those that are 1 isted as dangerous wastes under WAC 173-303-082; these wastes also may be designated as dangerous mixtures under WAC 173-303-084 (Ecology 1991a). There is no routine environmental release for this waste stream and there does not appear to be a credible scenario for a release under upset conditions.

\subsubsection{Mixed Liquid Waste - Aqueous}

Aqueous-mixed liquid wastes include aqueous phase wastes from radiochemical separation processes, discarded samples, and liquid decontamination wastes. Aqueous phase separation wastes are accumulated in bottles in laboratory hoods where the separation process occurs. When full, these bottles are transferred to a hood in room 2-B Slurp Hood for transfer to waste accumulation tanks located in the 219-S Waste Handling Facility.

Discarded samples also are sent to these tanks. Samples may be aspirated into tank 103 from hood 16 located in room 2-B, or they may reach the tanks through drains in hot-cells. Decontamination takes place in hood 16 (room 2-B) and decontamination wastes are drained into tank 101 . This waste stream is regulated because the aqueous wastes contain dangerous wastes. These wastes include corrosive dangerous wastes (WAC 173-303-090) and toxic waste mixtures (WAC 173-303-084) (Ecology 1991a). There may be a potential path to the environment during upset conditions. See Section 4.1.4 for a discussion of estimated releases.

\subsubsection{Mixed Solid Waste - Laboratory Chemicals}

Laboratory chemical wastes are accumulated with mixed liquid wastes in satellite accumulation areas before packaging for disposal. The outdated chemicals are recertified and put back into use or checked for radioactivity. If radioactive (i.e., $60 \mathrm{pCi} / \mathrm{gram}$ gross Alpha, $200 \mathrm{pCi} / \mathrm{gram}$ total activity), they are labpacked and sent to the Central Waste Complex; if they are not radioactive, they are packaged and sent to the 616 Building for storage before offsite disposal. 
This waste stream is regulated because the laboratory chemicals used at 222-S include chemicals that are dangerous wastes. These wastes include those that can be designated as dangerous because they are discarded chemical products (WAC 173-303-081), toxic mixtures (WAC 173-303-084), or characteristic wastes (WAC 173-303-090) (Ecology 1991a). There is no credible release scenario under routine or upset conditions. This source will not be considered further in this document.

\subsubsection{Waste Aerosol Cans}

Aerosol cans from within 222-S radiological control zones are individually surveyed and evaluated to determine if they have been properly emptied. The definition of an empty container in WAC 173-303-160 states that the container is considered empty (nonregulated) if the "pressure inside the container equals or nearly equals atmospheric pressure" (Ecology 1991a). Aerosol cans will only be considered hazardous waste if they are not properly emptied and still contain a hazardous waste. They will be handled as mixed waste if they are radioactively contaminated as well. Cans that are radiologically contaminated but properly emptied are disposed of as low-level solid waste. An accurate inventory of aerosol can products in use at $222-5$ has not been compiled and final procedures, which call for aerosol cans to be properly emptied before being disposed, do not presently exist.

The potential exists for cans that contain dangerous wastes to be disposed without being properly emptied. Generally, the aerosol cans contain less than a pound of material when full; thus, the potential amount of material left in an average-sized can is so small (less than one pound) that it is highly unlikely that any RQs would be disposed of. This waste stream is not considered further in this document.

\subsubsection{Transuranic Solid Waste}

Transuranic (TRU) wastes are not routinely generated at $222-S$. At the time of an earlier assessment (ICF 1989), some hoods were being removed from room $2-B$. These hoods had been assayed and estimated to possibly contain sufficient amounts of plutonium for designation as TRU wastes. The hoods were wrapped in plastic and stored in room 2-B awaiting processing for disposal. Currently, the hoods are in wooden boxes east of the 222-S Facility. There appears to be no plausible mechanism for release under routine or upset conditions. This waste stream is not considered further in this document.

\subsubsection{Waste Asbestos}

This waste stream is intermittent and consists of asbestos-removal activities in the 222-S Building. At the time of this assessment, no asbestos was awaiting shipment. Removal activities are performed in radioactively contaminated areas; thus, the waste asbestos is considered to be low-level radioactive waste. The wastes do not contain any dangerous waste constituents. It is double-bagged in polyethylene and placed in drums. Asbestos wastes are regulated under the Clean Air Act of 1977; however, there 
is no credible scenario under routine or upset conditions for a release to the environment. Thus, this waste stream is not considered further in this document.

\subsubsection{The 296-S-21 Stack Fan Emergency Diesel Tank}

The 296-S-21 stack fan emergency diesel tank is an underground tank used to store diesel that would power an emergency fan for the stack. The tank, which was installed in 1977, is constructed of carbon steel and has a capacity of $285 \mathrm{gal}$.

The tank is regulated under the Resource Conservation and Recovery Act of 1976 (RCRA) Subtitle I, 40 CFR 280 (EPA 1991a), 40 CFR 281 (EPA 1991b), Revised Code of Washington (RCW) 90 (RCW 1945), and WAC 173-360 (Ecology 1990C). The tank is required to be monitored by December 1994 for leaks. After 1998, it must be monitored every 30 days and have corrosion, spi11, and overflow protection.

Since the tank is regulated under the regulations cited above and has not exceeded the period set for compliance, it is not considered further in this document.

\subsubsection{The 218-W-7 Dry Waste Vault}

The 218-W-7 Dry Waste Vault (Operable Unit 200-R0-3) was used in the past to receive dry, packaged laboratory and sampler waste from the 222-S Laboratory. The estimated inventory as of $12 / 31 / 88$ for this vault consists of $37 \mathrm{Ci}$ of ${ }^{90} \mathrm{Sr}, 41 \mathrm{Ci}$ of ${ }^{137} \mathrm{Cs}, 8.7 \times 10^{-4} \mathrm{Ci}$ of uranium-isotopes, $7.9 \times 10^{-2} \mathrm{Ci}$ of plutonium-isotopes, and $1.5 \times 10^{-2} \mathrm{Ci}$ of ${ }^{241} \mathrm{Am}$.

The unused vault is locked and does not contain any known liquid; thus, there does not appear to be a credible scenario under which it would release radioactivity to the environment. This unit is not considered further in this document. 
WHC-EP-0480-1

This page intentionally left blank. 
WHC-EP-0480-1

\subsection{APPLICABLE REGULATIONS}

This chapter presents information on (1) the regulations governing effluent monitoring requirements for radioactive, nonradioactive hazardous, and mixed waste materials in effluents and (2) the applicable environmental standards and statutes. Table 3-1 contains a summary of applicable regulations.

\subsection{REgULATIONS PERTAINING TO EFFLUENT RELEASES}

Regulations pertaining to effluent releases at the Hanford Site have been developed by several regulatory agencies, including the EPA, DOE, Washington State Department of Ecology (Ecology), and the Benton, Franklin, and Walla Walla Counties Air Pollution Control Authority. Westinghouse Hanford has documented the policies for compliance in the Environmental Compliance Manual (WHC 1991b) because Westinghouse Hanford may enforce more restrictive requirements as a matter of policy.

To ensure the health and safety of the public, DOE-controlled facilities are required to monitor effluents that have the potential to contain regulated materials. Regulations pertaining to the monitoring and environmental surveillance requirements of effluents are typically based on the effluent release limits associated with the perceived risks these materials pose to the public. Monitoring requirements and associated limitations also may be based on best available technology (BAT) for liquid control technology, best available control technology for airborne control technology, and best practical control technology criteria. In addition, some monitoring requirements and associated limitations are based on environmental protection criteria, such as water quality-based discharge standards. The release limits for nonradioactive and radioactive effluents are designed to ensure that an acceptable level of risk to the public and the environment is not exceeded.

As documented in 40 CFR 61, National Emission Standards for Hazardous Air Pollutants (NESHAP) (EPA 1987a), effluent release limits for benzene and radioactive materials are based on limiting the risk to the public by limiting the potential dose to the maximally exposed member of the public. Similarly, for most nonradioactive materials, the risk to the public and the environment is controlled by limiting the quantities of the materials released.

In the case of nonradioactive effluents, monitoring requirements also may exist at the point of generation for the protection of the worker. To provide a safe workplace environment, monitoring of nonradioactive effluents is based on the level or quantity of material present at the point of generation within the facility. Currently, an accurate method for projecting the estimated source term released at the discharge point does not exist for the inventory at risk. Limited guidance is provided in 40 CFR, Part 61, Appendix D, Methods for Estimating Radionuclide Emissions (EPA 1987a). Although from a regulatory 
WHC-EP-0480-1

Table 3-1. Applicable Regulations and Standards.

\begin{tabular}{|c|c|c|c|c|c|c|c|c|c|c|c|c|c|}
\hline 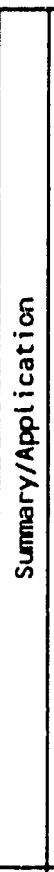 & 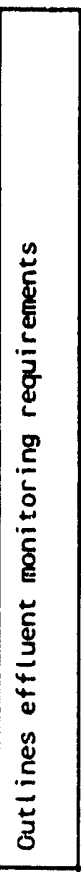 & 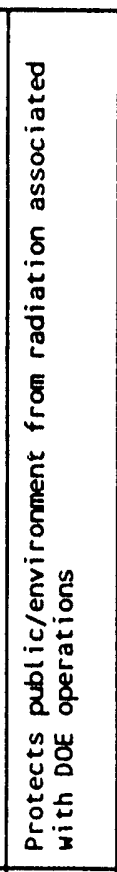 & 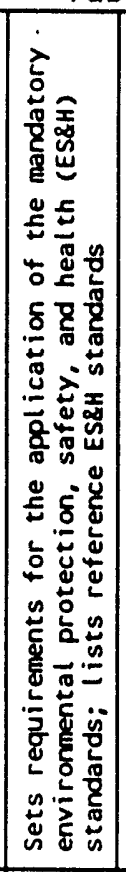 & 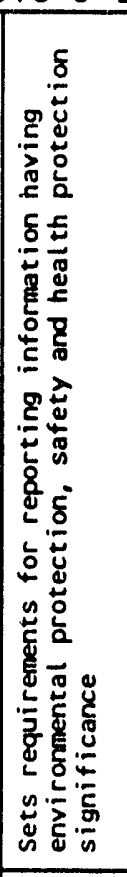 & 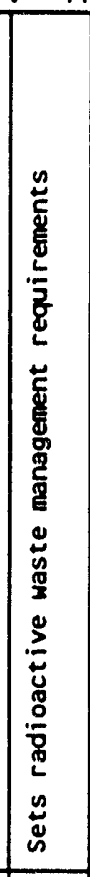 & 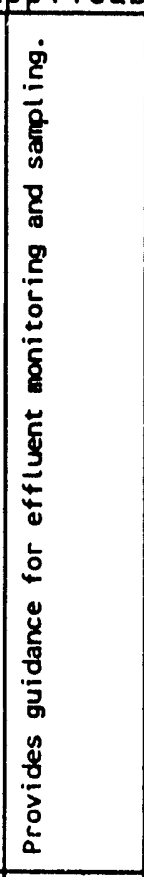 & 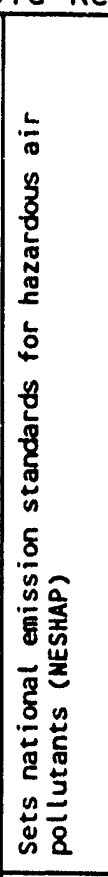 & 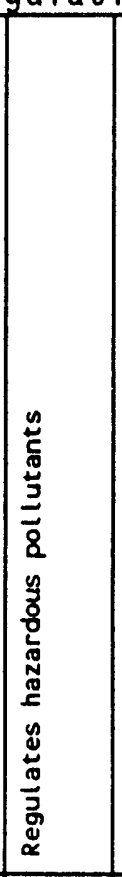 & 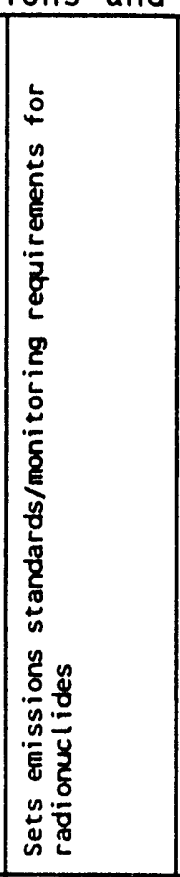 & 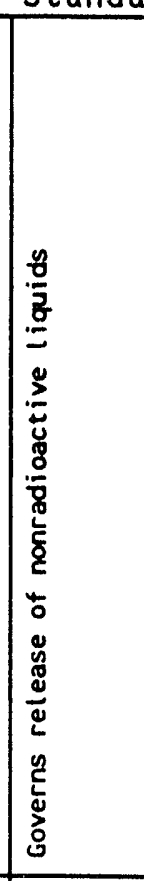 & 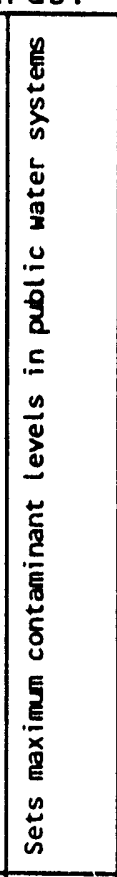 & 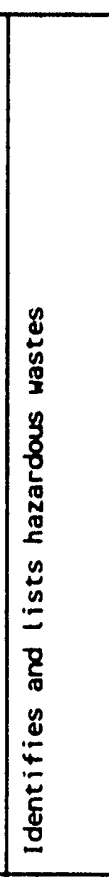 & 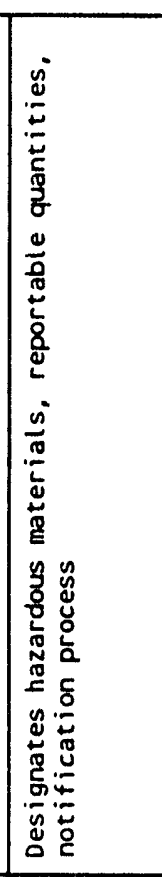 \\
\hline$\vec{\alpha}$ & $x$ & $\times$ & $x$ & $x$ & $x$ & $x$ & & & & & $x$ & & $x$ \\
\hline$\underset{\alpha}{\Phi}$ & $x$ & $x$ & $x$ & $x$ & $x$ & $x$ & $x$ & & $x$ & & & & $x$ \\
\hline$\vec{x}$ & $x$ & & $x$ & $x$ & $x$ & & & & & $x$ & $x$ & $x$ & $x$ \\
\hline $\mathbb{x}$ & $\times$ & & $x$ & $x$ & $x$ & & $x$ & $x$ & & & & & $\times$ \\
\hline & 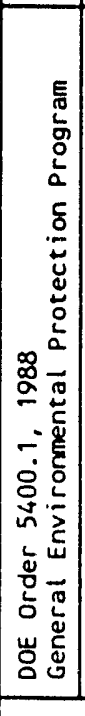 & 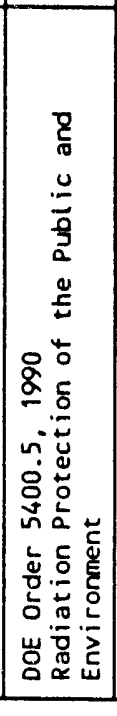 & 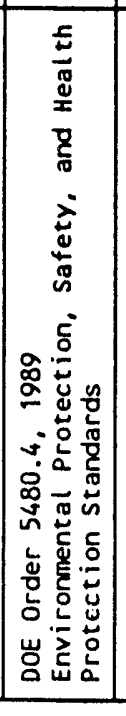 & 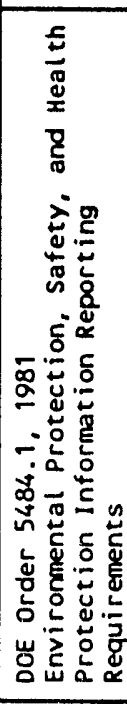 & 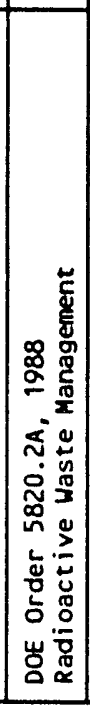 & 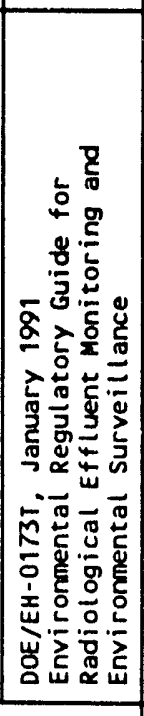 & 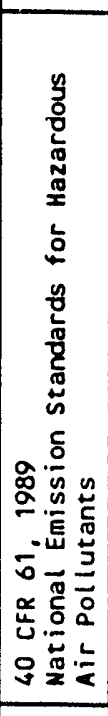 & 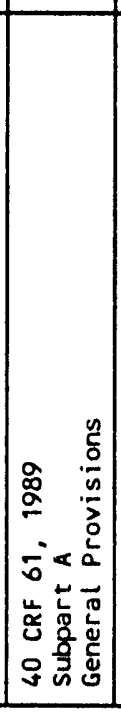 & 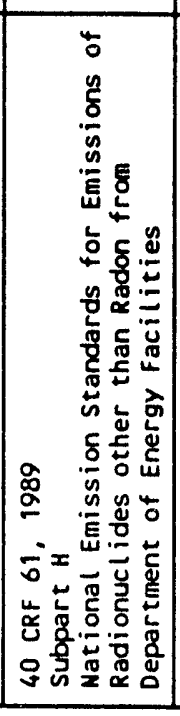 & 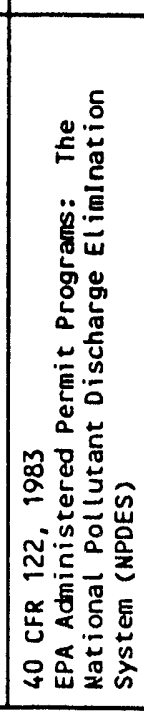 & 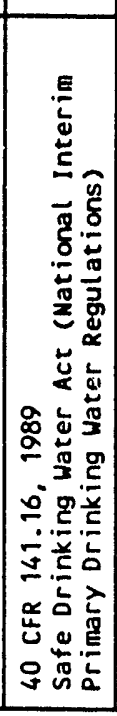 & 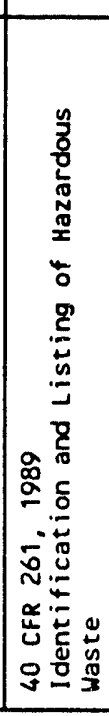 & 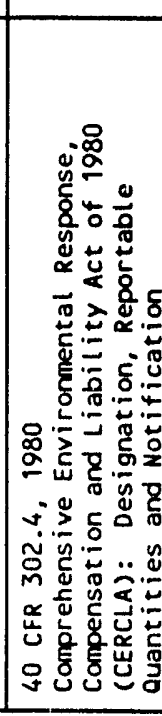 \\
\hline & 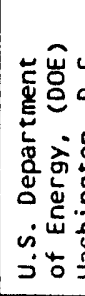 & & & & & & 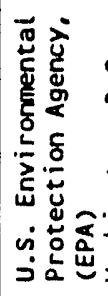 & & & & & & \\
\hline
\end{tabular}


Table 3-1. Applicable Regulations and Standards.

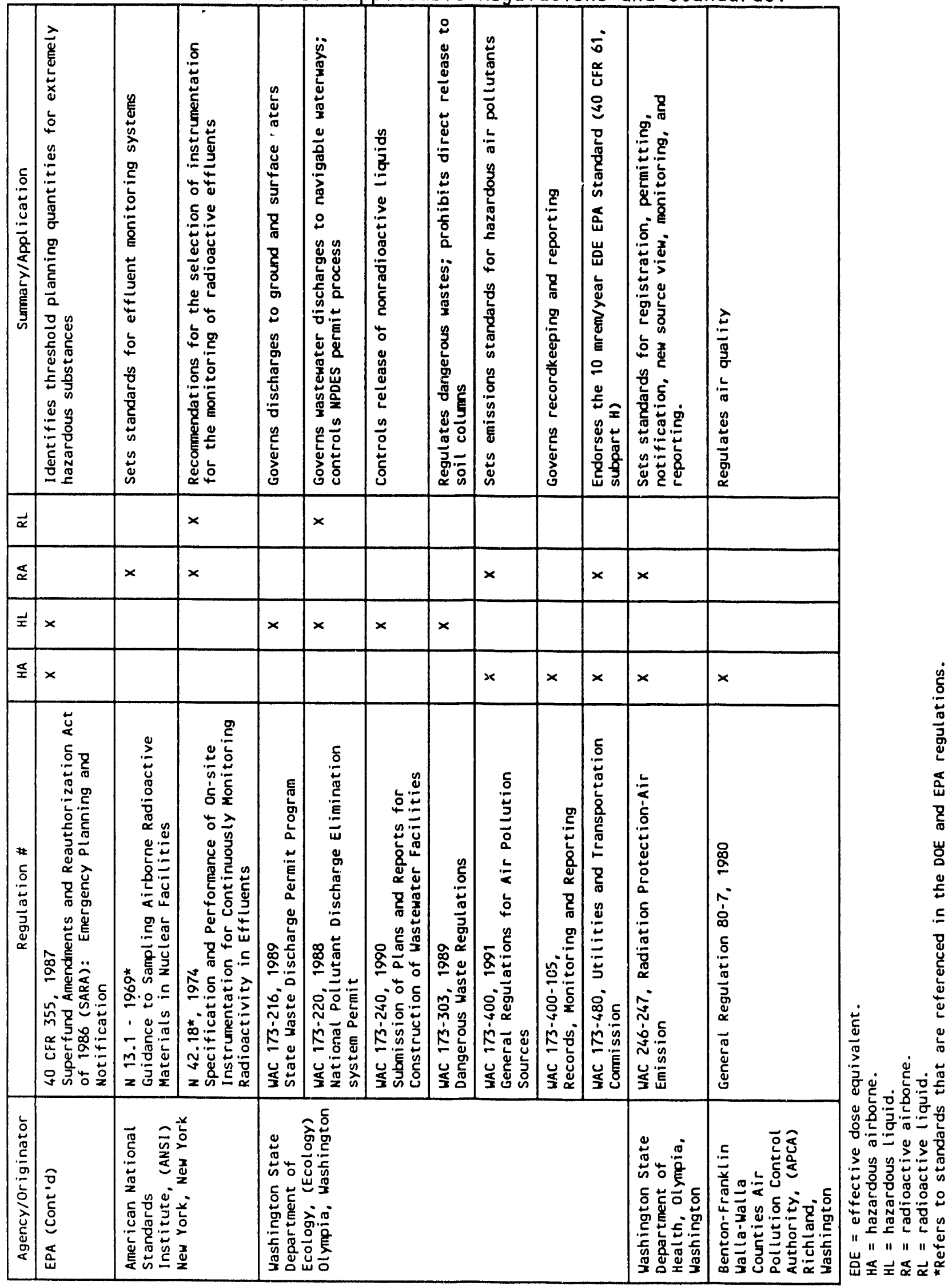


standpoint this guidance applies specifically to radionuclide emissions in select circumstances, some of the resuspension fractions and assumptions in 40 CFR 61, Appendix D, may provide a technical basis for similar calculations for hazardous wastes or effluents containing hazardous wastes. Any alternative use of Appendix $D$ must receive prior approval of EPA.

It is important to review the dose limits to the public from operations at DOE-controlled facilities. The EPA has promulgated a revision to NESHAP, mandating that radionuclide air emissions from each DOE site will not cause any individual (maximally exposed individual) to receive a dose greater than $10 \mathrm{mrem} / \mathrm{yr}$ EDE. A single site or facility, as used here, means all the buildings, structures, and operations within one contiguous site. For example, the entire DOE facility at the Hanford Site must meet the $10 \mathrm{mrem} / \mathrm{yr}$ EDE standard rather than each building meet the $10 \mathrm{mrem} / \mathrm{yr}$ EDE standard. In DOE Order 5400.5, paragraph II.1.b (DOE 1990a) the dose from airborne radioactivity is limited to $10 \mathrm{mrem}$ EDE, which is consistent with the EPA Standard.

Dose limits to the public dictate effluent monitoring requirements. The DOE Order 5400.5 (Chapter II, Paragraph 1.a) (DOE 1990a) presents limits for exposure of the public to radioactive materials as a consequence of DOE activities from all DOE sources of radiation. The order states that DOE activities will not cause any member of the public to receive an EDE greater than 100 mrem in a year. The order also alerts the reader to the fact that DOE must comply with legally applicable requirements, inçluding 40 CFR 61 (EPA 1987a) for airborne emissions. Doses due to ${ }^{220} \mathrm{Rn},{ }^{222} \mathrm{Rn}$, and the ir respective decay products are specifically excluded from the NESHAP dose standard; however, they are regulated by DOE Order 5400.5 .

To demonstrate compliance with the dose limit requirements using effluent sampling techniques, evaluations of potential doses to individuals through the air pathway will be evaluated using only AIRDOS/RADRISK (Moore et al. 1979) or other computer codes or models specifically approved by EPA, as specified in NESHAP (EPA 1987a). Compliance al so may be demonstrated through environmental measurements using approved techniques and calculation of estimated doses to individuals assumed to reside at the point of maximum annual air concentration.

\subsection{REGULATIONS PERTAINING TO MONITORING REQUIREMENTS AT U.S. DEPARTMENT OF ENERGY FACILITIES}

The monitoring requirements for effluents resulting from the operation of DOE-controlled sites can be presented in two categories. These categories relate to the effluent release pathway; that is, whether the release pathway is airborne or liquid. In addition, information on the monitoring requirements is presented according to whether the effluent is radioactive, nonradioactive, hazardous, or nonhazardous. Before presenting this material, however, it is useful to review in detail the requirements outlined by DOE for FEMPS. 
WHC-EP-0480-1

\subsubsection{U.S. Department of Energy Facility Effluent Monitoring Plan}

Requirements for a FEMP are provided in DOE Order 5400.1, General Environmental Protection Program (DOE 1988a). The order provides specific information in Chapter IV on the requirements for effluent monitoring systems and programs at the Hanford Site. Environmental monitoring requirements differ between new and existing facilities. For a new facility with the potential for adverse impact on the environment, an environmental survey must be conducted before actual start-up. The survey will establish background levels of radioactive and toxic poliutants, characterize pertinent environmental and ecological parameters, and identify potential pathways for human exposure or environmental impact as a basis for determining the nature and extent of the subsequent routine operational effluent and environmental monitoring program.

Radioactive and nonradioactive pollutant effluents reieased at the Hanford Site will be monitored to determine compliance with the DOE Orders 5400.1 (DOE 1988a), 5400.5 (DOE 1990a), 5484.1 (DOE 1981) and 5480.11 (DOE 1988b). The monitoring is performed (1) to evaluate the effectiveness of effluent treatment and control; (2) for radioactive material inventory purposes; and (3) to determine compliance with all DOE, EPA, State, and local requirements pertaining to effluents and pollutant impact on the environment. Radioactive material released to onsite waste treatment or disposal systems will be monitored to assess the effectiveness of treatment and control and to provide a qualitative and quantitative annual summary of the radioactive material released.

The DOE Order 5400.1 (DOE 1990a) also provides guidance on effluent monitoring. As a general rule, monitoring should be conducted in a manner that provides accurate measurements of the quantity and/or concentration of liquid and airborne pollutants in effluents as a basis for (1) determining compliance with applicable discharge and effluent control limits, including self-imposed administrative limits designed to ensure compliance with in-plant operating limits, effluent standards or guides, and environmental standards and guides; (2) evaluating the adequacy and effectiveness of containment and waste treatment and control, as well as the efforts toward achieving levels of radioactivity that are as low as reasonably achievable (ALARA), considering technical and economical constraints; and (3) compiling an annual inventory of the radioactive material released in effluents and onsite discharges.

Collected effluent monitoring data should reflect as accurately as possible the volume, rate of discharge, and content of the effluent at the point of discharge. Effluent monitoring data pertaining to the release of nonradioactive pollutant material should include the total quantity (amount). Effluent monitoring data pertaining to the release of radioactive material should include the total activity (number of curies) released in airborne and liquid effluents and the specific radionuclides comprising a significant portion $(>10 \%)$ of the radiation dose. Although exceptions exist, this requirement indicates that the measurement should be made at the point of discharge. An exception occurs when a portion of the effluent stream close to the point of generation can be monitored to provide a more accurate estimate of the hazardous material being released from the facility. 
WHC-EP-0480-1

Effluents should be monitored at the point at which the applicable standards apply. For example, onsite discharges may be monitored at the waste treatment and disposal system; effluents may be monitored at the point after all treatment and control (including retention and decay) have occurred. In many cases, the monitoring location is specified in the discharge or operating permit.

The sampling method and frequency should be determined by considering the purpose or need for the data collected. Data are collected to evaluate the effectiveness of waste treatment and control, to demonstrate compliance with operating limits of applicable effluent or performance standards, and to compile and trend effluent characteristics. Continuous or proportional sampling is recommended and may be required where there is significant variation in the concentrations and mixtures of potential pollutants in the effluent stream. Periodic sampling may be adequate when the concentrations and mixtures are reasonably constant, and there is minimal likelihood of unusual variations. Similarly, proportional sampling may be necessary when effluent flowrates fluctuate, whereas a representative grab sample may suffice for batch discharges. The method of sampling is usually specified in the applicable regulation or permit.

For the purpose of reporting radiological data, gross radioactivity measurements generally are inadequate. They can be appropriate when (1) gross radioactivity releases are a small fraction of the offsite Radioactivity Concentration Guides for "unidentified mixtures" and are of no health or environmental significance; (2) the relative concentrations of specific radionuclides are so well known by other means that gross radioactivity measurements are truly indicative of the activity being released; or (3) the activity of waste streams is so low as to preclude specific nuclide measurements.

Radioactive effluents and onsite discharge monitoring and reporting must be adequate to provide an annual average concentration and an annual summary of the quantities of radioactive materials released. The summary should be complete to the extent that all significant releases are reported. It is required, therefore, that the annual average flow and pollutant concentration be determined for each waste stream.

The EPA regulations pertaining to the release of hazardous substances from DOE facilities are presented in 40 CFR 302, Designation, Reportable Quantities, and Notification (EPA 1985a). This regulation, in accordance with Sections 101(14) and 102(a) of the Comprehensive Environmental Response, Compensation, and Liability Act of 1980 (CERCLA), designates those substances in the statutes of CERCLA, identifies RQs of those substances, and sets forth the notification requirements for releases of these substances. This regulation also sets forth $\mathrm{RQ}$ s for hazardous substances designated under Section 311 (b) (2)(A) of the Clean Water Act of 1977.

\subsubsection{Airborne Effluents}

Airborne emissions of radioactive materials from DOE-controlled facilities at the Hanford Site are subject to the regulations of EPA. The primary regulation is 40 CFR 61 (NESHAP). The list of hazardous air 
pollutants regulated under NESHAP (EPA 1987a) is provided in subpart A, "General Provisions." The specific emissions standards and monitoring requirements for radionuclides are contained in Subpart H, "National Emission Standards for Emissions of Radionuclides Other Than Radon From Department of Energy Facilities," of the proposed 40 CFR 61. Subpart H standards cover all DOE operations that emit radionuclides (other than radon) to the air, except for facilities subject to 40 CFR 191, Subpart B (disposal of spent nuclear fuel and high-level and TRU radioactive wastes) (EPA 1985b) and 40 CFR 192 (uranium and thorium mill tailings) (EPA 1983).

Subpart $H$ of the NESHAP presents detailed requirements for emissions monitoring and test procedures, compliance and reporting, record-keeping requirements, and exemptions from the reporting and testing requirements of 40 CFR 61. Radionciclide emission rates from stacks and vents must be measured at all release points that have the potential to discharge radionuclides into the air in quantities that could cause an EDE in excess of $1 \%$ of the standard. The potential to discharge radionuclides must be based on the discharge from the effluent stream that would result if all pollution-control equipment did not exist, but facility operation(s) was otherwise normal. For release points that have a potential to release radionuclides into the air but have effluents below the continuous monitoring standard, periodic confirmatory measurements must be made to verify low emissions. Furthermore, all radionuclides that can contribute greater than $10 \%$ of the potential EDE for each release point must be measured. With prior EPA approval, alternative methods to the one described (including process knowledge) can be substituted for measurement to determine the emission levels of individual radionuclides.

Subpart H, Section 61.93 specifies the monitoring for determining radionuclide emission rates. These requirements include sampling points, appropriate sampling methods, flowrate determinations, frequency of sampling, analytical methods, quality assurance procedures, or other procedures approved by EPA. Direct measurement of air concentrations of radionuclides at the receptor point is acceptable if the criteria in Section 61.93(b)(5) are met. These criteria include continuous monitoring of released radionuclides, satisfactory detection limits, quality assurance, and prior EPA approval.

40 CFR 61 , Subpart $H$ requires that $p l a n t s$ continuously monitor their operations and keep records of the results of their monitoring onsite for 5 years. Facility operators will have to assess, on an annual basis, that no changes in operations that would require new testing have occurred. Although the report is based on the calendar year, the emission limit applies to any period of 12 consecutive months.

Additional EPA requirements on hazardous substances are contained in 40 CFR 302.4 (EPA 1985a). This regulation provides information on RQs of nonradioactive hazardous substances. Unlisted hazardous substances designated by 40 CFR 302.4 are regulated in accordance with the EPA-defined toxicity of the contaminant.

Several DOE orders provide requirements for monitoring radioactive and nonradioactive airborne effluents from DOE facilities at the Hanford Site. These orders state that DOE-controlled facilities must comply with 40 CFR 61 (EPA 1987a). The two principal orders are DOE Order 5400.5, Radiation 


$$
\text { WHC-EP-0480-1 }
$$

Protection of the Public and the Environment (DOE 1990a), and DOE Order 5400.1, Chapter IV, Environmental Monitoring Requirements (DOE 1988a).

Airborne emissions from DOE-controlled facilities that have the potential for radioactive contamination must be monitored in accordance with the requirements of DOE Order 5400.1 (DOE 1988a) and DOE Order 5400.5 (DOE 1990a).

In Washington State, airborne effluents are regulated by the Washington Clean Air Act (WAC 173-400-075) (WAC 1976). General regulations for air pollution sources are presented in WAC 173-400 (Ecology 1991b), including emission standards for sources emitting hazardous air pollutants in WAC 173-400-075.

The WAC 246-247, Radiation Protection Air Emissions, specifies new source review, notification, registration, and permitting requirements associated with any source of radioactive air emissions in Washington State, including those on the Hanford Site. One requirement listed in WAC 246-247 is the semiannual (twice yearly) reporting of emissions from each registered stack or vent onsite. By agreement with the Washington State Department of Health, only annual reporting is required.

The WAC 173-480, Ambient Radionuclides, defines maximum allowable levels for radionuclides in the ambient air and defines required levels of control emissions. The regulation was last revised May 7, 1986, and is enforced by Ecology.

While both the WAC 246-247 and 173-480 list outdated maximum EDE standards, each contains a caveat stating that anymore stringent Federal standards take precedence over the EDE standard specified by the WAC. Therefore, each effectively endorses the $10 \mathrm{mrem} / \mathrm{yr}$ EDE standard of the 40 CFR 61 , subpart $H$.

The U.S. Department of Energy, Richland Field Office (RL) contractor policies for radioactive airborne releases are discussed in WHC-CM-7-5 (WHC 1991b). This manual references the applicable regulations governing the monitoring of radioactive airborne effluents in NESHAP. Other regulations, including 40 CFR 52 (EPA 1989a), and DOE Orders 5400.1 (DOE 1988a), 5400.5 (DOE 1990a), and 5484.1 (DOE 1981), state that DOE facilities must comply with the requirements set forth in the NESHAP.

Currently, there are no other treatment, storage, and disposal facilities at the 222-S Laboratory which would contain airborne emissions subject to the Federal Register airborne requirements.

\subsubsection{Liquid Effluents}

Requirements limiting the exposure of the public to radioactive materials from DOE-controlled activities through the drinking water pathway are presented in DOE Order 5400.5, Chapter II, Paragraph 1.d (DOE 1990a). Although the radiological criteria of the public community drinking water standards of 40 CFR 141 (EPA 1985C) are not applicable to DOE-operated 
drinking water systems, it is the policy of DOE to provide an equivalent level of protection for all persons consuming the water from a drinking water supply operated by or for DOE. These systems will not cause any person consuming the water to receive an EDE greater than $4 \mathrm{mrem} / \mathrm{yr}$, excluding naturally occurring radionuclides. In addition, DOE facility operators will ensure that the 1 iquid effluents from $20 \mathrm{E}$ activities will not cause private or public drinking water systems downstream of the facility discharge to exceed the drinking water radiological limits of 40 CFR 141 (EPA 1985C).

The dose limit is consistent with the drinking water criteria in 40 CFR 141. The dose limit is the EDE to an individual whose exclusive source of drinking water contains a radionuclide or a mixture of radionuclides at a level of $4 \%$ of the appropriate derived concentration guide $J C G$ ) value. The maximum contaminant levels in piblic water systems are found in 40 CFR 141.15 (generally radium and alpha emitters) and in 40 CFR 141.16 (beta and gamma emitters) (EPA 1985c).

Liquid effluenis from DOE-controlled facilities that have the potential for radioactive contamination must be monitored in accordance with the requirements of DOE Orders 5400.1 (DOE 1988a) and 5400.5 (DOE 1990a). Facility operators must provide adequate monitoring of liquid waste streams to (1) demonstrate compliance with the applicable requirements of DDE Order 5400.5, Chapter II: (2) quantify radionuclides released from each discharge point; and (3) alert affected process supervisors of upsets in processes and emissions controls.

Depending on where a liquid effluent (wastewater) is discharged, certain regulations apply. These regulations are implemented through issuance of permits by Federal, State, and/or local agencies. It is the responsibility of the facility, through RL, to apply for the permit appropriate to the effluent being discharged. Before applying for any permits, the applicant must know the sources of its wastewater discharges and where the wastewater is being discharged. The following regulations app?y, based on where the wastewater is discharged.

- Wastewater discharged to a Publicly Owned Treatment Works (POTW) is subject to Federal regulations found in 40 CFR 403 to 471 (EPA 1990) and may also be subject to local regulations and limitations. Fermits for such discharges are obtained from the local sewerage agency into which the effluent is discharged, or in some cases, from the Statn. DOE Order 5400.5, paragraph II.3.d (DOE 1990a), sanitary sewage also addresses discharges to sewage systems.

- Wastewater discharged into a nal:igable waterway is subject to state of Washington regulations (WAC 173-220) (Ecology 1990a) under the National Pollutant Discharge Elimination System NPDES). The EPA issues NPDES permits for such discharges.

- Washington State controls discharges to ground and surface waters of the state under WAC 173-216 (Ecology 1990b) and issues permits for such discharges. A permit of this type would be necessary for any discharges to land that could infiltrate to groundwater. 
Each type of discharge permit identified above will typically contain discharge limitations and monitoring requirements. However, the limitations and monitoring requirements will vary, depending on the source and type of wastewater being discharged. For instance, discharges to a POTW will be subject to pretreatment standards, which are based on the production process generating the wastewater for those processes categorized by EPA. Categorical processes are identified in 40 CFR Parts 403-471 (EPA 1990). Specific limitations, monitoring, and reporting requirements have been promulgated for each categorical process. In addition to EPA's requirements, the state and local sewerage agency may impose additional limitations, monitoring, and reporting requirements. Discharges to a navigable waterway also will be subject to certain standards, based on the industrial process generating the wastewater. Certain additional limitations also are typically imposed in the NPDES permit. In all cases, the specific pollutants to be monitored and the frequency of monitoring and reporting will be based on the applicable regulations and the language of the permit.

Because the Hanford Site has 33 separate liquid discharges, the Hanford Federal Facility Agreement and Consent Order, al so known as the Tri-Party Agreement (TPA), has established milestones, as part of the Liquid Effluent Study Program, for compliance plans of liquid discharges to land that could infiltrate to groundwater (Ecology et al. 1990). Sample analysis plans are required for each Hanford Site liquid effluent stream. A Sampling Analys is Plan (Warwick 1992) for the 222-S Laboratory Complex Wastewater to the 216-S-26 crib was prepared as part of the TPA milestone.

The $\mathrm{RL}$ contractor policies for nonradioactive and radioactive liquid effluents are discussed in WHC-CM-7-5 (WHC 1991b). This manual describes current contractor requirements for monitoring and restricting liquid $e^{r}$ fluents. Applicable requirements are discussed in Section 3.4 of this document.

\subsubsection{Hazardous Mixed Wastes}

There are currently no regulations pertaining to mixed waste in effluents. Radioactive and hazardous contaminants in effluent streams are handled as individual components in effluent regulations and in effluent monitoring.

The RL contractor policies on mixed waste are presented in Section $\mathrm{J}$ of Westinghouse Hanford's Environmental Compliance Manual, WHC-CM-7-5 (WHC 1991b).

\subsection{STANDARDS/REFERENCES}

The DOE Order 5480.4, Environmental Protection, Safety, and Health Protection Standards (DOE 1984), presents a listing of mandatory and good practice environmental standards. 


\subsection{WESTINGHOUSE HANFORD EFFLUENT MONITORING REQUIREMENTS}

Westinghouse Hanford's policy for monitoring effluents is presented in WHC-CM-7-5 (WHC 1991b). The Westinghouse Hanford manual contains some requirements more restrictive than those found in the regulations.

The purpose of the WHC-CM-7-5 is to establish guidelines to be used by Westinghouse Hanford that (1) protect the environment from radioactive materials and other dangerous substances under Westinghouse Hanford jurisdiction; (2) protect people from radionuclides and other dangerous substances in the environment; and (3) provide a tool to be used in conjunction with applicable DOE Orders and other pertinent Federal, State, and local laws, rules, and regulations promulgated for environmental protection in accordance with the policy defined in WHC-CM-1-1 (WHC 1988a).

The following sections in WHC-CM-7-5 (WHC 1991b) address the regulations applicable to this FEMP: (1) general provisions (Part $A$ ), (2) releases to the environment (Part B), (3) nonradioactive airborne effluents (Part C), (4) radioactive airborne emissions (Part $D)$, (5) nonradioactive liquid discharges (Part E), (6) radioactive liquid (Part F), (7) dangerous waste control (Part I), and (8) mixed waste (Part J).

\subsection{FACILITY REQUIREMENTS FOR ORGANIC EMISSION STANDARDS}

The EPA requires that facilities operating under a Subtitie $C$ Permit [refer to 40 CFR, Part 261.3 (EPA 1987b)] must meet specific organic emission standards. These standards include hazardous waste treatment, storage, and disposal (TSD) facilities. Included are organic emissions from recycling units that do not require a RCRA permit, but are part of a TSD facility that is required to have a Subtitle $C$ Permit. If hazardous waste management facilities have an annual average total organic concentration of 10 parts per million by weight or greater, the facility is required to reduce the total organic emissions from all processes to below $3 \mathrm{lb} / \mathrm{h}$ or 3.1 tons/yr or to install and operate a control device that reduces the total organic emissions by $95 \%$. Facilities that are in compliance are not required to install control devices or monitor emissions if it can be shown that organic emissions will never exceed the established limits. 
WHC-EP-0480-1

This page intentionally left blank. 


\subsection{IDENTIFICATION AND CHARACTERIZATION OF EFFLUENT STREAMS}

Individual effluent streams are organized here in two categories: liquid effluents and gaseous emissions. Each stream is briefly described below, and the potential for an environmental release under normal operating conditions and upset conditions is assessed for radioactive and hazardous chemical release.

For hazardous chemicals, the upset condition considered was the inadvertent or unknowing introduction of one container of a given inventory of chemicals into a sink, hood, or floor drain. In order to be conservative, it was assumed that the largest available container was spilled or poured down the drain over a 24-h period.

Radionuclide emissions were estimated from monitoring data, if available. A factor of 3,000 was applied to airborne emissions to simulate a loss of HEPA filtration.

\subsection{LIQUID EFFLUENTS}

Five routine or potential liquid effluent streams were identified under routine and upset conditions from the site visit and documents provided by Westinghouse Hanford staff. During normal operation, it is unlikely that any would contain CERCLA RQs of dangerous substances or be designated as a hazardous waste. However, consideration of upset conditions has identified the potential for CERCLA RQs to be discharged and for the stream to be designated as a hazardous waste. This, coupled with the fact that radionuclides are discharged to the soil column, indicates a need for a FEMP.

\subsubsection{2-S Laboratory Wastewater}

This waste stream consists of the liquid effluent from the 222-S Building (Figure 4-1). Included in this effluent are steam condensate, vacuum-pump cooling water, laboratory sink drainage, cold-tunnel sump drainage, and overflow from the supply fan air washers. This effluent is discharged into the 207-SL Retention Basins. The influent from the 222-S Laboratory is sampled via a flow totalizer and proportional grab sampling system. Samples are analyzed once per day or before discharge. If the proportional sampler is inoperable, a grab sample of the effluent in the basin is obtained and analyzed before discharge. The sample is analyzed for $\mathrm{pH}$, TOC, nitrate, total alpha, and total beta. The analys is is compared to WHC-CM-7-5 limits for discharge (WHC 1991b). If within the limits, it is discharged to the 216-S-26 Crib. If the sample exceeds limits, the effluent can be sent to the 219-S Waste Treatment Building and/or to Tank Farms for storage in the double-shell tanks. Transfers from 207-SL to the 219-S tanks would be by overland piping. Transfers from the 219-S Waste Handling Facility to Tank Farms currently would be by tank trailer truck or by underground lines. 
Figure 4-1. 222-S Laboratory Coolant and Condensate Flow Diagram.

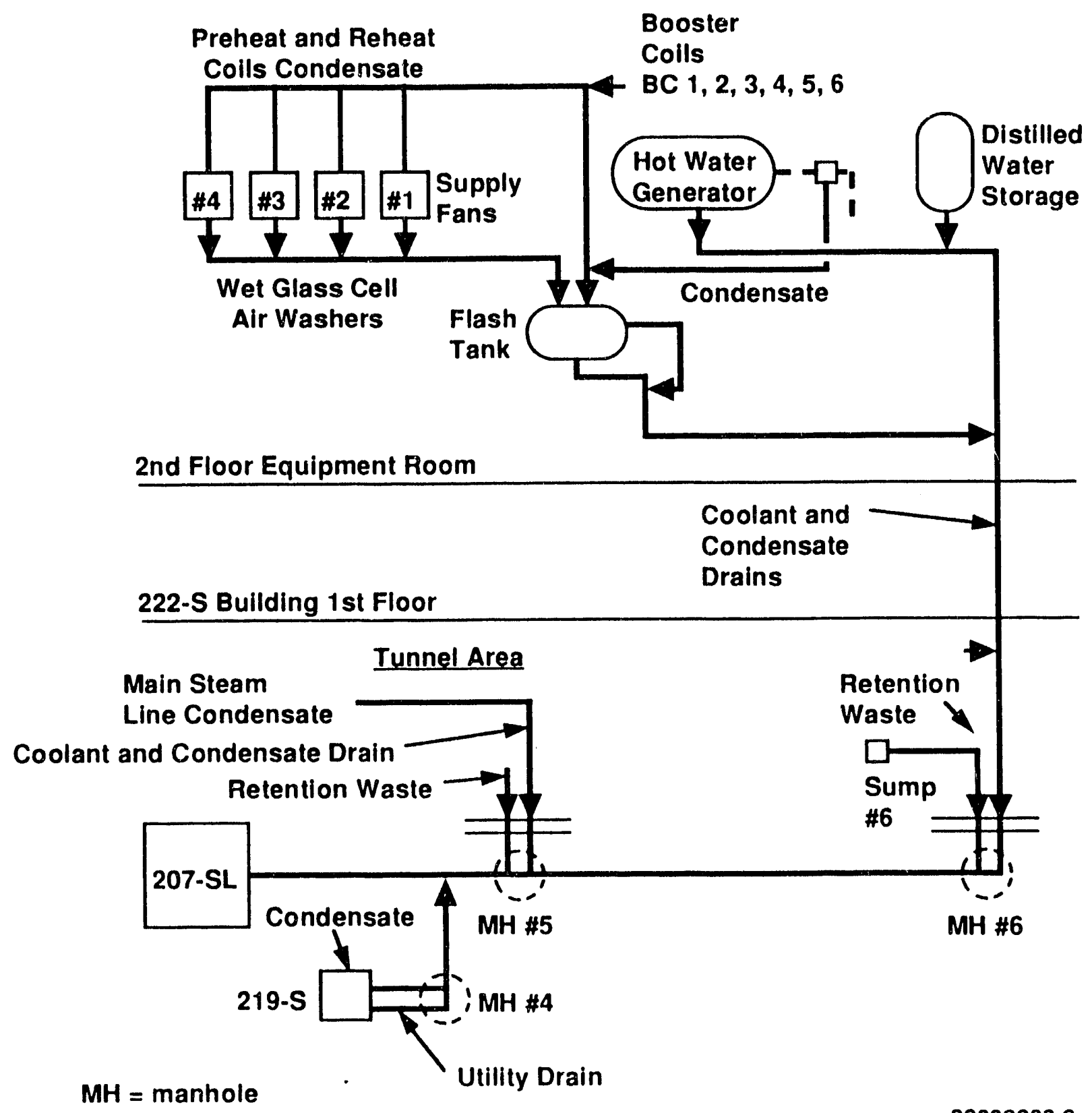


This waste stream is not currently regulated with regard to hazardous chemicals. During an earlier assessment, it was observed that administrative controls are in place (e.g., signs at sink drains) to prevent discharge of dangerous wastes to this stream. Operating procedures are in place to prohibit disposal of liquid wastes to laboratory sinks and drains and it was noted that these procedures specifically state that hazardous chemicals may not be disposed of io this stream.

The FEMP Determination (WHC 1991d) lists the potential discharges to the soil column (discharge point 207-SL to the 216-S-26 Crib) for radionuclides at the routine monitored levels and for hazardous chemicals during upset conditions. The method of calculation for the hazardous chemicals under upset conditions was as follows: It was assumed that the largest container of chemical in the inventory was introduced to the wastewater stream. The released amount of chemical was then compared to the final RQ levels of 40 CFR 302, Table 302.4 (EPA 1985a). No chemicals were identified that had the potential for release above the EPA RQ. The regulations regarding nonradioactive liquid discharges require that releases discharged to groundwater should not exceed maximum contaminate levels in Appendix $B$ of WHC-CM-7-5 (WHC 1991b).

Also found in 40 CFR 302, Table 302.4 (EPA 1985a), are RQs of characteristic waste. These wastes are designated as such because of properties of ignitability, corrosivity, reactivity, or toxicity. Toxicity characteristics of the waste are defined by the list of compounds in Table 302.4 and the regulatory limits elaborated in 40 CFR 261.24 (EPA 1987b). The amount of chemical that could be released under the upset conditions was assumed dissolved in the entire daily effluent from the 222-S Laboratory $(7,000 \mathrm{gal})$. If the resultant concentration of chemical was greater than the toxicity characteristic leaching procedure (TCLP) maximum concentration of contaminants for the toxicity characteristics (40 CFR 261.24, Table 1), then the entire 7,000 gal of wastewater was designated appropriately and compared against the RQ levels in Table 302.4 and lists of prohibited discharges to 1 and as discussed in WAC 173-303-140 (Ecology 1991a) and 40 CFR 268 (EPA 1987c). A number of chemical compounds met these criteria. These compounds are listed in the FEMP determination (discharge point 207-SL to the 216-S-26 (rib). Also listed is the specific chemical, element, or compound, and the amount used in the calculations. Based on these upset conditions, there are effluents that potentially exceed RQs and/or would be designated as a hazardous waste. The current monitoring parameters for $\mathrm{pH}$, nitrate, and TOC would detect some of these compounds. A FEMP is required, based on trie potential for exceeding CERCLA RQs and discharging a hazardous waste.

A consideration of the radioactive portion of the effluent indicates that (1) radionuclides have been discharged to the ground in the past and (2) the effluent meets the definition of a normally contaminated effluent (Brown et al. 1990). A FEMP is required, based on the criteria that any radionuclide discharged to the ground must be monitored. In addition, the potential exists for discharge in excess of Westinghouse Hanford administrative control value (ACV) (WHC-CM-7-5, Part F) (WHC 1991b). 
WHC-EP-0480-1

\subsubsection{2-SA Laboratory Wastewater}

This waste stream consists of the liquid effluent from the 222-SA Building. Included in this effluent are water-purification-system back-flush water, water from sink and hood drains, and discharges from the glass washer. Administrative controls are in place (e.g., signs at sink drains) to prevent discharge of dangerous wastes to this stream. Operating procedures for disposal of liquid wastes to laboratory sinks and drains specifically state that hazardous chemicals may not be disposed of to this stream. Radionuclides are not used in the building; thus, this effluent is discharged directly to the 216-S-26 Crib without monitoring or sampling (Figure 2-4).

The RCRA Part A Permit application for the 216-S-26 Crib was withdrawn because there is no evidence that dangerous wastes were discharged to this crib. Thus, during upset conditions where administrative controls prohibiting sink disposal of chemicals have failed, there is a potential for any of the chemicals in the 222-SA inventory to be released into the soil column. A comparison of the 222-SA SARA Chemical Inventory against the RQ in 40 CFR 302, Table 302.4 (EPA 1985a) showed that there were no chemicals that had the potential for release under normal or upset conditions in excess of Table $302.4 \mathrm{RQs}$.

There are ten other chemicals that could, under upset conditions, contaminate the 222-SA chemical wastewater effluent such that the entire 1,000 gal estimated daily volume becomes a dangerous waste. For example, a release of $100 \mathrm{~g}$ of cadmium nitrate would result in the effluent having a daily average concentration of $26 \mathrm{p} / \mathrm{m}$. This is well above the $1 \mathrm{p} / \mathrm{m}$ that would designate the effluent a dangerous waste under 40 CFR 261 (EPA 1987b) or WAC 173-303-090 (Ecology 1991a). Thus, the effluent to the 216-S-26 Crib $(1,000 \mathrm{gal}, 8,370 \mathrm{ib})$ would be far in excess of the one pound $R Q$ allowed for TCLP or extraction procedure toxic waste in Table 302.4 (EPA 1985a) and would violate land-disposal prohibitions of WAC 173-303-140 (Ecology 1991a) and 40 CFR 268 (EPA 1987c). Four other metals, four chlorinated solvents, and pyridine would create a similar effect with regard to the TCLP waste designation of toxicity. These compounds are listed in the FEMP determination (discharge point $216-\mathrm{S}-26 \mathrm{Crib}$ ). Based on this assessment, there are compounds that, if introduced into the effluent, would cause an $R Q$ to be exceeded and would constitute the discharge of hazardous waste into the environment in violation of WAC 173-303, 40 CFR 302, and 40 CFR 268. A FEMP is required for this effluent stream.

\subsubsection{1-S Stack Fan House Cooling Water}

Cooling water and steam condensate from the 291-S Facility emergency exhaust fan is routed directly to the 207-SL Retention Basins discharge box (Figure 2-4). Therefore, it bypasses the sampling procedure performed on 222-S influents and is discharged directly to the 216-S-26 Crib. Based on estimates of usage and flowrate (WHC 1990a), the maximum contribution is about $14,000 \mathrm{gal} / \mathrm{yr}$. 
The condensate is not routinely or potentially contaminated with hazardous materials (WHC 1990a). There is also no credible potential for radioactive contamination of the condensate under routine or upset conditions; therefore, a FEMP is not required.

\subsubsection{The 219-S Waste Handling Facility}

The 219-S Waste Handling Facility collects radioactive and mixed liquid waste generated by 222-S Laboratory operations. Overflow and drain 1 ines from the caustic. tank (tank TK-201) are routed to tank TK-101. There is no credible potential for a release to the environinent of radioactive or mixed waste effluents under routine operating conditions.

Two potential upset conditions present the opportunity for a liquid effluent release to the environment: (1) a failure of valving or pipe from a tanker truck to the outside valve of tank TK-201 would result in spilling caustic, which is a characteristic waste because of corrosivity; and (2) a failure of valving, fitting, or pipe downstream from the tank TK-102 outlet and pump used to transfer waste to the tank trucks, which transport the radioactive hazardous waste from the 219-S tanks to the Tank Farm, would result in an environmental release to the ground via the French drain system.

Under upset condition (1) it was assumed that there would be about $60 \mathrm{gal}$ of caustic available for release due to line drainage and/or two minutes of undetected pumping to or from a tank truck at $20-30 \mathrm{gal} / \mathrm{min}$. The $60 \mathrm{gal}$ would not exceed the 1,000 pound $\mathrm{RQ}$ for $\mathrm{NaOH}$, but would exceed the $100 \mathrm{lb} \mathrm{RQ}$ for a waste with $\mathrm{pH}>12.5$. [See FEMP determination (WHC 1991d).] The spill would enter the French drain system on the north side of the building.

Under upset condition (2) it was assumed that there would be an undetected disconnect during tank truck loading that persists for two minutes. The flowrate is assumed to be $15 \mathrm{gal} / \mathrm{min}$ and the tanks are assumed to contain the maximum of $150 \mathrm{~g}$ fissile material in the entire working volume of the three tanks $(8,460 \mathrm{gal})$. The ${ }^{239} \mathrm{Pu}$ was chosen for the calculation. The waste in the tanks has been analyzed and was found to be both corrosive $(\mathrm{pH}>12.5)$ and TCLP toxic for lead and mercury. [See FEMP determination (WHC 1991d).]

Based upon these conditions, radioactivity would be released to the soil and a release of TCLP toxic waste would exceed the Table $302.4 \mathrm{RQS}$

(EPA 1985a). [See FEMP determination (WHC 1991d).]

\subsection{AIRBORNE EMISSIONS}

Potential airborne emission streams have been identified. These streams contain both radioactive and nonradioactive components.

\subsubsection{The 296-S-21 Stack}

The 296-S-21 Stack is the main exhaust stack for 222-S. This stream consists of exhaust air from 222-S laboratory hoods, exhaust air from hotcells, room exhaust, and process vacuum pump exhaust (Figure 4-2). The stream 
WHC-EP-0480-1

Figure 4-2. Airflow and Filtration Schematic for 222-S Laboratory.

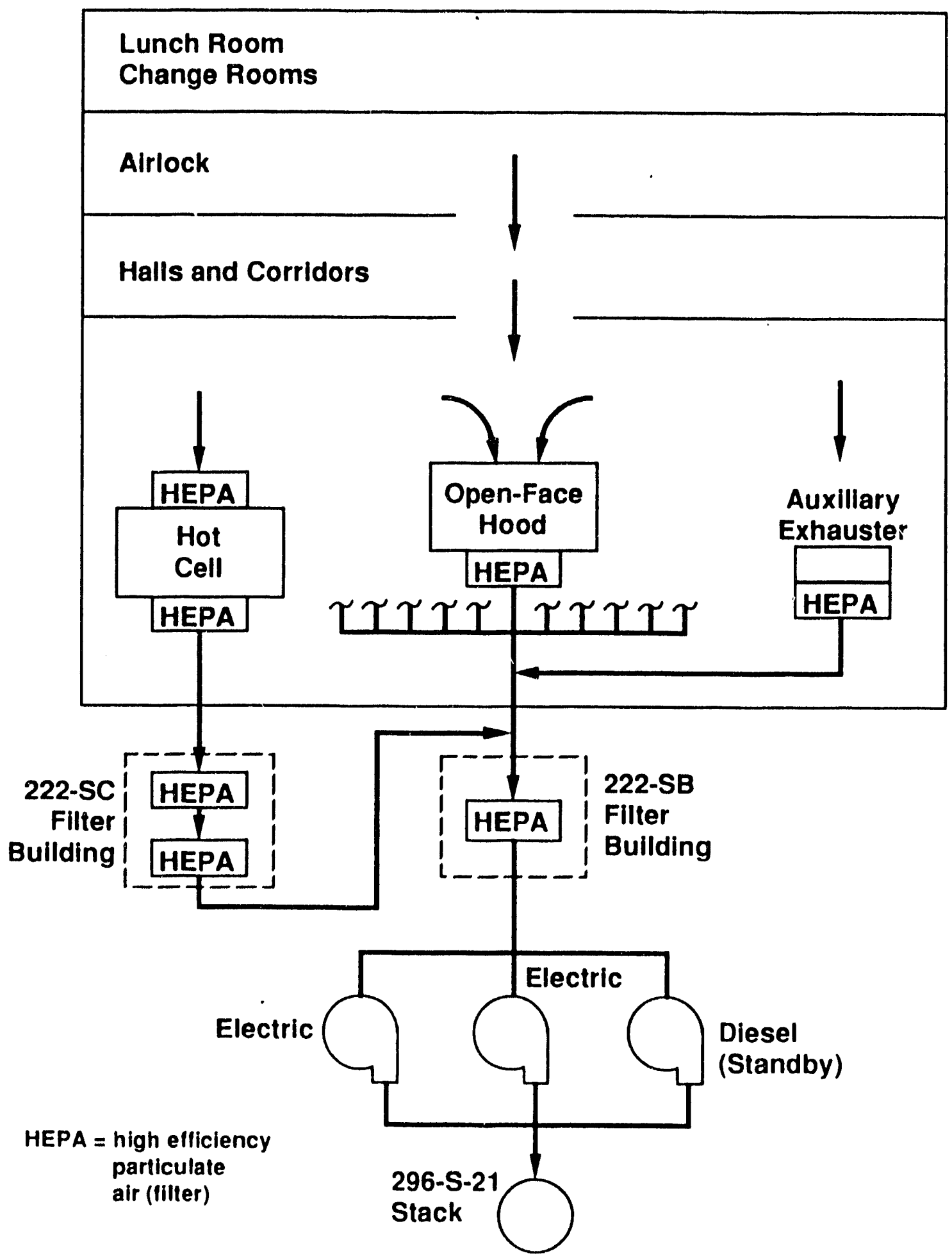


WHC-EP-0480-1

contains small amounts of radioactivity and is filtered through HEPA filters. There is also the potential for the stream to contain small amounts of nitrogen oxides from nitric acid fumes and small amounts of volatiles from lab chemicals. The stream is continuously monitored for alpha and beta radioactivity and is routinely sampled for quarterly analys is of gross alpha, gross beta, and specific nuclide analysis. No sampling for hazardous chemicals is performed.

The discharged exhaust gases are continuously sampled and periodically analyzed. Emissions for Calendar Year (CY) 1989 were reported as $<3.33 \times 10^{-6} \mathrm{Ci}$ for gross alpha and $1.78 \times 10^{-5} \mathrm{Cj}$ for gross beta; see Table B-2 (Brown et al. 1990). Application of the multiplicative factor of 3,000 to simulate loss of HEPA filtration gives an estimated release of $0.010 \mathrm{Ci}$ for gross alpha and $0.053 \mathrm{Ci}$ for gross beta. Based on the estimated inventory (Section 2.3.2), it is assumed that all gross alpha is ${ }^{239} \mathrm{Pu}$ and all gross beta is ${ }^{90} \mathrm{Sr}$. Using the Unit Dose Calculations for Westinghouse Hanford Facility Effluent Monitoring Plans (Rhoads 1990), the CAP-88 (Beres 1990) dose estimates for the maximum offsite individual are:

$$
\begin{array}{ll}
{ }^{239} \mathrm{Pu} & 0.0515 \mathrm{mrem} / \mathrm{yr} \text { EDE } \\
{ }^{90} \mathrm{Sr} & 0.0014 \mathrm{mrem} / \mathrm{yr} \text { EDE }
\end{array}
$$

Using an alternative (more conservative) assumption that ${ }^{241} \mathrm{Am}$ accounts for all the gross alpha measurement, the calculated dose is increased to 0.078 mrem EDE. The total estimated dose $\left({ }^{239} \mathrm{Pu},{ }^{90} \mathrm{Sr}\right)$ to the maximally exposed offsite individual is $0.05 \mathrm{mrem}$ EDE (assumed $10-\mathrm{m}$ stack). A FEMP is not required due to emission of radionuclides [see FEMP determination (WHC 1991d)] because 0.1 mrem EDE is not exceeded. The WHC-CM-7-5, Part D (WHC 1991b) requires sampling of airborne effluents that have the potential to exceed $10 \%$ of any DCG-public value on an annual average. Environmental monitoring data show measured average gross alpha emissions as "less than" about $18 \%$ of the DCG-public values (for ${ }^{241} \mathrm{Am}$ and ${ }^{239} \mathrm{Pu}$ ), and thus it is reasonable to assume that the stack has the potential to exceed $10 \%$ of the ${ }^{239} \mathrm{Pu}$ or ${ }^{249} \mathrm{Am} D C G-p u b l i c$ value. Therefore, a continuation of the present sampling schedule is recommended.

Toluene and xylene are routinely used in relatively large quantities. Although other volatile materials exist in the lab, they are generally used in small quantities and the containers are kept stoppered while not in use; thus, evaporation is minimal. Although there are large numbers of volatile chemicals available in the lab, they are in varying quantities and concentrations in several different locations. The only possible way all of the inventory could be evaporated in a short time would be because of a catastrophic event such as an earthquake. This is considered outside the scope of this document. Other nonvolatile materials have very little or no chance of entering the gaseous effluent stream either through entrainment or evaporation.

Potential releases during upset conditions were evaluated, based on the current 222-S chemical inventory of volatile chemicals and the criteria in Section 4.0. No chemicals that would exceed the final RQs of Table 302.4 (EPA 1985a) were found. Therefore, a FEMP is not required due to chemical emissions. [See FEMP determination (WHC 1991d).] 


\subsubsection{The 296-S-16 Stack}

The stream from the 296-S-16 Stack consists of exhaust air from the 296-S tanks. The exhaust air from the tanks goes through a de-entrainer tank and HEPA filters before discharge to the atmosphere. The stick exhausts the gases from tanks TK-101, TK-102, and TK-103. The exhaust ga,es discharged are continuously sampled and the CY 1989 emissions were reported as $<6.59 \times 10^{-9} \mathrm{Ci}$ for gross alpha and $3.32 \times 10^{-8} \mathrm{Ci}$ for gross beta (See Table B-2 in Brown et al. 1990). For those values, a multiplication factor of 3,000 is assumed to simulate loss of HEPA filtration; therefore, the uncontrolled releases would be estimated at $<1.98 \times 10^{-5} \mathrm{Ci}$ for gross alpha and $9.96 \times 10^{-5} \mathrm{Ci}$ for gross beta.

Assuming ${ }^{239} \mathrm{Pu}$ as the alpha material, ${ }^{90} \mathrm{Sr}$ for the beta material, and using Rhoads 1990, the maximum offsite dose to an individual from the release of this level of material is $7.2 \times 10^{-5}$ mrem EDE for ${ }^{239} \mathrm{Pu}$ and $2 \times 10^{-6} \mathrm{mrem}$ EDE for ${ }^{90} \mathrm{Sr}$ (ground-level release). The total maximum offsite exposure is estimated to be $7.4 \times 10^{-5}$ mrem EDE. Similar calculations using the CAP-88 (Beres 1990) dose estimates gave a total maximum offsite exposure of $1.0 \times 10^{-4} \mathrm{mrem} E D E$. The EDE for ${ }^{24} \mathrm{Am}$ was also calculated assuming the gross alpha measurements derived $100 \%$ from ${ }^{24} \mathrm{Am}$. The dose calculated was $1.1 \times 10^{-4}$ mrem EDE, which is still significantly below the $0.1 \mathrm{mrem} 1 \mathrm{imit}$ [FEMP determination (WHC 1991d)]. Therefore, a FEMP is not required for the emissions of radionuclides; however, WHC-CM-7-5, Part D (WHC 1991b) requires sampling for airborne effluents that have the potential to exceed $10 \%$ of the public DCG values on an annual average. The 1989 data for 296-S-16 show measured average gross alpha emissions as "less than" about $18 \%$ of the DCG-public values (for ${ }^{241} \mathrm{Am}$ and ${ }^{239} \mathrm{Pu}$ ), and thus it is reasonable to assume that the stack has the potential to exceed $10 \%$ of the ${ }^{239} \mathrm{Pu}$ or ${ }^{241} \mathrm{Am} \mathrm{DCG-public}$ value.

This stream is regulated because it contains radionuclides. Based on information reviewed and observations during the assessment, the stream does not appear to contain regulated amounts of other constituents during routine operations. In considering upset conditions, the same inventory would be used as for the 296-S-21 Stack. No chemical in excess of RQs was found to be emitted under routine or upset conditions. Therefore, a FEMP is not required because of the emission of hazardous chemicals. [See FEMP determination (WHC 1991d).]

\subsubsection{The 296-S-23 Stack}

This stack exhausts the sample gallery hood in 219-S. Air is drawn through the sample gallery into the hood and exhausted to the stack. No hazardous chemicals or radioactive materials are present in the sample gallery room. The only source of hazardous or radioactive materials would be from the sample box in the 219-S vault. The sample box contains sampled liquid drawn from the tanks. The air being exhausted from the sample box will be essentially the same as what is being exhausted through the 296-S-16 tank exhauster. The only difference between the two streams is that the 296-S-16 stream has a demister before discharging through a HEPA filter, while there is no demister in the 296-S-23 exhaust system. The tanks contain the radioactive chemical wastes from the 222-S Laboratory. The air from the 
sample gallery hood has a very low potential for contamination with radionuclides or hazardous chemicals. Because of the low potential for contamination, the stack is not currently monitored or sampled. This stream, however, does pass through a HEPA filter before discharge to the atmosphere. This stack operates on an as-needed bassis (10-12 h/mo). The flowrate of the stack, when operating, is about $720 \mathrm{ft}^{3} / \mathrm{min}$.

The hood is operated infrequently, about $10-12 \mathrm{~h} / \mathrm{mo}$. The potential effluents are (1) the airborne material in the 219-S tank and vault, and (2) air drawn from the sample gallery. The most conservative estimate of a potential discharge would be at the same activity level as estimated for the 296-S-16 Stack (Section 4.2.2). The flow rate for the 296-S-23 discharge is 5.5 times greater than for $296-\mathrm{S}-16\left(720 \mathrm{ft}^{3} / \mathrm{min}\right.$ vs. $\left.130 \mathrm{ft}^{3} / \mathrm{min}\right)$, but the duration is 60 times less $(720 \mathrm{~h}$ vs. $12 \mathrm{~h})$. The total volume of gas discharged is $0.0917(5.5 / 60)$ of the volume from the 296-S-16 Stack, as would be the calculated offsite dose. Therefore, the estimated offsite dose [GENII, (Napier et a1. 1988) ground-level releasel to the maximum individual is $6.6 \times 10^{-6} \mathrm{mrem}$ EDE for ${ }^{239} \mathrm{Pu}$ and $1.8 \times 10^{-7}$ mrem EDE for ${ }^{90} \mathrm{Sr}$. Thus, the total dose to the maximally exposed offsite individual is $6.8 \times 10^{-6} \mathrm{mrem}$ EDE. A similar calculation using the CAP-88 dose estimates gave a maximum offsite exposure of $9.5 \times 10^{-6} \mathrm{mrem} E D E$. Therefore, a FEMP is not required due to the estimated radionuclide emissions. [See FEMP determination (WHC 1991d).]

This waste stream is regulated because it contains radionuclides. The stream does not contain regulated amounts of other constituents. Considering potential chemical releases due to upset conditions, the same inventory would be used (as discussed above) for the 296-S-21 Stack. Due to the decreased use, no chemicals could exceed RQs. A FEMP is not required due to estimated chemical releases. [See FEMP determination (WHC 1991d).]

\subsubsection{The Vacuum Air Sample Pumps Stack}

Exhaust air from the 222-S vacuum air sample (VAS) pumps was vented directly to the environment in the past. This stream has been rerouted into the 222-S main exhaust plenum and is exhausted via the 296-S-21 Stack. Thus, the contribution from this release point is included in the discussion of 296-S-21, Section 4.2.1.

\subsubsection{The 222-SA Stack}

The 222-SA Stack receives exhaust air from the laboratory hoods located in the 222-SA Building. There is the potential for this stream to contain trace amounts of volatile organics from chemicals handled in the hoods. Because 222-SA does not handle radioactive materials, there is no potential for this stream to contain radionuclides. Based on the lack of potential for radionuclide or hazardous chemical emissions, the stream has not been sampled for either chemicals or radionuclides, and no treatment of the stream occurs before discharge to the atmosphere. 
Based on the presence of administrative procedures prohibiting disposal of any hazardous chemical in the hoods and an assessment of the total inventory, there was no discernible mechanism by which routine emissions of volatile hazardous chemicals could occur.

An evaluation of potential releases of volatile chemicals under the upset conditions discussed in Section 4.2.1 indicates no chemicals in the laboratory inventory could be emitted in excess of EPA Table 302.4 RQs (EPA 1985a). Therefore, a FEMP is not required for airborne chemical emissions. [See FEMP determination (WHC 1991d).]

\subsubsection{The Nitric Acid Tank Vent}

This stream derives from the $222-S$ nitric acid storage tank (600 gal working capacity) and vents directly to the atmosphere. The tank does not contain radioactive materials, so there is no potential for the stream to contain radionuclides. There is no treatment before discharge of the stream to the atmosphere. Based on consideration of $\mathrm{NO}_{x}$ discharge limits of 40 CFR 302, Table 302.4 (EPA 1985a), there does not appear to be a credible scenario where an RQ could be exceeded.

This stream is classified as nonregulated, based on process knowledge, because it does not contain regulated amounts of nitrogen oxides. There is no need for a FEMP due to airborne chemical emissions.

\subsection{SUMMARY}

Based on the data and applicable regulations reviewed, a FEMP is required for three liquid streams. A summary of facilities considered, and the results of the FEMP determination process, is presented in Table 4-1. 
WHC-EP-0480-1

Table 4-1. Facility Effluent Monitoring Plan Determination Summary.

\begin{tabular}{|c|c|c|c|c|}
\hline Faciiity & Matrix & $\begin{array}{c}\text { Disiharge } \\
\text { joint }\end{array}$ & $\begin{array}{l}\text { FEMP } \\
\text { required? }\end{array}$ & Reason for FEMP \\
\hline $\begin{array}{l}\text { 222-S Laboratory } \\
\text { Wastewater/207-SL } \\
\text { Retention Basins }\end{array}$ & Liquid & 216-S-26 Crib & Yes & $\begin{array}{l}\text { Potential } \\
\text { hazardous } \\
\text { chemical and/or } \\
\text { radioactive } \\
\text { compound release } \\
\text { under upset } \\
\text { conditions }\end{array}$ \\
\hline $\begin{array}{l}\text { 222-SA Laboratory } \\
\text { Wastewater }\end{array}$ & Liquid & 216-S-26 Crib & Yes & $\begin{array}{l}\text { Potential } \\
\text { hazardous } \\
\text { chemical release } \\
\text { under upset } \\
\text { conditions }\end{array}$ \\
\hline $\begin{array}{l}291-S \text { Stack Fan } \\
\text { House Cooling } \\
\text { Water }\end{array}$ & Liquid & $216-S-26 \mathrm{Crib}$ & No & \\
\hline $\begin{array}{l}222-S \text { Nitric Acid } \\
\text { Storage Tank }\end{array}$ & Liquid & $\begin{array}{l}\text { Nitric Acio } \\
\text { Tank }\end{array}$ & No & \\
\hline $\begin{array}{l}219-5 \text { Building } \\
\text { Liquid Caustic } \\
\text { Tank }\end{array}$ & Liquid & $\begin{array}{l}\text { Caustic Tank } \\
\text { Valve }\end{array}$ & No & \\
\hline $\begin{array}{l}\text { 219-S Waste } \\
\text { Handling Facility }\end{array}$ & Liquid & $\begin{array}{l}219-5 \text { TK-102 } \\
\text { Outlet jumper }\end{array}$ & Yes & $\begin{array}{l}\text { Potential } \\
\text { hazardous } \\
\text { chemical and/or } \\
\text { radioactive } \\
\text { compound release } \\
\text { under upset } \\
\text { conditions }\end{array}$ \\
\hline $\begin{array}{l}222-S \text { Nitric Acid } \\
\text { Storage Tank }\end{array}$ & Air & Tank Vent & No & \\
\hline 222-S Laboratory & Air & $\begin{array}{l}296-S-21 \\
\text { Stack }\end{array}$ & No & \\
\hline 219-S Tanks & Air & $\begin{array}{l}296-S-16 \\
\text { Stack }\end{array}$ & No & \\
\hline $\begin{array}{l}219-S \text { Sample } \\
\text { Gallery }\end{array}$ & Air & $\begin{array}{l}296-5-23 \\
\text { Stack }\end{array}$ & No & \\
\hline 222-SA Laboratory & Air & 222-SA Stack & No & \\
\hline
\end{tabular}

FEMP = Facility Effluent Monitoring Plan 
WHC-EP-0480-1

This page intentionally left blank. 
WHC-EP-0480-1

\subsection{EFFLUENT POINT OF DISCHARGE DESCRIPTION}

A brief description of each potential point of discharge was included in Sections 2.3 and 4.0 and will not be repeated here for effluent streams that are not required to have a FEMP. Additional details are provided below for the contributors that discharge to the 216-S-26 Crib (McNamar and Fuller 1986) and the waste-transfer jumper out of 219-S.

\subsection{GENERAL SYSTEM DESCRIPTION}

The 222-S Laboratory Complex wastewater system handles water flushes, steam condensate, cooling water, and other liquid streams that do not routinely contain significant radioactive contaminants or hazardous chemical wastes.

Effluents from $222-S$ and some from $219-5$ are routed to the 207-SL Retention Basins. The effluent from 207-SL is sampled at the 207-SL inlet or by grab sample and verified to be within release limits before transfer to the 216-S-26 Crib. Steam condensate from the 291-S Stack Fan House flows into the 207-SL Retention Basins Discharge Box and bypasses the Retention Basin itself. Effluents from the 222-SA standards laboratories discharge directly to the 8-in. vitrified clay pipe (VCP) going to the 216-S-26 Crib from the 207-SL Retention Basins. Neither stream is currently sampled.

The wastewater system main consists of a concrete-encased 8 -in. VCP that extends south of the 207-SL Retention Basins and underneath the 222-SA Building to manhole No. 3 (Figure 5-1). The $8-i n$. VCP then runs about $30 \mathrm{ft}$ east to the 216-S-26 Crib. Formerly, manhole No. 3 connected to an 8-in. VCP that ran south to the 216-S-19 Pond. The 216-S-19 Pond was removed from service in the summer of 1984 and the connecting 8 -in. VCP was plugged at manhole No. 3. The $216-\mathrm{S}-26$ inlet is approximately $640 \mathrm{ft}$ south and $170 \mathrm{ft}$ east of the 222-S Building and is located outside the 200 West exclusion area fence. The effluents are dispersed throughout the crib by 6 -in. perforated VCP. Disposal of effluents is by absorption into the soil. The flow consists of an estimated 1,000 gal/d from the 222-SA Building and approximately 7,000-15,000 gal/d from the 207-SL Retention Basins.

\subsection{THE 207-SL RETENTION BASINS}

The 207-SL Retention Basins acts as a temporary holding facility for potentially low-level radioactive and hazardous liquid effluents for the 222-S Laboratory Complex before discharge to the 216-S-26 Crib. Effluents from the 222-S and 219-S facilities are transferred to the 207-SL Retention Basins via a 4-in. fiberglass-reinforced pipe (FRP) enclosed in a

concrete-encased 8-in. VCP. The 4-in. FRP is fed by another 4-in. FRP enclosed in a concrete-encased 6-in. VCP from manhole No. 4 (219-S Facility), a 4-in. stainless-steel retention waste line and a 4-in. carbon-steel coolant and condensate drain at manhole No. 5 (222-S Multicurie Section), and a 3-in. stainless-steel retention waste line and $3-i n$. carbon-steel condensate drain at manhole No. 6 (222-S Analytical Section). Effluent to the basin is 
Figure 5-1. 222-S Laboratory Complex Wastewater System and French Drains.

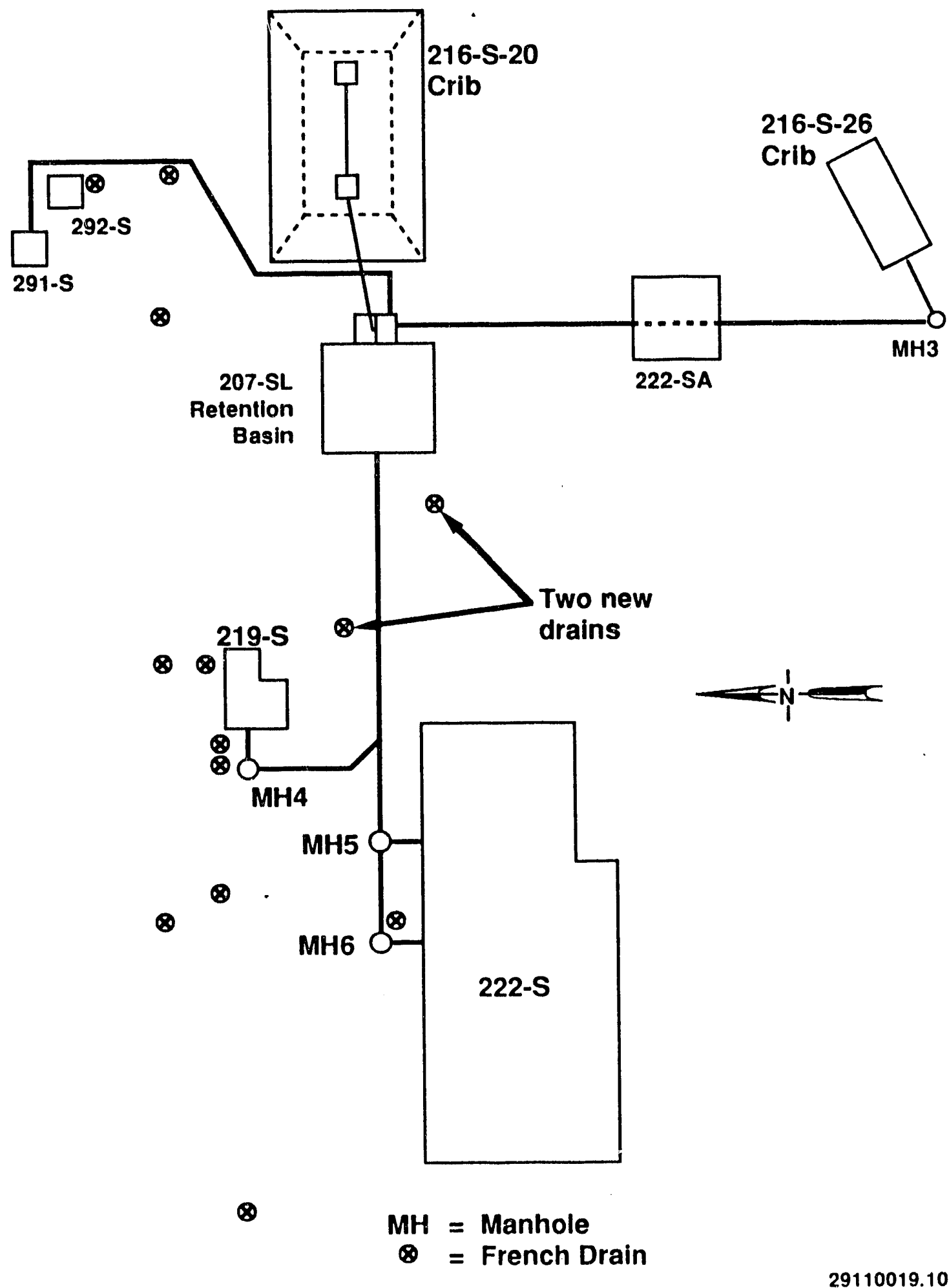


sampled and verified to be within CERCLA and RCRA pH release limits before being transferred to the 216-S-26 Crib by an 8-in. VCP. Steam condensate from the 291-S Stack Fan House is routed to the 207-SL discharge box via a 2-in. galvanized-steel pipe. Since this is discharged directly to the 207-SL discharge box, it bypasses the sampling unit at the 207-SL inlet and therefore is not sampled and analyzed before going to the 216-S-26 Crib. Located directly east of 207-SL is the 216-S-20 Crib. The 216-S-20 Crib has been permanently removed from service, but there is an existing line running to 216-S-20 from 207-SL. This crib was formerly used for disposal of low-level radioactive waste. The line to the $216-5-20 \mathrm{Crib}$ is valved, closed, and locked.

\subsection{2-SA STANDARDS LABORATORY}

Nonhazardous effluents from the laboratory sinks, fume hoods, glass washer, and vacuum pump cooling systems are discharged to a 2-in. polyvinyl chloride pipe drain. This 2-in. Tine then discharges directly into the 8-in. VCP going to the 216-S-26 Crib from the 207-SL Retention Basins. This 8-in. VCP Tine runs underneath the 222-SA Building and is not currently sampled or monitored.

\subsection{THE 219-S WASTE HANDLING FACILITY}

Cooling water from tanks TK-101, TK-102, and TK-103 c001ing water jackets, operating gallery sump No. 8 , and steam condensate from the operating gallery all empty into a 4-in. stainless-steel utility drain. Steam condensate from cell $A$ and $B$ steam heaters goes to a 2-in. stainless-steel condensate drain. Both the 2-in. and 4-in. lines run west out of the 219-S Building to manhole No. 4 where they connect to a 4-in. FRP. This 4-in. FRP runs inside a 6 -in. concrete-encased VCP to the 4-in. FRP that is inside an 8-in. concrete-encased VCP. This line, in turn, empties into the 207-SL Retention Basins.

\subsection{2-S WASTEWATER DRAIN SYSTEM DESCRIPTION}

The 222-S Building is divided into two sections; the Analytical Section, where low-level radiation lab work is done, and the Multicurie Section, where the higher level radiation work is accomplished. The Analytical Section occupies the western side of the building and the Multicurie Section occupies the eastern end. The Analytical-Section effluents go to two 4-in. drain lines in the basement tunnels and the Multicurie-Section effluents go to two $3-i n$. drain lines in the basement tunnels.

\subsubsection{Basement Tunnels}

Nonradioactive and nonhazardous effluents from the 222-S Laboratory are discharged to the 207-SL Retention Basins in four different 1ines: a 4-in. stainless-steel retention-basin waste line and 4-in. carbon-steel coolant and 
condensate line (Figure 4-1) for the Analytical Section, and a 3 -in. stainless-steel retention-bas in waste line and 3 -in. carbon-steel steam-condensate drain for the Multicurie Section. Sumps 1 through 6 discharge into the Analytical-Section 4-in. retention-basin waste line. Sump No. 5 is, in turn, fed by overflow and drain lines from vacuum pump No. 4 and a floor drain in a stairwell outside 222-S near door No. 19 on the north side of the building. All sumps act as floor drains for the tunnels. Vacuum pumps 1, 2, and 3 discharge into the Analytical-Section 4-in. coolant and condensate line. The Analytical-Section retention-basin waste and coolant and condensate lines then run north out to manhole No. 6 where they flow into the 4-in. FRP going to the 207-SL Retention Basins.

A floor drain outside door No. 18 goes to sump 7, which, in turn, discharges to the Multicurie-Section 3-in. stainless-steel retention basin waste 1 ine. The two sumps in tunnels $T-7$ and $T-8$ normally are pumped to the 219-S Waste Handling Facility. However, a 3-way valve on the sump discharge allows for transfer to the 3-in. retention-bas in waste line. (This would happen only in the event of an emergency.) Steam condensate from the 222-S Building main steam line flows into the $3-i n$. Multicurie-Section condensate line. The two 3 -in. lines then exit the north side of the building to manhole No. 6. At manhole No. 6, the lines connect into the 4-in. FRP going to the 207-SL Retention Basins.

\subsubsection{First Floor Analytical Section}

All Analytical-Section lab sinks and hood drains (except in rooms $2 B$ and $2 \mathrm{~B}-2$ ) go to the retention-bas in waste line. The lab sink and hood drain in 2B-2 and all drains in $2 \mathrm{~B}$ go to the 219-S Waste Handling Facility. All Analytical-Section water fountains; service sinks in rooms $7 B, 7 C$, and $7 D$; and bathroom sinks and floor drains in rooms $2 F$ and $2 G$ go to the AnalyticalSection retention-basin waste 1 ine.

\subsubsection{Second Floor Equipment Room}

The sink and glass saw drains in the glass-blowing shop go to the Analytical-Section retention-basin wastewater line. The distilled-water overflow and drain lines, second-floor steam condensate, fire-suppression sprinkler-system drain, hot-water generator-tank No. 20 overflow and drain, backflush and drain from Millipore deionized-water unit, a floor drain near the Millipore unit, and the flash tank overflow and drain lines all go to the Analytical-Section coolant and condensate line. Lines discharging into the flash tank include cooling water from the supply fan air washers, condensate from booster coils BC 1 through 6, and condensate from the reheat and preheat coils on supply fans 1 through 4 . Overflow and drain lines from the nitric acid supply tank are routed to the nitric acid storage tank outside of the building. The floor drain in room SIA (where the nitric acid supply tank is located) drains to the Multicurie-Section retention-basin waste line. 


\subsection{FRENCH DRAINS}

Several French drains for steam condensate serve the 222-S Laboratory Complex area. These drains serve as condensate drains for the main steam supply lines at S-Plant. The French drains discharge directly into the ground instead of the 207-SL Retention Basins. Only steam condensate from steam lines that have not entered any radioactive zones (i.e., inside 222-S) is allowed to be discharged to these drains and as such is not considered to have a potential for contamination. Each location of these drains is indicated in Figure $5-1$ by an " $x$ " in a circle.

\subsection{THE 219-S WASTE HANDLING FACILITY OUTLET VALVE (JUMPER)}

The jumper used for pumping waste from 219-S to a tank trailer truck for transport is located on the southeast corner of the 219-S Facility. The jumper consists of a 4-in. stainless-steel pipe rising approximately $3 \mathrm{ft}$ from the top of the 219-S tank vault cover. The pipe then takes a 90 degree bend and terminates in a flow meter. The flow meter has connectors attached to which a portable pump can be connected when pumping waste to a tank trailer truck. 
WHC-EP-0480-1

This page intentionally left blank.

5-6 


\subsection{EFFLUENT MONITORING/SAMPLING SYSTEM DESIGN CRITERIA}

This chapter discusses the contractor design criteria for effluent monitoring and sampling. Items discussed include (1) criteria for monitoring and sampling equipment, and (2) the criteria and bases for establishing sampling intervals of effluent streams.

\subsection{CURRENT DESIGN CRITERIA}

The only effluent streams for which a FEMP is required are the 207-SL and 222-SA discharges to the $216-5-26 \mathrm{Crib}$. The lines running to the

207-SL Retention Basins from the 222-S Laboratory and the 219-S Waste Handling Facility are 4-in. FRP-enclosed in a concrete-encased 6-in. VCP. Effluent to the basin is routed to a time and/or proportional sampling device that is currently set up to take a $150-\mathrm{ml}$ sample for every $150 \mathrm{gal}$ of flow. The liquid sampler collects the sample portion in a refrigerated compartment that maintains a temperature of approximately $4^{\circ} \mathrm{C}$. The sample is extracted from the effluent stream via a vacuum-sampling method. Design criteria for the system are available at the 2704-S Building in contractor-vendor information, file 20914. In addition, there is a project (WHC 199le) to add additional storage capacity in the form of three tanks of 12,000 gal each. It is stated in the above-referenced document that the tanks will be designed to allow the taking of representative samples of the wastewater in the tank; however, no details are given. This project also will allow 222-SA and 291-S effluent lines to be rerouted to the 207-SL Retention Basins for sampling before discharge.

The time interval of sampling is based on a batch mode where the frequency of sampling is dictated by the concept that each batch of effluent will be sampled before it is released to the crib.

There do not appear to be any specific design criteria yet developed for the current grab-sampling of the basin. There are also no criteria for the accuracy of the manual volume measurements on the basins.

\subsection{SUGGESTED DESIGN CRITERIA}

The sampling of the 207-SL Retention Basins wastewater is performed to ensure compliance with DOE Orders 5400.1 (DOE 1988a) and 5400.5 (DOE 1990a), State implementation of RCRA, and the Land Ban regulations of WAC 173-303 (Ecology 1991a) and 40 CFR 268 (EPA 1987c). The criteria listed below are based on the need in all of these regulations to obtain a representative 
sample of the waste. The guidance on sampling given in SW 846, Volume II, Chapters 9, 10, and 11 (EPA 1986a) provides an acceptable set of criteria for liquid effluent sampling. The design criteria for obtaining a representative: liquid sample should consider the following factors.

1. Liquid effluent stream sampling should be performed in such a manner that volatile organic constituents are not lost. Generally this requires that the sample be extracted from the stream using positive displacement pumps (e.g., piston pump) or methods of intermittent flow diversion. Suction pumps (e.g., centrifugal and peristaltic) are not advisable due to induced outgassing of volatiles.

2. Basins or tanks should be grab-sampled in such a way as to account for possible vertical stratification and horizontal gradients emanating from the basin influent point. [Guidance in this area is discussed in SW 846 (EPA 1986a), Vol. II, Chapter 9.] With regard to the vertical stratification in the current basins, this guidance would require the use of a weighted bottle-type sampler and several samples taken at different depths. These could be composited and a subsample taken to the laboratory.

In order to minimize the effects of horizontal gradients on the representativeness of the sample, the current basins would need to have a distribution of sampling ports installed in the surface cover.

3. Liquid effluent stream sampling systems should be given careful consideration as to the variability in flowrate and waste constituents with time. Those streams that vary significantly over time with flow and/or waste constituent concentration may not be suitable for time or flow-proportional sampling.

4. Volume measurements of the basin or of the volume flowing into the basin via an inline flow recorder should be assessed for accuracy and precision and undergo some type of periodic calibration.

5. The construction materials of sampling lines, receiving containers, and grab-sampling equipment should be compatible with the intended range of analytes. Guidance on suitable materials may be found in Chapter 11 of SW 846 (EPA 1986a). The information pertinent to 222-S has been summarized in Table 6-1. 
WHC-EP-0480-1

Table 6-1. Sampling Criteria and Materials Suitable for Samplers and Sample Containers.

\begin{tabular}{|c|c|c|c|c|}
\hline Constituent & $\begin{array}{l}\text { Recommended } \\
\text { container }\end{array}$ & Preservative & $\begin{array}{l}\text { Maximum } \\
\text { holding } \\
\text { time }\end{array}$ & $\begin{array}{l}\text { Minimum } \\
\text { volume } \\
\text { for } \\
\text { analys is }\end{array}$ \\
\hline $\begin{array}{l}\text { Radionuclides } \\
\text { gross alpha } \\
\text { gross beta } \\
{ }_{241} \mathrm{Am} \\
{ }^{239 / 240} \mathrm{Pu} \\
{ }^{137} \mathrm{Cs} \\
{ }^{90} \mathrm{Sr}\end{array}$ & $P, G, T$ & $\begin{array}{c}\text { Acidify to } \\
\mathrm{pH}<2\end{array}$ & $6 \mathrm{mo}$ & $1 \mathrm{gal}$ \\
\hline Total organic carbon & $\mathrm{T}, \mathrm{G}$ & 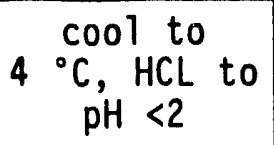 & $28 d$ & $4 \times 15 \mathrm{~mL}$ \\
\hline $\mathrm{pH}$ & $T, P, G$ & none & $\begin{array}{c}\text { Analyze } \\
\text { immediately }\end{array}$ & $25 \mathrm{~mL}$ \\
\hline Nitrate & $T, P, G$ & $\begin{array}{c}4{ }^{\circ} \mathrm{C}, \mathrm{H}_{2} \mathrm{SO}_{4} \\
\text { to } \mathrm{pH}<2 \\
\text { none }\end{array}$ & $\begin{array}{l}14 \mathrm{~d} \\
48 \mathrm{~h}\end{array}$ & $25 \mathrm{~mL}$ \\
\hline $\begin{array}{l}\text { Metals } \\
\text { Cadmium } \\
\text { Chromium (total) } \\
\text { Lead } \\
\text { Mercury } \\
\text { Silver }\end{array}$ & $\begin{array}{l}T, P \\
T, P \\
T, \\
T, \\
T, \\
T\end{array}$ & $\begin{array}{c}\text { adjust pH }<2 \\
\text { WHNO }_{3}\end{array}$ & $\begin{array}{l}6 \mathrm{mo} \\
6 \mathrm{mo} \\
6 \mathrm{mo} \\
28 \mathrm{~d} \\
6 \mathrm{mo}\end{array}$ & $100 \mathrm{~mL}$ \\
\hline $\begin{array}{l}\text { Volatile organic } \\
\text { compound } \\
\text { Carbon tetrachloride } \\
\text { Chloroform } \\
\text { Tetrachloroethylene } \\
\text { Trichloroethylene } \\
\text { Chlorobenzene } \\
\text { Pyridine }\end{array}$ & $T, G$ & $\begin{array}{l}{ }^{\mathrm{COO}}{ }^{\circ} \mathrm{C} \text { to } \mathrm{add} \\
0.008 \% \\
\mathrm{Na}_{2} \mathrm{~S}_{2} \mathrm{O}_{3}\end{array}$ & $14 d$ & $2 \times 40 \mathrm{~mL}$ \\
\hline
\end{tabular}

$P=$ polyethylene

$G=$ glass

$T=$ teflon 
WHC-EP-0480-1

This page intentionally left blank.

$6-4$ 


\subsection{CHARACTERIZATION OF CURRENT EFFLUENT MONITORING SYSTEM}

The 207-SL. Retention Basins effluent to the 216-S-26 Crib is currently batch sampled for gross alpha, gross beta, $\mathrm{pH}, \mathrm{TOC}$, and nitrate. The procedures used to obtain and to analyze samples are listed in Table 7-1. Each batch is sampled before it is released.

A flow-proportional sampler is used to obtain a representative sample of effluent from the 222-S Building waste stream before it enters the 207-SL basins. The sampler uses a vacuum-sampling line for pulling a 150-ml sampler for every 150 gallons of effluent. The sample is collected in a refrigerated compartment that maintains a temperature of approximately $4{ }^{\circ} \mathrm{C}$. The liquid level of the basins is checked once every shift ( 3 times a day). When the liquid level reaches 20 to 25 inches, the effluent is rerouted to the empty basin and the sample accumulated in the sampler is removed and transported to the 222-S Laboratory for analysis.

The sample is collected and per procedure L0-100-167 "SAMPLE AND TRANSFER 207-SL RETENTION BASIN LIQUID WASTE." The sample is drained from the collection container into two separate sample bottles. The sample bottles are labeled with:

- Serial number

- Date

- 207-SL (or 207-SL composite)

- Time

- Where released to (216-S-16 Crib)

- Radioactive sticker.

The sampling personnel record the date, shift, sample number, and flow integrator reading in gallons on the 207-SL Record Sheet. The lab leader then subtracts the last integrator reading from the current reading to determine the volume in the basin. If the flow integrator is not operable the sampling personnel determine the gallons of liquid in the basin by reading the liquid-level gauges on the east end of the basin and using the conversion table in 50-080-001 to convert liquid level to gallons. The sample is then delivered to the laboratory according to procedure L0-090-101.

The technical specifications for effluent release (Fuller 1988b) are for gross alpha, gross beta, pH, and chemical releases. Table 7-2 summarizes these requirements. There are currently no procedural specifications for evaluating the TOC or nitrate analyses to determine the suitability of releasing the contents of the 207-SL Retention Basins to the crib.

The 291-S Stack Fan House cooling water liquid effluent and the liquid effluent from 222-SA will be rerouted to enter the 207-SL Retention Basins complex during the construction of the new tanks. 
Table 7-1. Current Sampling/Monitoring Procedures.

\begin{tabular}{|c|c|c|}
\hline Activity & Procedure No. & Title \\
\hline Dip sample & SO-080-001 & $\begin{array}{l}\text { Sample and Transfer 207-SL Effluent } \\
\text { to } 216-S-26 \text { Crib }\end{array}$ \\
\hline $\begin{array}{l}\text { Compositing water } \\
\text { samples }\end{array}$ & LA-549-101 & Compositing \\
\hline Gross alpha analysis & LA-508-113 & $\begin{array}{l}\text { Low-Level Alpha and Beta in Water } \\
\text { Samples }\end{array}$ \\
\hline Gross beta analysis & $L A-508-113$ & $\begin{array}{l}\text { Low-Leve1 Alpha and Beta in Water } \\
\text { Samples }\end{array}$ \\
\hline TOC analysis & $L A-344-105$ & $\begin{array}{l}\text { Determination of Carbon in Solutions } \\
\text { by Combustion and Calculation }\end{array}$ \\
\hline pH Analysis & $L A-212-102$ & $\begin{array}{l}\text { Determination of } \mathrm{pH} \text { Direct } \\
\text { Measurement }\end{array}$ \\
\hline Nitrate analysis & LA-533-101 & Anion Analysis \\
\hline${ }^{241} \mathrm{Am}$ & $L A-943-123$ & $\begin{array}{l}\text { Separation of } \mathrm{Pu} \text { and } \mathrm{Am} \text { by Ion } \\
\text { Exchange }\end{array}$ \\
\hline $239,240 \mathrm{Pu}$ & LA-943-123 & $\begin{array}{l}\text { Separation of } \mathrm{Pu} \text { and } \mathrm{Am} \text { by Ion } \\
\text { Exchange }\end{array}$ \\
\hline${ }^{137} \mathrm{Cs}$ & LA-548-121 & $\begin{array}{l}\text { Preparation of Sample Mounts for Ge } \\
\text { (Li) Gamma Energy Analysis--Low-Level }\end{array}$ \\
\hline${ }^{90} \mathrm{Sr}$ & LA-220-104 & $\begin{array}{l}\text { Strontium- } 89 \text {, and/or Strontium } 89 \text { and } \\
90 \text { in Water by Carbonate } \\
\text { Precipitation }\end{array}$ \\
\hline Sample receiving & L0-090-101 & $\begin{array}{l}\text { Sample Receiving and Custodianship- } \\
222-S \text { Laboratory. }\end{array}$ \\
\hline
\end{tabular}

TOC = total organic carbon 
Table 7-2. Liquid Effluert Discharge Specifications.

\begin{tabular}{|c|c|c|c|}
\hline Analyte & $\begin{array}{c}\text { Classification } \\
\text { of event }\end{array}$ & $\begin{array}{c}\text { Specification } \\
\text { Limit }\end{array}$ & Action \\
\hline Gross alpha & $\begin{array}{l}\text { - Working } \\
\text { level } \\
\text { - Warning } \\
\text { level } \\
\text { - Action level }\end{array}$ & $\begin{array}{c}3 \times 10^{-8} \mu \mathrm{Ci} / \mathrm{ml} \\
6 \times 10^{-8} \mu \mathrm{Ci} / \mathrm{ml} \\
1.2 \times 10^{-1} \mu \mathrm{Ci} / \mathrm{ml}\end{array}$ & $\begin{array}{l}\text { Notify management/ } \\
\text { supervisor for action to } \\
\text { be taken. }\end{array}$ \\
\hline Gro:s beta & $\begin{array}{l}\text { - Working } \\
\text { level } \\
\text { - Warning } \\
\text { level } \\
\text { Plant } \\
\text { emergency }\end{array}$ & $\begin{array}{l}1 \times 10^{-6} \mu \mathrm{Ci} / \mathrm{ml} \\
2 \times 10^{-5} \mu \mathrm{Ci} / \mathrm{ml} \\
4 \times 10^{-5} \mu \mathrm{Ci} / \mathrm{ml}\end{array}$ & $\begin{array}{l}\text { Same as for gross alpha } \\
\text { above. }\end{array}$ \\
\hline $\mathrm{pH}$ & & $<2,>12.5$ & $\begin{array}{l}\text { Contact management, hold } \\
\text { effluent. }\end{array}$ \\
\hline Chemical & & Any known release & Contact management. \\
\hline
\end{tabular}

The following monitoring and sampling systems are currently in place at the 222-S Laboratory Complex. They do not require a monitoring plan for compliance with State or Federal regulations because emissions under routine and upset conditions are below FEMP requirements. However, the effluents du require monitoring according to Westinghouse Hanford policy.

- Stack 296-S-21 - 222-S Laboratory Ventilation. This stack exhausts filtered air from the 222-S Laboratory hoods, gloveboxes, hot-cells, and the room ventilation system. The sampling and monitoring system includes a record sampler, an alpha continuous air munitor (CAM) unit, and a beta-gamma CAM unit with sackup power and remote alarming capability.

- Stack 296-S-16 --219-S Tank Vault Ventilation. This stack exhausts filtered air from the 219-S Building vault and waste tanks. The sampling and monitoring system includes a record sampler and the monitor will sound a local alarm under conditions of low flow. 
WHC-EP-0480-1

This page intentionally left blank. 
WHC-EP-0480-1

\subsection{HISTORICAL MONITORING AND SAMPLING DATA FOR EFFLUENT STREAMS}

\subsection{NORMAL CONDITIONS}

Table 8-1 summarizes the radiological effluent data for 1987-1991. Preliminary 1991 data is also presented. In 1989, isotope-specific data for ${ }^{239 / 240} \mathrm{Pu}$ and ${ }^{249} \mathrm{Am}$ were added. For gross alpha, gross beta, and ${ }^{89 / 90} \mathrm{Sr}$, there does not appear to be any indication of a trend either up or down. The 1989 ${ }^{137} \mathrm{Cs}$ concentration and total activity are approximately a factor of 10 higher than 1987 and 1988. The effluent is al so analyzed for nitrate and TOC. At present, the nitrate levels measured in 1987-1990 (Table 8-2) are several orders of magnitude lower than the $1 \times 10^{5} \mathrm{mg} / \mathrm{L}$ that would cause the effluent to be regulated under WAC 173-303-084 (Ecology 1991a). The TOC 100-mg/L $1 \mathrm{imit}$ is used as a warning of potential releases and to protect the ion-exchange capacity of the soil column.

The mission of the laboratory is not expected to change significantly in future years; thus emissions in the liquid effluent are not expected to change significantly and current data together with consideration of available inventory should provide an adequate basis for effluent monitoring decisions.

\subsection{UPSET CONDITIONS}

Event Fact Sheets were evaluated for the time period 1989, 1990, and the first three months of 1991 . The only events considered relevant to the liquid streams were two incidents where the contents of the 207-SL Retention Basins were inadvertently released to the 216-5-26 Crib before being analyzed and one instance of finding mercury in a sink drain. In one basin-related case (ACSL-90-002, 1/12/90), the basin outlet valve was left partially open and in the other (ACSL-90-017, 4/25/90), the outlet valve appeared closed but apparently did not reseat completely. These two events indicate the need to have a liquid monitor in the effluent line to the $216-5-26$ Crib to alert plant personnel of accidental discharges from the basin. This is particularly important when the proportional sampler is not operable and a representative sample is not possible after the fact.

The accidental discovery of mercury in a sink drain (ACSL-90-029, $06 / 12 / 90)$ is illustrative of the inadvertent introduction of a hazardous material to the effluent stream and reinforces the need to monitor for potential effluent contaminants that may appear under upset conditions. 
WHC-EP-0480-1

Table 8-1. Historical Concentration and Total Discharge of Radioactivity in 222-S Wastewater Effluent Concentration $(\mu \mathrm{Ci} / \mathrm{mL})$ and Total ( $\mathrm{C}$ i) Radionuclides Released.

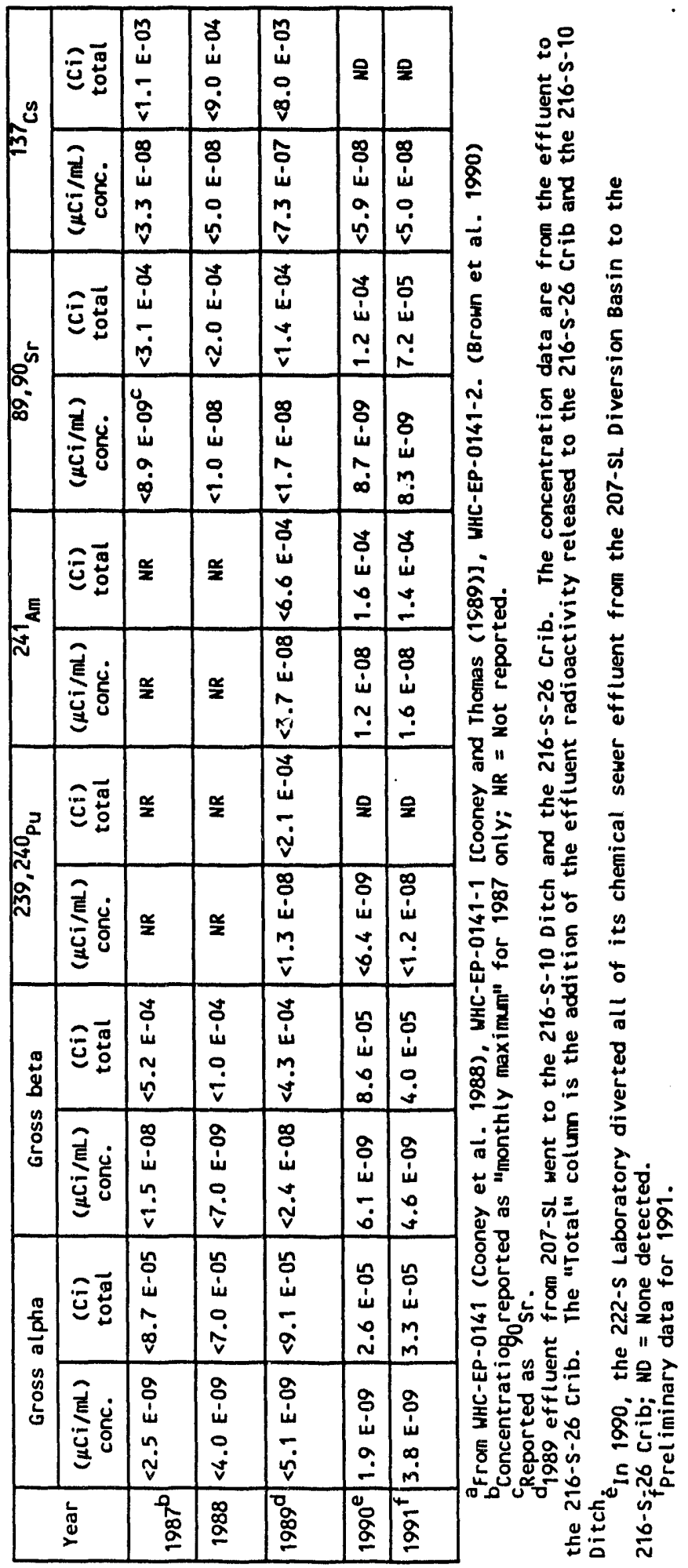


Table 8-2. Historical Nitrate $\left(\mathrm{NO}_{3}^{-}\right.$) and Total Organic Carbon in 222-S Wastewater. ${ }^{a}$

\begin{tabular}{|c|c|c|c|c|}
\hline \multirow[b]{2}{*}{ Year } & \multicolumn{2}{|c|}{ Nitrate ${ }^{b}$} & \multicolumn{2}{|c|}{ Total organic carbon } \\
\hline & $\begin{array}{c}\text { Annual } \\
\text { average } \\
\text { (mg/L) }\end{array}$ & $\begin{array}{c}\text { Aninual mass } \\
(\mathrm{kg})\end{array}$ & $\begin{array}{c}\text { Monthly maximum } \\
(\mathrm{mg} / \mathrm{L})\end{array}$ & $\begin{array}{c}\text { Annual } \\
\text { mass } \\
(\mathrm{kg})\end{array}$ \\
\hline 1987 & 5 & 184 & 12 & 91 \\
\hline 1988 & 7 & 190 & 4 & 87 \\
\hline 1989 & 32 & 426 & 8 & 49 \\
\hline 1990 & 5 & 65 & 118 & 250 \\
\hline 1991 & 5 & 45 & 16 & 63 \\
\hline
\end{tabular}

${ }^{\text {a}}$ From WHC-EP-0141 (Coony et a1. 1988), WHC-EP-0141-1

(Coony and Thomas 1989), WHC-EP-0141-2 (Brown et al. 1990).

${ }^{5}$ Regulatory limit is $1.0 \mathrm{E}+05 \mathrm{mg} / \mathrm{L}$ per WAC 173-303-084 for a Class D toxic. 


\section{WHC-EP-0480-1}

This page intentionally left blank. 


\subsection{SAMPLE ANALYSIS}

Both routine operations and potential upsets at the 222-S Laboratory and their respective effluent streams were reviewed. This review led to developing proposed sampling and analysis programs. In order to determine the liquid effluent sampling and analysis appropriate for the facility, the following methodology was used.

The normal operations of the facility were examined to identify routine processes. The various hazardous materials involved in the processes were identified and their potential for entering a liquid effluent stream was evaluated. Based on this evaluation, the potential components of the liquid effluent stream under normal operating conditions were identified.

To ensure that the sample analyses would also provide the necessary data for releases other than from normal operations, potential upset conditions were identified. The hazardous materials that could be introduced into the liquid effluent streams of the facility under these upset conditions were then identified.

The potential constituents of each liquid effluent stream that would result from both normal operations and upset conditions have been examined to determine the possible quantities that could be introduced into the liquid effluent stream. These constituents were examined in relation to analysis detection limits and regulatory release limits. Based on this, the potential liquid effluent constituents requiring analyses were identified. In cases where past and/or current data were available on liquid effluent sample analyses, those results were examined. Analytical procedures for hazardous constituents at levels significantly above minimum detection limits were added to the list of necessary analyses. If previous or current analyses indicated levels below minimum detection limits and if no potential upset condition could result in increased levels of the hazardous material, the need for the specific analysis was 97 iminated.

The examination of existing and potential liquid effluent streams from the 222-S Laboratory identified the need for two sampling and analys is programs. One program is for the 207-SL Retention Basins stream to the 216-S-26 Crib and the other is for the 222-SA Laboratory effluent stream to the 216-S-26 Crib. Also, the potential upset condition of an undetected disconnect at the 219-S Tanks Transfer Jumper was identified as requiring a sampling and analysis program, as necessary, if current knowledge regarding waste composition is deemed inadequate at the time of the spil1.

Currently the 222-S Laboratory is implementing a Sampling and Analysis Plan (WHC-SD-WM-EV-075) for the sampling and analysis of the 207-SL Retention Basins. Sampling of the basins is scheduled to start in FY 93 . This sampling effort will provide data to confirm waste designation, support development of wastewater treatment projects and groundwater contamination studies, and confirmatory data for WAC 173-240 Engineering Reports for Washington State Waste Discharge Permits. 


\subsection{The 222-S LABORATORY EFFLUENT STREAM}

The 222-S Laboratory effluent stream to the 207-SL Retention Basins and then to the 216-S-26 Crib should be routinely sampled and analyzed before discharge to the 216-S-26 Crib. The suggested analyses and frequency of sampling needed are:

Suggested Analysis

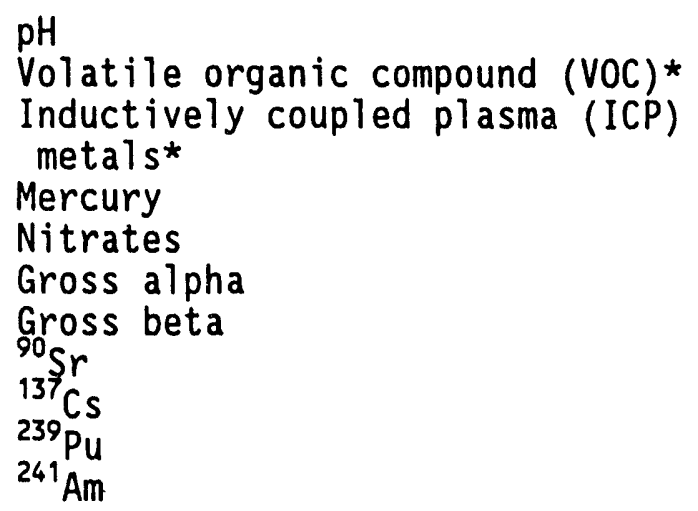

Suggested Frequency

Per batch

Per batch

Per batch

Per batch

Per batch

Per batch

Per batch

Quarterly

Quarterly

Quarterly

Quarterly

\subsection{The 222-SA LABORATORY EFFLUENT STREAM}

When the modification to route the 222-SA Laboratory liquid effluent to the 207-SL Basin is completed, the analyses necessary for the combined effluents before discharge to the 216-S-26 Crib will be:

$$
\begin{aligned}
& \text { Suggested Analysis } \\
& \text { pH } \\
& \text { VOC* } \\
& \text { ICP Metals* } \\
& \text { Mercury } \\
& \text { Nitrates } \\
& \text { Gross alpha } \\
& \text { Gross beta } \\
& { }_{90} \mathrm{Sr} \\
& { }_{137} \mathrm{Cs} \\
& { }^{239} \mathrm{Pu} \\
& { }^{241} \mathrm{Am}
\end{aligned}
$$

Suggested Frequency

Per batch

Per batch

Per batch

Per batch

Per batch

Per batch

Per batch

Quarterly

Quarterly

Quarterly

Quarterly

\subsection{9-S WASTE HANDLING FACILITY}

The identified potential upset resulting in discharge of 219-S waste need only be sampled if such an upset occurs. If the undetected disconnect should happen, the resultant effluent should be analyzed as discussed in the waste analysis plan for 219-S (Warwick 1992).

*See Table 9-1 for specific metals and Vocs. 
WHC-EP-0480-1

\subsection{SUMMARY}

Table 9-1 summarizes the individual samples required and a comparison of a typical estimated detection limit to the regulatory level required. Information regarding applicable procedures related to monitoring, calibration, and chain of custody is listed in Section 12.0.

The suggested Westinghouse Hanford procedures listed in Table 9-2 will have to be validated to ensure equivalency to EPA-, DOE-, and Ecology-approved procedures.

\subsubsection{U.S. Department of Energy Analytical and Laboratory Guidelines}

The analytical and laboratory procedures for the FEMP activities are identified in the Quality Assurance Project Plan for the Facility Effluent Monitoring Plan Activities (WHC 1991i). General requirements for laboratory procedures, data analyses, and statistical treatment are addressed in this Quality Assurance Project Plan (QAPjP).

The QA requirements are addressed in WHC-SD-CP-QAPP-003 (WHC 1990b), WHC-SD-CP-QAPP-001 (WHC 1989b, and WHC-SD-CP-QAPP-002 (WHC 1989f).

The FEMP QA requirements for sampling and analysis plans associated with the Liquid Effluent Study (LES) are identified in the latest revision of the Liquid Effluent Sampling Quality Assurance Project Plan, WHC-SD-WM-QAPP-011 (WHC 1991g).

The elements in Table 9-3 are identified in Environmental Regulatory Guide for Radiological Effluent Monitoring and Environmental Surveillance (DOE 1991). 
Table 9-1. Summary of Sample Analysis Requirements For Liquid Effluents.

\begin{tabular}{|c|c|c|c|c|}
\hline & $\begin{array}{c}\text { SW } 846^{\star} \text { / West inghouse } \\
\text { Hanford Company } \\
\text { procedure }\end{array}$ & $\begin{array}{l}\text { Typical } \\
\text { detection limit } \\
\text { SW } 846 \text { or } \\
\text { West inghouse } \\
\text { Hanford Company }\end{array}$ & $\begin{array}{c}\text { Regulatory } \\
\text { level }\end{array}$ & $\begin{array}{c}\text { Regulatory } \\
\text { bas is/guidance }\end{array}$ \\
\hline $\begin{array}{l}\text { Metals } \\
\text { Cadmium } \\
\text { Chromium (total) } \\
\text { Lead } \\
\text { Mercury } \\
\text { Silver }\end{array}$ & 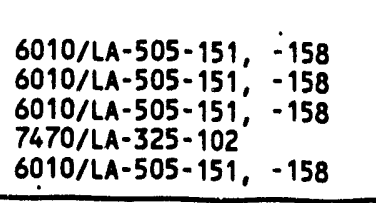 & $\begin{array}{l}0.02 \mathrm{p} / \mathrm{m} \\
0.05 \mathrm{p} / \mathrm{m} \\
0.30 \mathrm{p} / \mathrm{m} \\
0.05 \mathrm{p} / \mathrm{m} \\
0.30 \mathrm{p} / \mathrm{m}\end{array}$ & $\begin{array}{l}1.0 \mathrm{p} / \mathrm{m} \\
5.0 \mathrm{p} / \mathrm{m} \\
5.0 \mathrm{p} / \mathrm{m} \\
0.2 \mathrm{p} / \mathrm{m} \\
5.0 \mathrm{p} / \mathrm{m}\end{array}$ & $1,2,3$ \\
\hline $\begin{array}{l}\text { Volatile organics } \\
\text { Carbon tetrachloride } \\
\text { Chloroform } \\
\text { Tetrachloroethylene } \\
\text { Trichloroethylene } \\
\text { Chlorobenzene } \\
\text { Pyridine }\end{array}$ & $\begin{array}{l}8240 / N A \\
8240 / N A \\
8240 / N A \\
8240 / N A \\
8240 / N A \\
8240 / N A\end{array}$ & $\begin{array}{l}0.005 \mathrm{p} / \mathrm{m} \\
0.005 \mathrm{p} / \mathrm{m} \\
0.005 \mathrm{p} / \mathrm{m} \text { (est.) } \\
0.005 \mathrm{p} / \mathrm{m} \\
0.005 \mathrm{p} / \mathrm{m} \\
0.005 \mathrm{p} / \mathrm{m} \text { (est.) }\end{array}$ & $\begin{array}{l}0.05 \mathrm{p} / \mathrm{m} \\
6.0 \mathrm{p} / \mathrm{m} \\
0.079 \mathrm{p} / \mathrm{m} \\
0.5 \mathrm{p} / \mathrm{m} \\
0.15 \mathrm{p} / \mathrm{m} \\
1.12 \mathrm{p} / \mathrm{m}\end{array}$ & $\begin{array}{l}1,2,3 \\
1,2,3 \\
1,2,3 \\
1,2,3 \\
1,2,3 \\
1,2,3\end{array}$ \\
\hline Total organic carbon & $9060 / L A-344-105$ & $1.0 \mathrm{p} / \mathrm{m}$ & $100 \mathrm{p} / \mathrm{m}$ & 4 \\
\hline pH & $9040,9045 / L A-212-102$ & $1-14$ & $\begin{array}{r}<2.0 \\
>12.5\end{array}$ & $1,2,3,4,5$ \\
\hline Nitrate & EPA $300 / L A-533-105$ & $10 \mathrm{p} / \mathrm{m}$ & $100,000 \mathrm{p} / \mathrm{m}$ & 2 \\
\hline 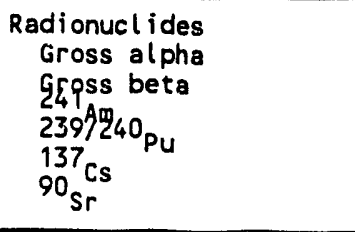 & $\begin{array}{l}9310 / L A-508-101 \\
9310 / L A-508-101 \\
\text { NA/LA-943-123 } \\
\text { NA/LA-943-123 } \\
\text { NA/LA-548-121 } \\
\text { NA/LA-220-104 }\end{array}$ & $\begin{array}{l}0.01 \mathrm{pCi} / \mathrm{mL} \\
0.035 \mathrm{pCi} / \mathrm{mL} \\
0.5 \mathrm{pCi} / \mathrm{mL} \\
0.5 \mathrm{pCi} / \mathrm{mL} \\
10.0 \mathrm{pCi} / \mathrm{mL} \\
1.0 \mathrm{pCi} / \mathrm{mL}\end{array}$ & $\begin{array}{l}0.30 \mathrm{pCi} / \mathrm{mL} \\
1.0 \mathrm{pCi} / \mathrm{mL} \\
0.03 \mathrm{pCi} / \mathrm{mL} \\
0.03 \mathrm{pCi} / \mathrm{mL} \\
3.0 \mathrm{pCi} / \mathrm{mL} \\
1.0 \mathrm{pCi} / \mathrm{mL}\end{array}$ & $\begin{array}{l}5 \\
5 \\
6 \\
6 \\
6 \\
6\end{array}$ \\
\hline
\end{tabular}

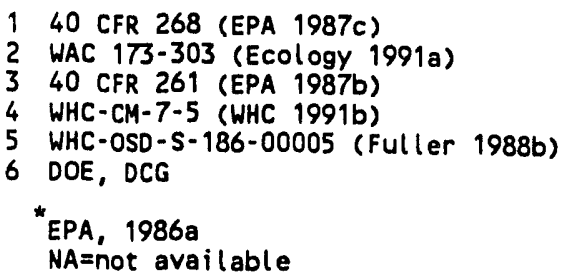


Table 9-2. Laboratory Procedures.

\begin{tabular}{|c|c|}
\hline Element & Documentation \\
\hline Sample identification system & To be provided when complete \\
\hline $\begin{array}{l}\text { Procedures preventing } \\
\text { crosscontamination }\end{array}$ & $\begin{array}{l}\text { Contained in 222-S Laboratory } \\
\text { Analytical Procedures [identified } \\
\text { in QAPJP WHC-EP-0446, Table 8-1 } \\
\text { (WHC 1991i)] }\end{array}$ \\
\hline Documentation of methods & $\begin{array}{l}\text { Contained in 222-S Laboratory } \\
\text { Analytical Procedures (identified } \\
\text { in QAPJP WHC-EP-0446 Table 8-1) }\end{array}$ \\
\hline Gamma emitting radionuclides & See QAPjP, Table 8-1 \\
\hline Calibration & See QAPjP, Table B-1 \\
\hline Handling of samples & See QAPjP, Table 8-1 \\
\hline $\begin{array}{l}\text { Analysis method and } \\
\text { capabilities }\end{array}$ & See QAPjP, Table 8-1 \\
\hline $\begin{array}{l}\text { Gross alpha, beta, and gamma } \\
\text { measurements }\end{array}$ & See QAPjP, Table 8-1 \\
\hline Direct gamma-ray spectrometry & See QAPjP, Table 8-1 \\
\hline Beta counters & See QAPjP, Tabie 8-1 \\
\hline Alpha-energy analysis & See QAPjP, Table 8-1 \\
\hline $\begin{array}{l}\text { Radiochemical separation } \\
\text { procedures }\end{array}$ & $\begin{array}{l}\text { LA } 508-113 \\
\text { LA } 943-123 \\
\text { LA } 548-121 \\
\text { LA } 220-104\end{array}$ \\
\hline Reporting of results & $\begin{array}{l}\text { L0-150-043 } \\
\text { L0-150-127 }\end{array}$ \\
\hline Counter calibration & See QAPjP, Table B-1 \\
\hline $\begin{array}{l}\text { Intercalibration of equipment } \\
\text { and procedures }\end{array}$ & $\begin{array}{l}L Q-508-002 \\
L Q-508-003 \\
L Q-508-005 \\
L Q-508-006\end{array}$ \\
\hline Counter background & $\begin{array}{l}\text { Contained in 222-S Laboratory } \\
\text { Analytical Procedures (QAPP, } \\
\text { Table 8-1) }\end{array}$ \\
\hline Quality assurance & $\begin{array}{l}\text { WHC-SD-CP-QAPP-001 } \\
\text { WHC-SD-CP-QAPP-002 } \\
\text { WHC-SD-CP-QAPP-003 }\end{array}$ \\
\hline
\end{tabular}

QAPjP=Quality Assurance Project Plan. 


\section{WHC-EP-0480-1}

Table 9-3. Data Analyses and Statistical Treatment.

\begin{tabular}{|c|c|}
\hline Element & Documentation \\
\hline $\begin{array}{l}\text { Summary of data and statistical } \\
\text { treatment requirements }\end{array}$ & WHC-SD-CP-QAPP-002 \\
\hline $\begin{array}{l}\text { Variability of effluent and } \\
\text { environmental data }\end{array}$ & $\begin{array}{l}\text { WHC-EP-0527 Environmental Releases } \\
\text { for Calendar Year } 1990\end{array}$ \\
\hline $\begin{array}{l}\text { Summarization of data and } \\
\text { testing for outliers }\end{array}$ & $\begin{array}{l}\text { Statistical identification of } \\
\text { control standards are performed by } \\
\text { the Laboratory Measurement Control } \\
\text { System (LMCS) data base program } \\
\text { during the annual review of data } \\
\text { for setting control limits. } \\
\text { Outliers are evaluated. }\end{array}$ \\
\hline $\begin{array}{l}\text { Treatment of significant } \\
\text { figures }\end{array}$ & WHC-SD-CP-QAPP-002 \\
\hline $\begin{array}{l}\text { Parent-decay product } \\
\text { relationships }\end{array}$ & $\begin{array}{l}\text { Parent-decay product relationships } \\
\text { are not accounted for in laboratory } \\
\text { operating procedures. }\end{array}$ \\
\hline $\begin{array}{l}\text { Comparisons to regulatory or } \\
\text { administrative control } \\
\text { standards and control data }\end{array}$ & $\begin{array}{l}\text { The 222-S Laboratory participates } \\
\text { in the EPA Intra Comparison } \\
\text { Program. }\end{array}$ \\
\hline Quality assurance & $\begin{array}{l}\text { WHC-SD-CP-QAPP-002 } \\
W H C-S D-C P-Q A P P-003\end{array}$ \\
\hline
\end{tabular}




\subsection{NOTIFICATION AND REPORTING REQUIREMENTS}

Notifications and reporting of specific events related to environmental releases and/or events involving effluents and/or hazardous materials will be made in accordance with DOE Orders 5400.1 (DOE 1988a) and 5000.3A (DOE 1990b). Implementation of the orders is accomplished by means of Hanford's Management Requirements and Procedures Manual (WHC 1989d). Specific implementation, where required, is included in the appropriate facility's occurrence categorization, notification and reporting procedure. Implementation of environmental limits and requirements is found in the Environmental Compliance Manual (WHC 1991b).

\subsection{REQUIREMENTS}

\subsubsection{0ccurrence Identification and Immediate Response}

Each employee will identify events and conditions and will promptly notify management of such occurrences.

- Call 811 if immediate help such as fire, ambulance, or patrol is required.

- Call 3-3800 (Patrol Operations Center) if assistance other than fire, ambulance, or patrol is required.

- After requesting necessary outside assistance, the employee will notify their supervisor, who will notify the facility manager, the building emergency director, and the Occurrence Notification Center at $6-2900$.

Operations personnel will take immediate action to stabilize or return the facility and/or operation to a safe condition.

The oversight organizations will notify their RL counterparts of the event after receiving notifications from and discussing the event with the facility manager.

\subsection{OCCURRENCE CATEGORIZATION}

Environmental occurrences will be categorized as soon as practical using the criteria for radioactive and hazardous materials release described in Sections 10.2 .1 and 10.2.2. These categorizations should be made within two hours of identification. 0ccurrences will be categorized by their seriousness. If categorization is not clear, the occurrence will be initially categorized at a level higher than that being considered. The occurrence categorization will then be either evaluated, maintained, or lowered as information becomes available. 
WHC-EP-0480-1

\subsubsection{Radioactive Release}

\subsubsection{Emergency}

- Any release of radioactive material to controlled or uncontrolled areas in concentrations that, if averaged over a period of $24 \mathrm{~h}$, would exceed 5,000 times the DCGs.

- Any release of radioactive material offsite that is not a normally monitored release and could reasonably be expected to result in an annual dose (or dose commitment to any member of the general population) greater than $500 \mathrm{mrem}$.

\subsubsection{Unusual Occurrence}

- A release of radioactive material that violates environmental requirements in permits, regulations, or DOE standards, as determined by Westinghouse Hanford Environmental Protection.

- Any other release below emergency levels that requires immediate reporting to regulatory agencies or triggers outside agency specific-action levels, as determined by Westinghouse Hanford Environmental Protection.

\subsubsection{Off-Normal Occurrence}

- Any release of radionuclides that is not a normally monitored release.

- Any discovery of radionuclides where they are not expected (e.g., storm sewers and sanitary sewers) and for which no immediate explanation is available.

- Any statistically significant increase in normally monitored releases of radionuclides to an uncontrolled area.

- Any release of radionuclides that will be reported to an outside agency (excluding normal reporting), but is not classified as an unusual occurrence.

- Any controlled and monitored gaseous radionuclide release exceeding a Westinghouse Hanford-established ACV on an annual basis or exceeding 10 times an ACV on a weekly basis.

- Any controlled and monitored (instantaneous) gaseous radionuclide release exceeding 5,000 times the DCG over any 4-h period. 
- Any controlled and monitored liquid radionuclide release exceeding a Westinghouse Hanford-established ACV on an annual basis or exceeding 2 times an ACV on a monthly or weekly basis.

- Any contro:ied and monitored liquid radionuclide release exceeding 5,000 times the DCG instantaneousiy.

\subsubsection{Hazardous Materials Release}

\subsubsection{Emergency}

- Any aciual or potential release of material to the environment that results in or could result in significant offsite consequences, (i.e., need to relocate people, major wildlife kills, woodland degradation, aquifer contamination, and the need to secure downstream water supply intakes).

\subsubsection{Unusual Occurrence}

- Release of a hazardous substance; a regulated pollutant; or an $0 i 1$ that exceeds an RQ, Federal permits, DOE standards, or levels requiring immediate reporting to outside agencies, as determined by the Westinghouse Hanford Environmantal Protection group.

\subsubsection{Off-Normal Occurrence}

- Any unmonitored release of a hazardous substance or regulated pollutant as determined by Westinghouse Hanford Environmental Protection.

- Any statistically significant increase of a hazardous substance in normally monitored releases.

- Any discovery of a toxic or hazardous substance where it is not expected.

- Any release of a hazardous substance or oil that is not classified as an unusual occurrence but will be reported to outside agencies (excluding normal reporting), as determined by Westinghouse Hanford Environmental Protection.

\subsubsection{Discovery of Radioactive or Hazardous Material}

Contamination Due to U.S. Department of

Energy Operations

\subsubsection{Emergency}

- Discovery of contamination that results or could result in significant consequences, (i.e., exceeding safe exposure limits to workers or the public). 


\subsubsection{Unusual Occurrence}

- Discovery of offsite contamination due to DOE operations that does not represent an immediate threat to the public.

- Any discovery of groundwater contamination not previously known or suspected.

\subsubsection{Off-Normal Occurrence}

- Discovery of any onsite contamination attributable to DOE operations not previously known or expected.

\subsubsection{Agreement and Compliance Activities}

\subsubsection{Unusual Occurrence}

- Any agreement, compliance, remediation, or permit-mandated activity for which notification has been received from the relevant regulatory agency that a site $\mathrm{plan}$ is not satisfactory or that a site is considered to be in noncompliance with schedules or requirements.

- Any occurrence under any agreement or compliance area that requires notification of an outside agency within $4 \mathrm{~h}$ or less, that triggers an outside regulatory agency action level, or that otherwise indicates specific interest or concern from such agencies.

\subsubsection{Off-Normal 0ccurrence}

- Any occurrence under any agreement or compliance area that will be reported to outside agencies in a format other than routine monthly or quarterly reports.

- Any changes to existing agreements or permit-mandated activities.

- Development of new agreements or permit-mandated activities. 
WHC-EP-0480-1

\subsection{INTERFACE WITH THE OPERATIONAL ENVIRONMENTAL SURVEILLANCE PROGRAM}

\subsection{DESCRIPTION}

The sitewide Environmental Monitoring Plan (EMP), as described in the FEMP Management Plan (WHC 1991h), consists of two distinct but related components: environmental surveillance conducted by PNL and effluent monitoring conducted by Westinghouse Hanford. The responsibilities for these two portions of the EMP are delineated in a Memorandum of Understanding (PNL 1989). Environmental surveillance, conducted by PNL, consists of surveillance of all environmental parameters to demonstrate compliance with regulations. Effluent monitoring includes both in-line and facility effluent monitoring as well as near-facility environmental monitoring. Projected EDEs, reported in this FEMP, are the products of in-line effluent monitoring. Nearfacility monitoring is required by Part 0, "Environmental Monitoring," Environmental Compliance Manual (WHC 1991b), and procedures are described in Operational Environmental Monitoring (WHC 1988b).

\subsection{PURPOSE}

The purpose of near-facility (operational environmental) monitoring is to determine the effectiveness of environmental controls in preventing unplanned spread of contamination from facilities and sites operated by Westinghouse Hanford for DOE. Effluent monitoring and reporting, monitoring of surplus and waste management units, and monitoring near-facility environmental media are conducted by Westinghouse Hanford for the purposes of: controlling operations, determining the effectiveness of facility effluent controls, measuring the adequacy of containment at waste transportation and disposal units, detecting and monitoring upset conditions, and evaluating and upgrading effluent monitoring capabilities.

\subsection{BASIS}

Near-facility operational environmental surveillance is conducted to (1) monitor employee protection; (2) monitor environmental protection; and (3) ensure compliance with local, State, and Federal regulations. Compliance with parts of DOE Orders 5400.1, General Environmental Protection Program (DOE 1988a); 5400.5, Radiation Protection of the Public and the Environment (DOE 1990a); 5484.1, Protection, Safety, and Health Protection Information Reporting System (DOE 1981); 5820.2A, Radioactive Waste Management (DOE 1990C); and DOE/EH-0173T, Environmental Regulatory Guide for Radiological Effluent Monitoring and Environmental Surveillance (DOE 1991), are addressed through this activity. 


\subsection{MEDIA SAMPLED AND ANALYSES PERFORMED}

Procedure protocols for sampling, analysis, data handling, and reporting are specified in WHC-CM-7-4 (WHC 1988b). Media include ambient air, surface water, groundwater, external radiation dose, soil, sediment, vegetation, and animals at or near active and inactive facilities and/or waste sites. Parameters monitored include the following, as needed: $\mathrm{pH}$, water temperature, radionuclides, radiation exposure, and hazardous constituents. Animals that are not contaminated, as determined by a field instrument survey, are released at the capture location.

\subsection{LOCATIONS}

Samples are collected from known or suspected effluent pathways (e.g., downwind of potential releases, liquid streams, or proximal to release points). To avoid duplication, Westinghouse Hanford relies upon existing sample locations where PNL had previously established sample sites (e.g., air samplers in the 300 Area). There are 38 air samplers ( 4 in the 100 Area and 34 in the 200/600 Areas), 35 surface water sample sites (22 in the 100 Area and 13 in the 200/600 Areas), 110 groundwater monitoring wells (20 in the 100 Area, 89 in the 200/600 Areas, and 1 in the 300/400 Areas), 299 external radiation monitor points [182 survey points and 41 thermoluminescent dosimetry (TLD) sites in the 100 Area, 61 TLD sites in the 200/600 Areas, and 15 TLD sites in the $300 / 400$ Areas], 157 soil sample sites ( 32 in the 100 Area, 110 in the 200/600 Areas, and 15 in the 300/400 Areas), and 95 vegetation sample sites (40 in the 100 Area, 40 in the 200/600 Areas, and 15 in the $300 / 400$ Areas). Animal samples are collected at or near facilities and/or waste sites. Specific locations of sample sites are found in WHC-CM-7-4 (WHC 1988b).

Additionally, surveys to detect surface radiological contamination, as scheduled in WHC-CM-7-4, are conducted near and on liquid waste disposal sites (e.g., cribs, trenches, drains, retention basin perimeters, pond perimeters, and ditch banks), solid waste disposal sites (e.g., burial grounds and trenches), unplanned release sites, tank farm perimeters, stabilized waste disposal sites, roads, and firebreaks in the operations Areas. There are 391 sites in the Operations Areas (100 in the 100 Area, 273 in the $200 / 600$ Areas, and 18 in the $300 / 400$ Areas) where radiological surveys are conducted.

\subsection{PROGRAM REVIEW}

The near-facility operational environmental monitoring program will be reviewed at least annually to determine that the appropriate effluents are being monitored and that the monitor locations are in position to best determine potential releases. 


\subsection{SAMPLER DESIGN}

Sampler design (e.g., air monitors) will be reviewed at least biannually to determine equipment efficiency and compliance with current EPA and industry (e.g., American National Standards Institute and American Society for Testing and Materials) standards.

\subsection{COMMUNICATION}

*- The Operations and Engineering Contractor and the Research and Development Contractcr will compare and communicate results of their respective monitoring programs at least quarterly and as soon as possible under upset conditions.

\subsection{REPORTS}

Results of the near-facility operational environmental monitoring program are published in WHC-EP-0145-3, Westinghouse Hanford Company Environmental

Surveillance Annual Report (Schmidt et al. 1990). The radionuclide values in this report are expressed in curies, or portions thereof, for each radionuclide per unit weight of sample (e.g., picocuries per gram) or in field instrument values (e.g., counts per minute) rather than EDE, which is calculated as the summation of the products of the dose equivalent received by specified tissues of the body and a tissue-specific weighting factor. 
WHC-EP-0480-1

This page intentionally left blank. 
WHC-EP-0480-1

\subsection{QUALITY ASSURANCE PROJECT PLAN}

\subsection{PURPOSE}

This QAPjP describes the quality assurance (QA) requirements associated with implementing FEMPs. The plan identifies the FEMP activities and assigns the appropriate QA requirements defined by WHC-CM-4-2 (WHC 1989e). This QAPjP will be consistent with the requirements in DOE 5700.6B, Quality Assurance (DOE 1986). In addition, QA requirements in 40 CFR 60, Appendix A, Reference Methodologies (EPA 1986b), will be considered when performing monitoring calculations and establishing monitoring systems.

\subsection{OBJECTIVE}

The objective of this plan is to provide a documented QAPJP describing QA requirements for facilities implementing the FEMPs.

\subsection{REQUIREMENTS}

A QAPJP (WHC 1991i) has been developed to implement the QA program requirements defined by WHC-CM-4-2 (WHC 1989e). The QAPjP applies specifically to the field activities, laboratory analyses, and continuous monitoring performed for all FEMPs and conducted by Westinghouse Hanford. Plans and procedures referenced in the QAPjP are available for regulatory review upon request by the direction of the Westinghouse Hanford Environmental Assurance Manager. Table 12-1 contains selected Westinghouse Hanford supporting procedures for FEMP activities, as described in the QAPJP. A point by point evaluation against the EPA method 114 regulations is included in Attachment 1.

The 222-S Laboratory on the Hanford Site has one program plan and two project plans to address applicable quality requirements related to sample analysis. These plans are as follows:

- WHC-SD-CP-QAPP-003, Quality Assurance Program Plan for the Chemical Analysis of Environmental Samples (WHC 1990b)

- WHC-SD-CP-QAPP-001, Analytical Chemistry Services Laboratories Quality Assurance Plan (WHC 1989b)

- WHC-SD-CP-QAPP-002, Quality Assurance Project Plan for the Chemical Analysis of Highly Radioactive Mixed Waste Samples in Support of Environmental Activities on the Hanford Site (WHC 1989f)

The RCRA protocol liquid effluent sampling, associated with the LES, is not part of the FEMPS. The QA requirements for the SAP associated with the LES are identified in the latest version of the LES QAPJP, WHC-SD-WM-QAPP-011 (WHC 1991g). 


\subsection{FACILITY-SPECIFIC REQUIREMENTS}

Table 12-2 lists facility-specific support procedures that are to be incorporated in FEMP-related activities. These procedures support the analytical procedures detailed in Sections 7.0 and 9.0.

The QAPJP also includes a list of analytes of interest and reference analytical methods for effluent monitoring at the Hanford Site. This list includes targeted detection limits and precision and accuracy requirements for each analyte. The analytes of interest applicable to the 222-S Laboratory Complex have been identified from this table in the QAPJP and are 1isted in Table 12-3 of this document. Procedures used in analyzing facility effluents should be equivalent to the referenced analytical methods 1 isted in Table 12-3.

The Method 114 comparisons for the stacks at the Hanford Site that are above the the NESHAPs criteria were conducted by $A$. K. Dasgupta at the 222-S Lab. The QA methods that address 40 CFR 61, Appendix B, Method 114, are addressed by the 222-S Lab in the point-by-point evaluations of the NESHAPs. These comparisons are contained in the following documents: WHC-EP-0541 (Kristofzski et al. 1992), WHC-EP-0542 (Crummel et al. 1992b), WHC-EP-0543 (Crummel et a1. 1992a), WHC-EP-0544 (Berneski et a1. 1992b), WHC-EP-0545 (Geiger et al. 1992), and WHC-EP-0547 (Berneski et al. 1992a). 
Table 12-1. Westinghouse Hanford Supporting Procedures for Facility Effluent Monitoring Plan Activities.

\begin{tabular}{|c|c|c|c|c|c|c|c|c|c|c|c|c|c|c|c|c|c|c|c|c|}
\hline 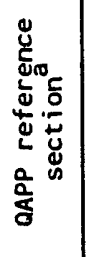 & $\begin{array}{l}\dot{j} \\
\dot{j} \\
\dot{v}\end{array}$ & $\underset{j}{m}$ & ְ̦ & 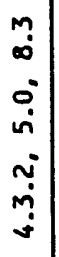 & $\begin{array}{c}\tilde{y} \\
\mathfrak{s} \\
\tilde{n} \\
\tilde{m} \\
\dot{v}\end{array}$ & $\begin{array}{l}0 \\
\text { in }\end{array}$ & 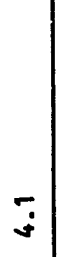 & $\mathfrak{g}$ & $\stackrel{0}{0}$ & : & $\begin{array}{l}\sim \\
\mathbf{\infty} \\
\mathbf{\infty}\end{array}$ & $\stackrel{\circ}{\circ}$ & $\stackrel{\circ}{-}$ & $\begin{array}{l}\dot{0} \\
\dot{j} \\
\dot{0} \\
i\end{array}$ & i & $\begin{array}{l}0 \\
\dot{m} \\
\dot{0}\end{array}$ & $\begin{array}{c}0 \\
a \\
0 \\
\dot{m} \\
\dot{0} \\
\dot{0}\end{array}$ & $\begin{array}{l}0 \\
0 \\
0\end{array}$ & $\dot{0}$ & \\
\hline 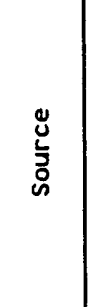 & 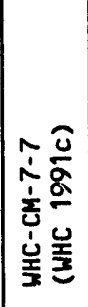 & 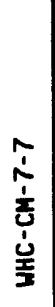 & 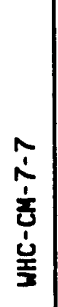 & 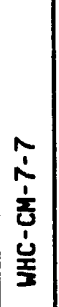 & $\begin{array}{l}\hat{1} \\
\hat{T} \\
\frac{1}{2} \\
\dot{1} \\
\frac{\hat{T}}{2}\end{array}$ & 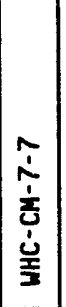 & $\begin{array}{l}\hat{i} \\
\frac{1}{2} \\
\frac{1}{1} \\
\dot{\underline{x}} \\
\underline{3}\end{array}$ & 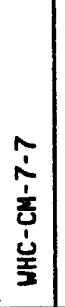 & 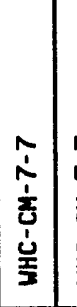 & \begin{tabular}{l|l}
$\hat{1}$ & \\
$\hat{1}$ & \\
$\frac{1}{2}$ & \\
$\dot{1}$ & \\
$\dot{1}$ &
\end{tabular} & & 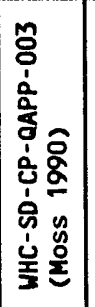 & 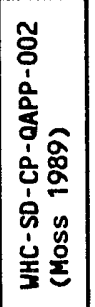 & 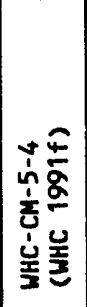 & 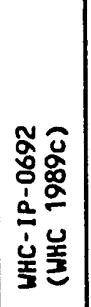 & 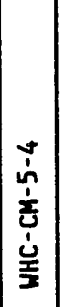 & 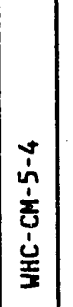 & 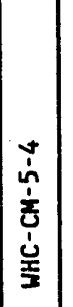 & 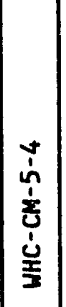 & 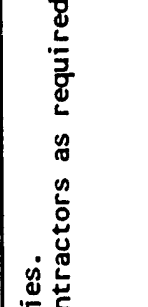 \\
\hline 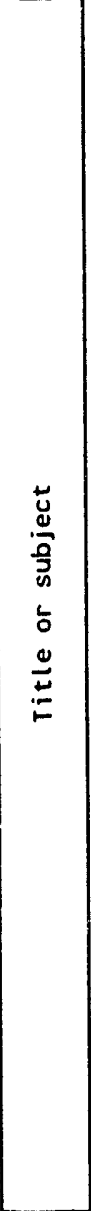 & 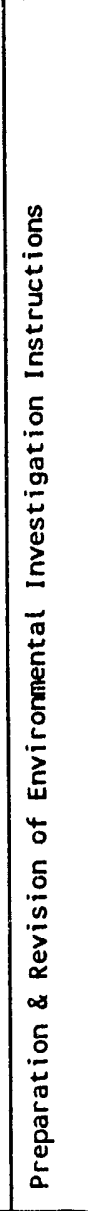 & 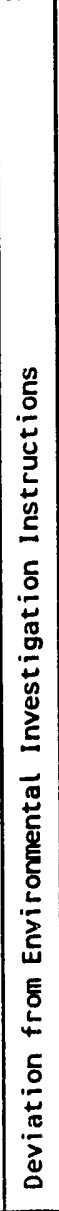 & 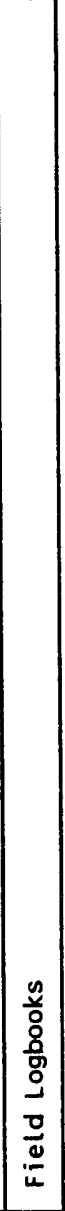 & 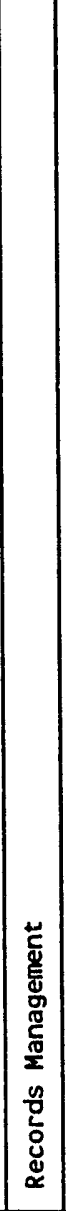 & 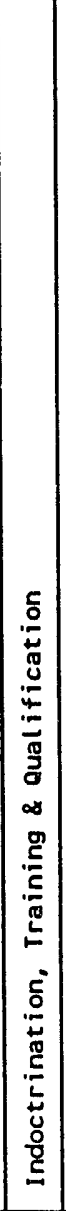 & 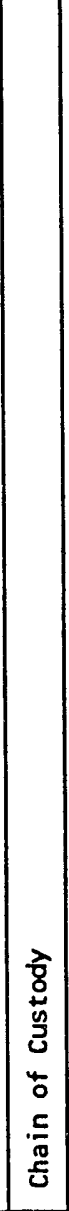 & 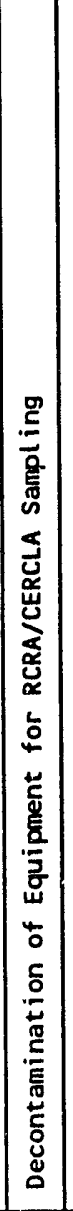 & 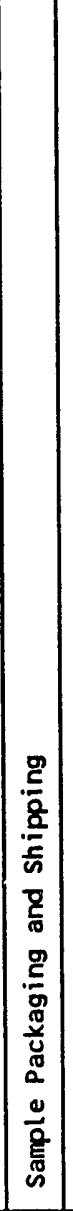 & 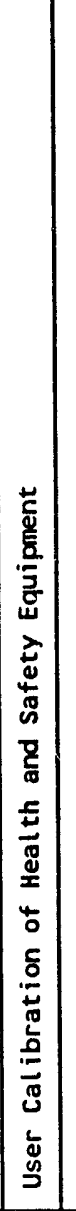 & 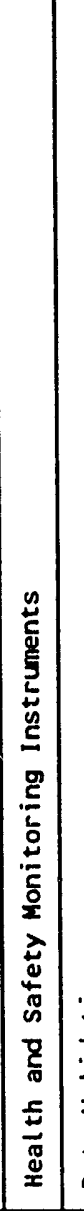 & 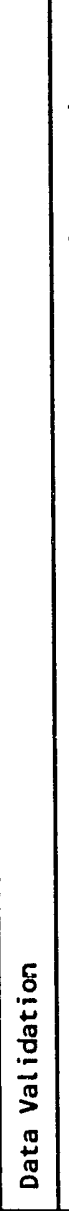 & 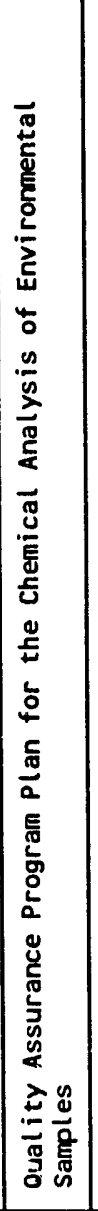 & 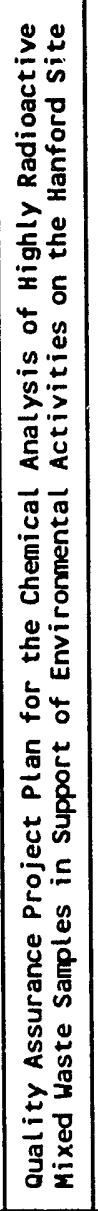 & 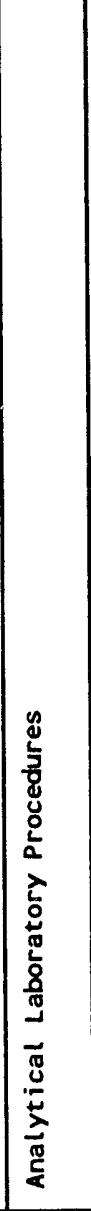 & 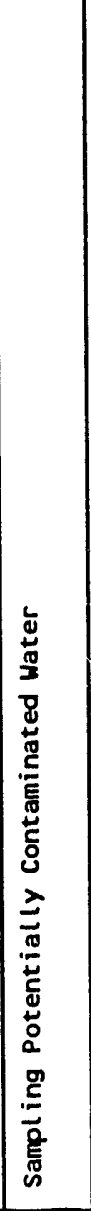 & 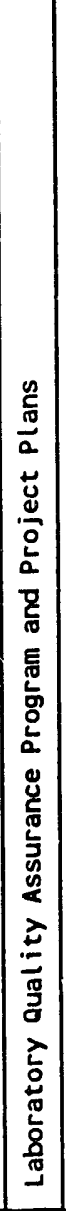 & 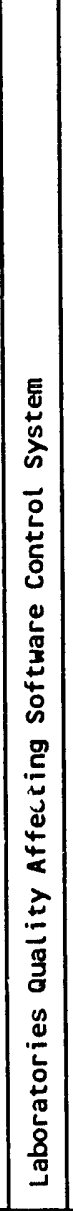 & 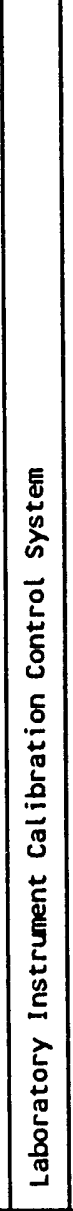 & 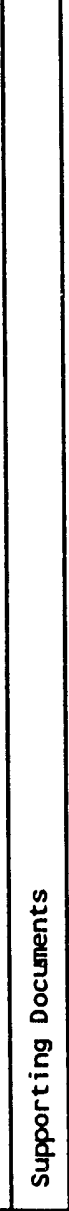 & 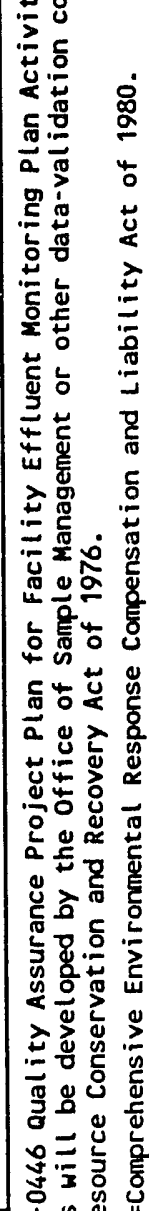 \\
\hline 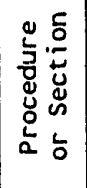 & $\begin{array}{l}\dddot{-} \\
\bar{z}\end{array}$ & $\begin{array}{l}\stackrel{\square}{\Xi} \\
\bar{z}\end{array}$ & $\begin{array}{l}\dddot{n} \\
\bar{z}\end{array}$ & $\mid$\begin{tabular}{l}
0 \\
\hdashline \\
$\bar{\omega}$
\end{tabular} & $\begin{array}{l}\tilde{-} \\
\bar{w}\end{array}$ & $\mid \begin{array}{l}\overline{\dot{n}} \\
\overline{\bar{w}}\end{array}$ & $\left|\begin{array}{l}n \\
n \\
z \\
\tilde{w}\end{array}\right|$ & $\left|\begin{array}{l}\bar{y} \\
\dot{v} \\
\bar{u}\end{array}\right|$ & $\begin{array}{c}\bar{m} \\
\bar{w}\end{array}$ & $\begin{array}{c}\tilde{n} \\
m \\
\bar{w}\end{array}$ & & $\$$ & $\underline{x}$ & $\bar{n}$ & $\stackrel{m}{n}$ & $\bar{\infty}$ & $\left|\begin{array}{c}m \\
\infty\end{array}\right|$ & $\tilde{\infty}$ & ñ & 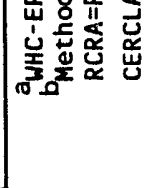 \\
\hline
\end{tabular}


Table 12-2. Supporting Documents and Procedures for 222-S Laboratory Complex Facility Effluent Monitoring Plan Activities.

\begin{tabular}{|l|l|l|}
\hline $\begin{array}{c}\text { Document or } \\
\text { procedure }\end{array}$ & \multicolumn{1}{|c|}{ Title or subject } & \multicolumn{1}{|c|}{$\begin{array}{c}\text { QAPjP section } \\
\text { reference }\end{array}$} \\
\hline L0-150-113 & Environmental Laboratory Operating Procedure & $2.0,5.0$ \\
\hline L0-090-101 & $\begin{array}{l}\text { Sample Receiving and Custodianship - } \\
222-S \text { Laboratory (Chain of Custody) }\end{array}$ & 5.0 \\
\hline L0-150-002 & $\begin{array}{l}\text { Responses to Off-Standard Condition Reports } \\
\text { and Precision Reports }\end{array}$ & $4.0,9.0$ \\
\hline L0-150-001 & $\begin{array}{l}\text { Laboratory Measurement Quality Control Using } \\
\text { the Laboratory Measurement Control System }\end{array}$ & $4.0,9.0,14.0$ \\
\hline L0-150-027 & Measurement Control & $4.0,9.0,14.0$ \\
\hline LQ-150-001 & Laboratory Measurement Quality Control & $4.0,9.0,14.0$ \\
\hline
\end{tabular}

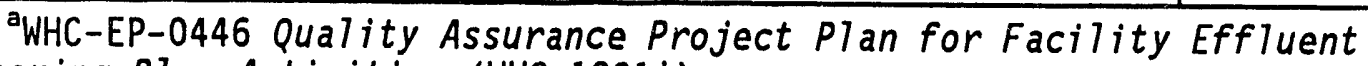
Monitoring Plan Activities (WHC 1991i). 
WHC-EP-0480-1

This page intentionally left blank. 


\subsection{INTERNAL AND EXTERNAL PLAN REVIEW}

The DOE Order 5400.1, General Environmental Protection Program, Chapter IV.4 (DOE 1988a) requires the FEMP be reviewed annually and updated every three years. The FEMP should be reviewed and updated, as necessary, after (1) each major change or modification in the facility processes, facility structure, ventilation and liquid collection systems, monitoring equipment, and/or waste treatment, or (2) a significant change to the safety analysis reports. In addition, EPA regulations require that records on the results of radioactive airborne emissions monitoring be maintained onsite for five years. Operations management will maintain records of reports on measurements of stack particulates or other nonradioactive hazardous pollutant emissions for three years.

On a semiannual basis, facility operators must certify that no changes in operations have occurred that would require new testing. Although the report is based on the CY, the emission limits apply to any period of 12 consecutive months. Westinghouse Hanford Environmental Protection prepares an annual effluent discharges report for each area on the Hanford Site, quantifying both airborne and liquid release pathways. In addition, a report on the air emissions and compliance to the Clean Air Act of 1977 (NESHAP) is prepared by Environmental Protection and submitted to EPA and DOE.

Facility management is to obtain Environmental Protection's approval for all changes to the FEMPs, including those generated in the annual review and update. In addition, the FEMP will be reviewed by Quality Assurance. 
WHC-EP-0480-1

This page intentionally left blank. 


\subsection{COMPLIANCE ASSESSMENT}

This section discusses the conclusions reached from evaluating existing or planned monitoring against regulatory requirements and/or guidance derived from DOE, Federal, and State regulations. The only effluent type for which a FEMP is required for the 222-S Laboratory Complex is the liquid.

\subsection{LIQUID EFFLUENTS GUIDANCE DERIVED FROM U.S. DEPARTMENT OF ENERGY, FEDERAL, AND STATE REGULATIONS}

\subsubsection{General}

As stated in DOE Order 5400.1, Preamble 8e (DOE 1988a), "Effluent monitoring is the collection and analysis of samples or direct measurement of liquid and gaseous effluents for the purpose of characterizing and quantifying contaminants, assessing radiation exposures of members of the public, providing a means to control effluents at or near the point of discharge and demonstrating compliance with applicable standards and permit requirements."

Further, it is stated that "DOE is committed to good environmental management of all its programs and at all its facilities to correct existing environmental problems, to minimize risks to the environment or public health and to anticipate and address potential environmental problems before they pose a threat to the quality of the environment or the public welfare." (DOE Order 5400.1, Preamble 5a)

The DOE has committed by means of DOE Orders 5484.1 (DOE 1981), 5000.3A (DOE 1990b), and the 5500 series dealing with emergency management to "...notify Headquarters [Emergency Operations Center] EOC of significant nonroutine releases of any pollutant or hazardous substance, e.g., releases of hazardous substances . . as required by the CERCLA." The actual amount of hazardous or radioactive substance that requires notification under CERCLA is found in 40 CFR 302 (EPA 1985a).

\subsubsection{Nonradioactive Liquids}

For liquid effluents discharged to cribs, the basic criterion is that facilities may not discharge any effluent that is a hazardous waste according to WAC 173-303. Washington Administrative Code 173-303 (Ecology 1991a) is the State's implementation of RCRA and incorporates, by reference, 40 CFR 261 (EPA 1987b) and 40 CFR 264 (EPA 1989b). The monitoring required is to demonstrate (1) a continuing knowledge of the waste composition and (2) compliance with the prohibition on discharging hazardous waste to the ground, as called for in DOE Order 5400.1, Sections 5 and 8 of Chapter IV (DOE 1988a).

A second area that impacts liquid releases to ponds, cribs, ditches, etc. is the "Land Ban" regulations embodied in 40 CFR 268 (EPA 1987c) and 
WAC 173-303-140 (Ecology 1991a). The 40 CFR 268 is incorporated by reference into WAC 173-303. Again, monitoring will be necessary to confirm the identity of the waste and demonstrate compliance.

While these regulations generally apply only to wastes designated as dangerous or those expected to be dangerous, the applicable DOE regulations (DOE Order 5400.1, 5.a 1-4) require monitoring to demonstrate verification of compliance, to evaluate effectiveness of effluent treatment, and to control and determine if a waste is hazardous. In addition, DOE has committed to maintaining the ability to address environmental discharges before they pose a threat to the quality of the environment or the public welfare.

Monitoring will provide facility data to demonstrate compliance with applicable regulations. If groundwater contamination is found, these data can possibly provide objective evidence that the contamination did not originate from a particular facility. The continued monitoring of liquid releases will serve to alert Westinghouse Hanford to potential problems in the effluents before significant groundwater contamination. In addition, a waste-analysis plan for interim facilities complies with WAC 173-303-300, WAC 173-303-400 and 40 CFR 265.13 (EPA 1980) to ensure that dangerous wastes will be adequately characterized before they are treated, stored, or disposed of within the Hanford Site boundaries.

One additional regulation that should be considered is WAC 173-216, State Waste Discharge Permit Program (Ecology 1990b). This regulation implements a State permit program for discharges of waste materials from industrial, commercial, and municipal operations into the ground and surface waters of the State.

This program is much like the NPDES program as required by the Clean Water Act of 1977 and is implemented by WAC 173-220 (Ecology 1990a). The regulations under WAC 173-216 (Ecology 1990b) establish a number of conditions that will be addressed in an issued permit. These include:

- Use of all known, available, and reasonable methods of prevention, control, and treatment (AKART)

- Pretreatment requirements

- Requirements pursuant to other laws, including as they apply to RCRA

- Conditions necessary to meet applicable water quality standards for surface waters or to preserve beneficial uses for groundwater

- Conditions necessary to prevent and control pollutant discharges from plant site runoff, spillage or leaks, sludge or waste disposal, or raw material storage

- Appropriate monitoring, reporting, and recordkeeping requirements

- Schedules of compliance. 
WHC-EP-0480-1

\subsubsection{Radioactive Liquids}

The DOE has maintained that the release of radioactive materials is governed by the Atomic Energy Act of 1954 and that the release limits set by DOE correspond to federally permitted releases and are thus exempt from other Federal and State regulations. At the same time, DOE has committed to complying with all "applicable" limits of EPA and State regulations.

The DOE Order 5400.5, Radiation Protection of the Public and the Environment (DOE 1990a), provides guidance on the acceptable levels of radioactivity allowed in liquid waste and effluents. The purpose of the DOE standards is to ensure that the dose to the public remains below $100 \mathrm{mrem}$ EDE per year (Chapter I.3) and to protect the natural resources.

Demonstration of compliance with DOE Order 5400.5 will generally be based on data from monitoring and surveillance programs (Chapter I, 8.a;

Chapter II, 6). It is stated in the DOE Order (Chapter II, 4.d) that liquid effluents from DOE activities will not cause private or public drinking water systems downstream of the facility discharge to exceed the drinking water limits in 40 CFR, Part 141, which are, in general, numerically equivalent to $4 \%$ of DOE DCG values. The drinking water limits also are addressed in Part $F$ of the Environmental Compliance Manual, WHC-CM-7-5 (WHC 1991b).

Guidance is provided in Chapter II, Section 3, for surface discharges.

- Discharges greater than DCG values on an annual average would require the BAT to be applied.

- Discharges at less than the DCG do not require implementation of BAT.

- The sertleable solids in any liquid effluent stream may not exceed $5 \mathrm{pCi} / \mathrm{g}$ alpha or $50 \mathrm{pCi} / \mathrm{g}$ beta.

- Interim dose limits for native aquatic animal organisms may not exceed one $\mathrm{rad} / \mathrm{d}$.

Guidance on discharges of liquid waste to aquifers and the phase out of soil columns is found in DOE Order 5400.5, Chapter II, 3.b. The guidance is limited to a reaffirmation of DOE commitment to phase out soil-column use (i.e., trenches, cribs, ponds, and drain fields) at the earliest practicable time. For those liquid discharges not first treated by BAT, DOE will develop (within 6 months of the issuance date of order) a plan and a schedule for implementing alternative, acceptable disposal at the earliest practicable time. In addition, new or increased discharges of radionuclides in liquid waste to soil columns are prohibited [Chapter II, 3.b(2)] unless the DOE activity cannot comply or the release is tritium [Chapter II, 3.e(1)]. 
Compliance with the dose limits of DOE Order 5400.5 (DOE 1990a) will be demonstrated by documentation of a combination of measurements and calculation (Chapter II, 6.a). The ALARA concept called for in DOE Order 5400.1 (DOE 1988a) has the objective of attaining dose levels as low as possible. Compliance with these two objectives would seem to require monitoring any stream that has the potential for containing measurable radioactivity. The DCGs are concentrations of radionuclides in water that, under continuous exposure (ingestion of water), would result in an EDE of $100 \mathrm{mrem} / \mathrm{yr}$ to the public. One method relating directly to the EDE of $100 \mathrm{mrem} / \mathrm{yr}$ would be to monitor to limits connected to some multiple or fraction of a DCG. That is the approach currently taken in Westinghouse Hanford's Environmental Compliance Manual (WHC 1991b). In lieu of any definitive DOE guidance, the contractor would appear to be free to choose any effluent limits desired within the general constraints of the $100 \mathrm{mrem} / \mathrm{yr}$-dose-limit and ALARA.

\subsection{COMPARISON OF CURRENT AND PLANNED LIQUID EFFLUENT MONITORING AGAINST REGULATORY COMPLIANCE}

The major regulatory criteria for the liquid effluent from 207-SL to the 216-S-26 Crib are (1) that a representative sample be obtained and (2) that the effluent batch can be demonstrated to be nonhazardous and nonradioactive (below DOE-approved limits). The major regulation that has to be satisfied is WAC 173-303, to ensure that no dangerous or hazardous waste is disposed of to the ground (Ecology 1991a). Satisfying WAC 173-303 will largely ensure that (1) EPA RQs 40 CFR 302 (EPA 1985a) are not exceeded and (2) the Land Ban Regulations of 40 CFR 268 (EPA 1987c) and WAC 173-303 are satisfied.

\subsubsection{The 207-SL Retention Basins}

Guidance from SW 846 (EPA 1986a), incorporated by reference into WAC 173-303 and from WAC 173-303-110 sampling methods, suggests a basin (by analogy to a pond) should be sampled from a number of surface points and vertical points (SW 846, Yol. II, Chapter 11). This is to eliminate the effects of heterogeneity due to temperature gradients, density gradients, or inadequate mixing.

Because the 207-SL retention basins are covered with concrete blocks, it is not feasible to obtain samples from various points. Currently the effluent to the basins is routed to a time and/or proportional sampling device that is currently set up to take a 150-ml sample for every $150 \mathrm{gal}$ of flow. The liquid sampler collects the sample portion in a refrigerated compartment that maintains a temperature of approximately $4{ }^{\circ} \mathrm{C}$. The sample is extracted from the effluent stream via a vacuum-sampling method. Analysis are run on the sample on a batch-by-batch basis.

The sample is extracted from the effluent stream via a vacuum-sampling method. This method of sampling is not appropriate for sampling volatile organic chemicals (VOC). Any sampling system that uses a pump to extract a liquid sample to analyze for volatile organic chemicals should use a positivedisplacement design to minimize potential for aerating and stripping volatile organics from the sample during removal from the basin effluent. In addition to the sampling system being inadequate for pulling VOC samples, the 
222-S Laboratory, at this time, has only one analyzer available for volatile organic samples. If this equipment is in use or is out of service due to repairs, then the release of the basin contents in a timely manner could be severely affected. Routine sampling currently analyzes for total organic carbons, this analysis is used as a warning device, and if found to be above plant limits, the batch will be held and sampled for volatile organics.

A more suitable grab-sampling device would be the weighted bottle type as described in SW 846, Vol. II, Chapter 9. This would allow a vertical stratified sampling plan to be used, ensuring more closely that the basin sample is representative.

The frequency of analysis (each batch before discharge to the crib) is appropriate.

\subsubsection{The 222-SA Laboratory}

The effluent is not sampled currently and thus does not comply with regulatory guidance. The effluent should be rerouted to the 207-SL Basins, (as is planned), and sampled according to internal procedures.

\subsubsection{The 219-S Waste Handling Facility}

Treatment tank 102 at the 219-S Waste Handling Facility is used to treat aqueous waste from the 222-S Analytical Laboratory before transfer to the DST system. The aqueous mixed waste is designated as a dangerous waste in accordance with WAC 173-303 (Ecology 1991a) for chacteristic waste (D002), toxicity characteristic waste (D004 through D011), spent halogenated solvents (F001 and F002), spent nonhalogenated solvents (F003 and F005), and state-oniy waste WTO1 (toxic extremely-hazardous waste).

In the event of an unplanned release, it might be necessary to confirm the identity of the specific spilled waste in order to adequately report the spill and help identify remedial actions. To provide compliance with DOE orders, the monitoring indicated for this stream would be to detect an unplanned release. Subsequent sampling and analys is actions would be determined if and when a release occurred. 
WHC-EP-0480-1

This page intentionally left blank. 


\subsection{SUMMARY AND CONCLUSIONS}

This FEMP assessed the magnitude of routine and potential liquid and airborne effluent releases from the 222-S Laboratory Complex to determine the compliance of effluent monitoring systems and sampling programs with applicable DOE, Federal, and State regulations. Based on the data reviewed, three effluent streams were determined to require monitoring according to the regulations. These three streams emanate from the 222-SA Wastewater, the 207-SL Retention Basins, and the 219-S Waste Transfer Jumper, respectively. The adequacy and compliance of the monitoring systems or sampling programs are documented in this FEMP. Specifics of the monitoring and sampling program determined not to be in compliance have been identified. 
WHC-EP-0480-1

This page intentionally left blank. 
WHC-EP-0480-1

\subsection{ATTACHMENTS}

\subsection{REFERENCES}

AEA, 1954, Atomic Energy Act of 1954, as amended, Public Law 83-703, 66 Stat. 919, 42 USC 2011.

American National Standards Institute (ANSI), 1969, American National Standard Guide to Sampling Airborne Radioactive Materials in Nuclear Facilities, ANSI N13.1-1969, New York, New York.

American National Standards Institute (ANSI), 1974, American National Standard Specification and Performance of On-Site Instrumentation for Continuously Monitoring Radioactivity in Effluents, ANSI N42.18-1974, New York, New York.

Beres, D. A., 1990, The Clean Air Act Assessment Package-1988 (CAP-88), A Dose and Risk Assessment Methodology for Radionuclide Emissions to Air, Vols 1-3, U.S. Environmental Protection Agency, Washington, D.C.

Berneski, L. D., A. K. Dasgupta, M. L. Clark, L. P. Diediker, 1992a, T Plant Comparison with 40 CFR 61, Subpart H, and Other Referenced Guidelines for Stack 291-T-1, WHC-EP-0547, Westinghouse Hanford company, Richland, Washington.

Berneski, M. R. Weiler, M. L. Clark, L. P. Diediker, 1992b, 340 Waste Handling Facility Comparison with 40 CFR 61, Subpart $H$, and Other Referenced Guidelines for Stack 340-NT-EX, WHC-EP-0544, Westinghouse Hanford Company, Richland, Washington.

Brown, M. J., R. K. P'Pool, and S. P. Thomas, 1990, Westinghouse Hanford Company Effluent Discharges and Solid Waste Management Report for Calendar Year 1989: 200/600 Areas, WHC-EP-0141-2, Westinghouse Hanford Company, Richland, Washington.

Clean Air Act of 1977,42 USC 7401 et seq.

Clean Water Act of 1977, 33 USC 1251 et seq.

Comprehensive Environmental Response, Compensation, and Liability Act of 1980 42 USC 9601 et seq.

Coony, F. M., D. B. Howe, and L. J. Voigt, 1988, Westinghouse Hanford Company Effluent Releases and Solid Waste Management Report for 1987: 200/600/1100 Areas, WHC-EP-0141, Westinghouse Hanford Company, Richland, Washington.

Coony, F. M. and S. P. Thomas, 1989, Westinghouse Hanford Company Effluent Discharges and Solid Waste Management Report for Calendar Year 1988: 200/600 Areas, WHC-EP-0141-1, Westinghouse Hanford Company, Richland, Washington. 
Crummel, G. M., A. K. Dasgupta, L. P. Diediker, 1992a, 241-AP Tank Exhaust Comparison with 40 CFR 61, Subpart $H$, and Other Referenced Guidelines for Stack 296-A-40, WHC-EP-0543, Westinghouse Hanford Company, Richland, Washington.

Crumme1, G. M., A. K. Dasgupta, L. P. Diediker, 1992b, 242-A Evaporator Comparison with 40 CFR 61 , Subpart $H$, and Other Referenced Guidelines for Stack 296-A-22, WHC-EP-0542, Westinghouse Hanford Company, Richland, Washington.

DOE, 1981, Environmental Protection, Safety, and Health Protection Information Reporting Requirements, DOE Order 5484.1, U.S. Department of Energy, Washington, D.C.

DOE, 1984, Environmental Protection, Safety, and Health Protection Standards, DOE Order 5480.4, U.S. Department of Energy, Washington, D.C.

DOE, 1986, Quality Assurance, DOE Order 5700.6B, U.S. Department of Energy, Washington, D.C.

DOE, 1988a, General Environmental Protection Program, DOE Order 5400.1, U.S. Department of Energy, Washington, D.C.

DOE, 1988b, Radiation Protection for Occupational Workers, DOE Order 5480.11, U.S. Department of Energy, Washington, D.C.

DOE, 1990a, Radiation Protection of the Public and the Environment, DOE Order 5400.5, U.S. Department of Energy, Washington, D.C.

DOE, 1990b, Occurrence Reporting and Processing of Operations Information, DOE Order 5000.3A, U.S. Department of Energy, Washington, D.C.

DOE, 1990C, Radioactive Waste Management, DOE Order 5820.2A, U.S. Department of Energy, Washington, D.C.

DOE, 1991, Environmental Regulatory Guide for Radiological Effluent Monitoring and Environmental Surveillance, DOE/EH-0173T, U.S. Depart.n.nt of Energy, Washington, D.C.

Ecology, 1990a, National Pc'?utant Discharge Elimination System Permit Program Washington Administrative Codes, Chapter 173-220, Washington State Department of Ecology, Olympia, Washington.

Ecology, 1990b, State Waste Discharge Permit Program, Washington Administrative Codes, Chapter 173-216, Washington State Department of Ecology, Olympia, Washington.

Ecology, 1990c, Underground Storage T:Ink Regulations, Washington Administrative Codes, WAC 173-360, Washington State Department of Ecology, Olympia, Washington.

Ecology, 1991a, Dangerous Waste Regulations, Washington Administrative Codes, Chapter 173-303, Washington State Department of Ecology, 01 ympia, Washington. 
Ecology, 1991b, General Regulations for Air Pollution Sources, Washington Administrative Codes, Chapter 173-400, Washington State Department of Ecology, 0lympia, Washington.

Ecology, EPA, and DOE, 1990, Hanford Federal Facility Agreement and Consent Order, Vo1. 1 and 2, Washington State Department of Ecology, U.S. Environmental Protection Agency, and U.S. Department of Energy, Olympia, Washington.

EPA, 1980, Standards for Owners and Operators of Hazardous Waste Treatment, Storage, and Disposal Facilities, Title 40, Code of Federal Regulations, Part 265, as amended, U.S. Environmental Protection Agency, Washington, D.C.

EPA, 1983, Health and Environmental Protection Standards for Uranium and Thorium Project Plans, Title 40, Code of Federal Regulations, Part 192, as amended, U.S. Environmental Protection Agency, Washington, D.C.

EPA, 1985a, EPA Designation, Reportable Quantities, and Notification Requirements for Hazardous Substances Under CERCLA, Title 40, Code of Federal Regulations, Part 302, as amended, U.S. Environmental Protection Agency, Washington, D.C.

EPA, 1985b, Environmental Radiation Protection Standards for the Management and Disposal of Spent Nuclear Fuel, High-Level and Transuranic Wastes, Title 40, Code of Federal Regulations, Part 191, as amended, U.S. Environmental Protection Agency, Washington, D.C.

EPA, 1985c, National Primary Drinking Water Regulations, Title 40, Code of Federal Regulations, Part 141, as amended, U.S. Environmental Protection Agency, Washington, D.C.

EPA, 1986a, Test Methods for Evaluating Solid Waste Physical/Chemical Methods, SW-846, U.S. Environmental Protection Agency, Washington, D.C.

EPA, 1986b, Standards of Performance for New Stationary Sources, Title 40, Code of Federal Regulations, Part 60, as amended, U.S. Environmental Protection Agency, Washington, D.C.

EPA, 1987a, National Emission Standards for Hazardous Air Pollutants (NESHAP) Title 40, Code of Federal Regulations Part 61, as amended, U.S. Environmental Protection Agency, Washington, D.C.

EPA, 1987b, Identification and Listing of Hazardous Waste, Title 40, Code of Federal Regulations, Part 261, U.S. Environmental Protection Agency, Washington, D.C.

EPA, 1987c, Land Disposal Restrictions, Title 40, Code of Federal Regulations, Part 268, as amended, U.S. Environmental Protection Agency, Washington, D.C.

EPA, 1989a, Approval and Promulgation of Implementation Plans, Title 40, Code of Federal Regulations, Part 52, as amended, U.S. Environmental Protection Agency, Washington, D.C. 
EPA, 1989b, Standards for Owners and Operators of Hazardous Waste Treatment, Storage, and Disposal Facilities, Title 40, Code of Federal Regulations, Part 264, as amended, U.S. Environmental Protection Agency, Washington, D.C.

EPA, 1990 "Subchapte: N--Effluent Guidelines and Standards, "Title 40, Code of Federal Regulaticns, Parts 401-471, U.S. Environmental Protection Agency, Washington, D.C.

EPA, 1991a, Technical Standards and Corrective Action Requirements for Owners and Operators of Underground Storage Tanks, Title 40, Code of Federal Regulations, Part 280, U.S. Environmental Protection Ageincy, Washington, D.C.

EPA, 1991b, Approval of State Underground Storage Tank Programs, Title 40, Code of Federal Regulations, Part 281, U.S. Environmental Protection Agency, Washington, D.C.

Fuller, R. K., 1988a, 219-S Waste Facility, WHC-OSD-S-186-00004, Westinghouse Hanford Company, Richland, Washington.

Fuller, R. K., 1988b, 222-S Waste Management Gaseous and Liquid Effluents, WHC-OSD-S-186-00005, Westinghouse Hanford Company, Richland, Washington.

Geiger, J. L., A. K. Dasgupta, M. L. Clark, L. P. Deidiker, 1992, Purex Plant Comparison with 40 CFR 61, Subpart $H$, and other Referenced Guidelines for Stack 291-A-1, WHC-EP-0545, Westinghouse Hanford Company, Richland, Washington.

Harris, M. D., and E. A. McNamar, 1987, Liquid Waste System for S-Plant, PFD-S-018-00001, Westinghouse Hanford Company, Richland, Washington.

ICF, 1989, 222-S Environmental Status as of August 28, 1989, Performed by ICF Technology for Westinghouse Hanford Company under Contract M-561244.

ICRP 1979, Limits for Intakes of Radionuclides by Workers, International Commission on Radiological Protection ICRP Publication 30, Pergamon Press, 0xford.

Kristofzski, J. G., A. K. Dasgupta, M. L. Clark, and L. P. Diediker, 1992, Plutonium Finishing Plant Comparison with 40 CFR 61 , Subpart $H$, and other Referenced Guidelines for Stack 291-Z-1, WHC-EP-0541, Westinghouse Hanford Company, Richland, Washington.

McNamar, E. A., and R. K. Fuller, 1986, Chemical Sewer Flowsheet for S-Plant Area, PFD-S-600-00001, By ZUTS Plants Process Engineering for

U.S. Department of Energy.

Manley, C. L., 1992, Evnironmental Releases for Calendar Year 1990, WHC-EP-0527, Westinghouse Hanford Company, Richland, Washington. 
Moore, R. E., C. F. Baes. III, L. M. McDowe1l-Boyer, A. P. Watson, F. 0. Hoffman, J. C. Pleasant, and C. W. Miller, 1979, AIRDOSE-EPA: A Computerize: Methodology for Estimating Environmental Concentrations and Dose to Man from Airborne Releases of Radionuclides, ORNL-5532, Oak Ridge National Laboratory, Oak Ridge, Tennessee, June 1979.

Moss, S. S., 1989, Quality Assurance Project Plan for the Chemical Analysis of Highly Radioactive Samples in Support of Environmental Activities on the Hanford Site, WHC-SD-CP-QAPP-002, Westinghouse Hanford Company, Richland, Washington.

Moss, S. S., 1990, Quality Assurance Program Plan the Chemical Anaiysis of Environmental Samples, WHC-SD-CP-QAPP-003, Westinghouse Hanford Company, Richland, Washington.

Napier, B. A., R. A. Peloquin, D. L. Strenge, and J. V. Ramsde11, 1988, GENII - The Hanford Environmental Radiation Dosimetry Software System, PNL-6584, Pacific Northwest Laboratory, Richland, Washington.

Nickels, J. M., 1991, Unit Dose Calculation Mehods and Summary of Facility Effluent Monitoring Plan Determinations, WHC-EP-0498, Westinghouse Hanford Company, Richland, Washington.

PNL, 1989, Memorandum of Understanding, Pacific Northwest Laboratory and Westinghouse Hanford Company, Richland, Washington.

RCW, 1945, Water Pollution Control Act of 1945, as amended, Revised Code of Washington 90.48 , 01ympia, Washington.

Resource Conservation and Recovery Act of 1976, 42 USC 6901 et seq.

Rhoads, K., 1990, Unit Dose Calculations for Westinghouse Hanford Company Facility Effluent Monitoring Plans, WHC-EP-0498, Westinghouse Hanford Company, Richland, Washington.

Rohay, V. J., 1990, Liquid Effluent Study Project Plan, WHC-EP-0275, Revision 2, Westinghouse Hanford Company, Richland, Washington.

S-Plant Operating Specification Documents, 1983-1988, OSD-S-186-00002 through00007 , Westinghouse Hanford Company, Richland, Washington.

Schmidt, J. W., C. R. Huckfeldt, A. R. Johnson, and S. M. McKinney, 1990, Westinghouse Hanford Company Environmental Surveillance Annual Report 200/600 Areas, Calendar Year 1989, WHC-EP-0145-3, Westinghouse Hanford Company, Richland, Washington.

Stordeur, R. T., 1990, Liquid Effluent Study Characterization Data, WHC-EP-0355, Westinghouse Hanford Company, Richland, Washington.

Superfund Amendments and Reauthorization Act of 1986, 42 USC 11001 et seq.

Warwick, G. J., 1991, 219-S Waste Treatment Facility Waste Analysis Plan, WHC-SD-WM-EV-058, Westinghouse Hanford Company, Richland, Washington. 
Warwick, G. J., 1992, 222-S Laboratory Complex Wastewater to 216-S-26 Crib Sampling and Analysis Plan, WHC-SD-WM-EV-075, Westinghouse Hanford Company, Richland, Washington.

WHC, 1988a, Management Policies, WHC-CM-1-1, as amended, Westinghouse Hanford Company, Richland, Washington.

WHC, 1988b, Operational Environmental Monitoring, WHC-CM-7-4, as amended, Westinghouse Hanford Company, Richland, Washington.

WHC, 1988c, Radiation Protection WHC-CM-4-10, as amended, Westinghouse Hanford Company, Richland, Washington.

WHC, 1989a, 222-5 Laboratory Facilities Hazards Identification and Evaluation, SD-CP-HIE-001, 1989, Westinghouse Hanford Company, Richland, Washington.

WHC, 1989b, Analytical Chemistry Services Laboratories Quality Assurance Plan, WHC-SD-CP-QAPP-001, Westinghouse Hanford Company, Richland, Washington.

WHC, 1989c, Health Physics Procedures Manual, WHC-IP-0692, Westinghouse Hanford Company, Richland, Washington.

WHC, 1989d, Management Requirements and Procedures Manual, WHC-CM-1-3, as amended, Westinghouse Hanford Company, Richland, Washington.

WHC, 1989e, Quality Assurance Manual, WHC-CM-4-2, Westinghouse Hanford Company., Richland, Washington.

WHC, 1989f, Quality Assurance Project Plan for the Chemical Analysis of Highly Radioactive Mixed Waste Samples in S!pport of Environment Activities on the Hanford Site, WHC-SD-CP-QAPP-002, Westinghouse Hanford Company, Richland, Washington.

WHC, 1990a, 222-S Laboratory Wastewater Stream-Specific Report, WHC-EP-0342, Addendum 13, Westinghouse Hanford Company, Richland, Washington.

WHC, 1990b, Quality Assurance Program Plan for the Chemical Analysis of Environmental Samples, WHC-SD-CP-QAPP-003, Westinghouse Hanford Company, Richland, Washington.

WHC, 1991a, A Guide For Preparing Hanford Facility Effluent Monitoring Plans, WHC-EP-0438, Science Applications International Corporation, Richland, Washington.

WHC, 1991b, Environmental Compliance Manual, WHC-CM-7-5, Westinghouse Hanford Company, Richland, Washington.

WHC, 1991c, Environmental Investigations and Site Characterization Manual, WHC-CM-7-7, Revision 2, Westinghouse Hanford Company, Rich1and, Washington.

WHC, 1991d, Facility Effluent Monitoring Plan Determinations for the 200 Area Facilities, WHC-EP-0440, Westinghouse Hanford Company, Richland, Washington. 
WHC, 199le, Functional Design Criteria 222-S Laboratory Waste Water Retention Facility, WHC-SD-W124-FDC-001, Rev. 0, Westinghouse Hanford Company, Richland, Washington.

WHC, 1991f, Laboratory Administration, WHC-CM-5-4, Westinghouse Hanford Company, Richland, Washington.

WHC, 1991g, Liquid Effluent Sampling Quality Assurance Project Plan, WHC-SD-WM-QAPP-011, Westinghouse Hanford Company, Richland, Washington.

WHC, 1991h, Management Plan for Facility Effluent Monitoring Plan Activities, WHC-EP-0491, Westinghouse Hanford Company, Richland, Washington.

WHC, 1991i, Quality Assurance Project Plan for Facility Effluent Monitoring Plan Activities, WHC-EP-0446, Westinghouse Harford Company, Richland, Washington. 
WHC-EP-0480-1

This page intentionally left blank. 
WHC-EP-0480-1

\section{DISTRIBUTION}

\section{Number of Copies}

OFFSITE

3

Westinghouse Idaho Nuclear Company
PO Box 4000
Idaho Falls, Idaho 83403

K. Kouri

$32-02$

\section{ONSITE}

6

U.S. Department of Energy

Field Office, Richland

G. M. Bell

A5-52

R. F. Brich

A5 -55

S. S. Clark

E. B. Dagan

S. D. Stites

A6-55

A5-15

Public Reading Room

A5-15

A $1-65$

1

Hanford Environmental Health Foundation

J. J. Maher

HI-53

2

Kaiser Engineers Hanford

B. J. Dixon

D. R. Pratt

G7-33

G7-33

9

Pacific Northwest Laboratory

W. J. Bjorklund

P7-68

T. D. Chikalla

P7 -75

R. E. Jaquish

D. L. Klages

J. K. Soldat

$\mathrm{K} 1-30$

P7-68

K3-54

A. K. Stalker

P7 -60

M. R. Weiler

R. K. Woodruff

Technical Files

P7-22

K6-13

$\mathrm{K} 1-11$

43

Westinghouse Hanford Company

M. L. Bell1

T6-16

T. L. Bennington

H4-16

R. J. Bliss

B3-04 
WHC-EP-0480-1

DISTRIBUTION (continued)

Number of Copies

ONSITE

Westinghouse Hanford Company (continued)

S. L. Brey

J. D. Briggs

G. D. Carpenter

L. P. Diediker (2)

J. J. Dorian

B. G. Erl andson

D. G. Farwick

T. P. Frazier (10)

D. W. Fritz

K. A. Gano

E. M. Greager

K. A. Hadley

E. J. Kosiancic

R. J. Landon

R. P. Marshall

J. M. Nickels (2)

M. K. Oldfield

L. W. Vance

G. E. Vansickle

G. J. Warwick (3)

D. J. Watson

Document Processing and Distribution (2)

T6-12

B4-52

H6-30

T1-30

H6-30

H6-20

H4-16

T1-30

H6-30

$\times 0-21$

H6-30

R3-56

T6-16

H6-22

T6-14

H6-22

R1-08

H4-16

H6-20

T6-12

X0-41

Central Files

L8-15
L8-04

Information Release Administration (3) R1-08 

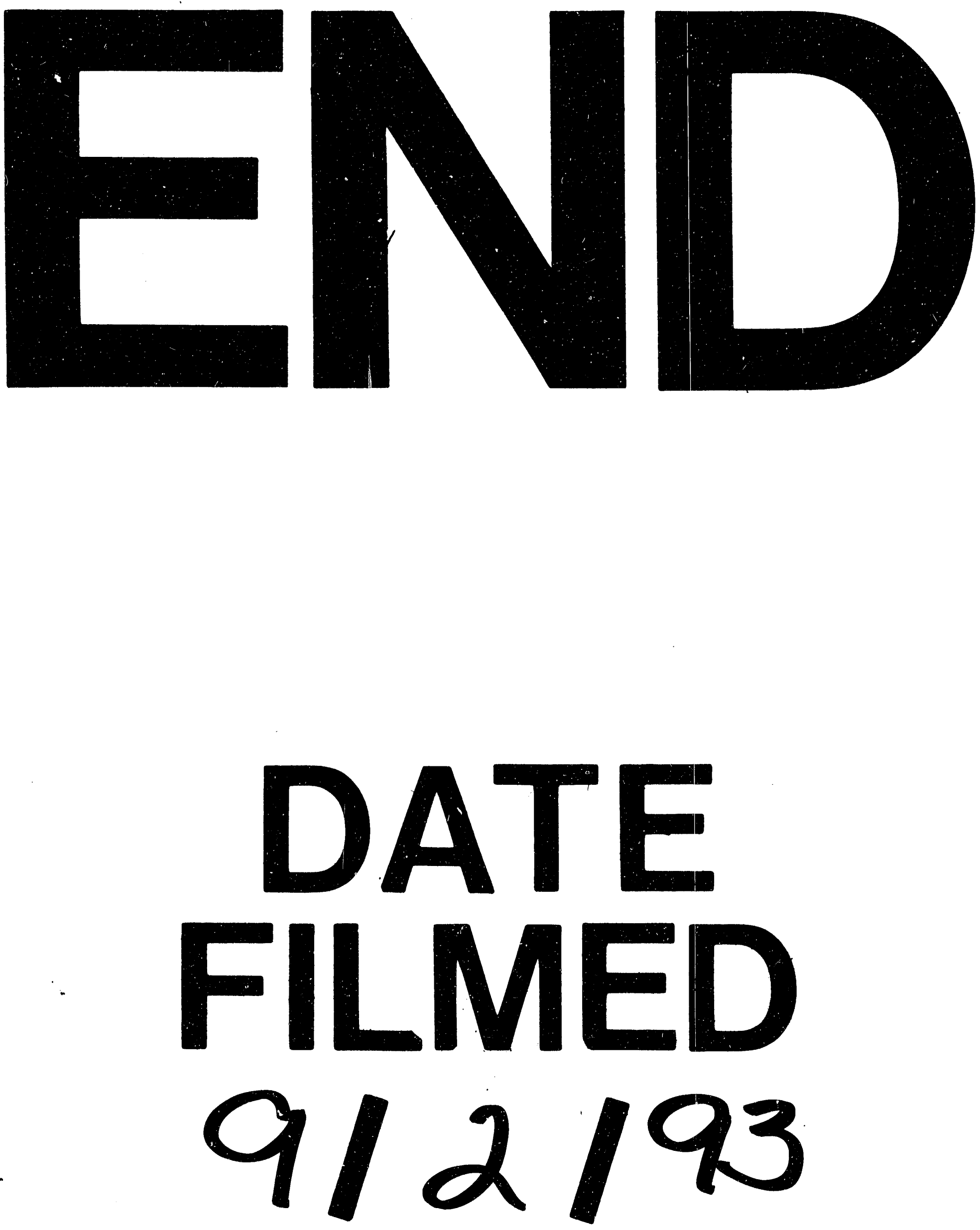


\section{'}

